Supporting Information

\title{
From Phenylthiazoles to Phenylpyrazoles: Broadening the Antibacterial Spectrum towards Carbapenem-Resistant Bacteria
}

Ali Hammad ${ }^{\mathrm{a} \perp}$, Nader S. Abutaleb ${ }^{\mathrm{b}}$, Mohamed M. Elsebaei $^{\mathrm{a}}$, Allison B. Norvil ${ }^{\mathrm{c}}$, Mohamed Alsawah $^{\mathrm{a}}$, Alsagher O. Ali ${ }^{\mathrm{b}, \mathrm{d}}$, Jelan A. Abdel-Aleem ${ }^{\mathrm{b}, \mathrm{e}}$, Abdelaziz Alattar ${ }^{\mathrm{f}}$, Samer A. Bayoumi $^{\mathrm{g}}$, Humaira Gowher ${ }^{\mathrm{c}, \mathrm{h}}$, Mohamed N. Seleem ${ }^{\mathrm{b}, \mathrm{i}^{* *}}$, and Abdelrahman S. Mayhoub ${ }^{\mathrm{a}, \mathrm{j}^{*}}$

a. Department of Pharmaceutical Organic Chemistry, College of Pharmacy, Al-Azhar University, Cairo 11884, Egypt

b. Department of Comparative Pathobiology, Purdue University, College of Veterinary Medicine, West Lafayette, IN 47907, USA

c. Department of Biochemistry, College of Agriculture, Purdue University, West Lafayette, IN 47907, USA

d. Division of infectious Diseases, Animal Medicine Department, Faculty of Veterinary Medicine, South Valley University, Qena, 83523, Egypt

e. Department of Industrial Pharmacy, Faculty of Pharmacy, Assiut University, Assiut, 71515, Egypt

f. Department of Analytical Chemistry, College of Pharmacy, Al-Azhar University, Cairo 11884, Egypt.

g. Department of Pharmaceutics, College of Pharmacy, Heliopolis University, Cairo, 11777, Egypt

h. $\quad$ Purdue University Center for Cancer Research, Purdue University, West Lafayette, IN 47907, USA

i.Purdue Institute for Inflammation, Immunology, and Infectious Diseases, West Lafayette, IN 47907, USA

j. University of Science and Technology, Nanoscience Program, Zewail City of Science and Technology, October Gardens, $6^{\text {th }}$ of October, Giza 12578, Egypt

\section{Corresponding Authors}

** MNS; email, mseleem@purdue.edu

*ASM; e-mail, amayhoub@azhar.edu.eg

$\perp$ : These authors contributed equally to this work 


\section{TABLE OF CONTENTS}

$\begin{array}{ll}\text { Figure 1S } & \text { S3 }\end{array}$

Table 1S $\quad$ S4

Table 2S S5-S8

$\begin{array}{ll}\text { Table 3S S8-S11 } & \text { S1 }\end{array}$

$\begin{array}{ll}\text { Figure 2S } & \text { S12 }\end{array}$

$\begin{array}{ll}\text { Figure 3S } & \text { S12 }\end{array}$

$\begin{array}{ll}\text { Figure 4S S13 } & \text { S13 }\end{array}$

$\begin{array}{ll}\text { Figure 5S } & \text { S14 }\end{array}$

$\begin{array}{ll}\text { Figure 6S } & \text { S17 }\end{array}$

$\begin{array}{ll}\text { Methods } & \text { S17-S20 }\end{array}$

Determination of the minimum inhibitory concentration (MIC) and minimum bactericidal concentration (MBC) against different Gram-positive and Gram-negative bacterial strains S17

$\begin{array}{ll}\text { Time-kill assay against MRSA } & \text { S18 }\end{array}$

In vitro cytotoxicity analysis against VERO cells and caco-2 cells $\quad$ S18

$\begin{array}{lr}\text { Pharmacokinetic assays } & \text { S19-20 }\end{array}$

$\begin{array}{ll}\text { Human Microsomal Stability Analysis } & \text { S19 }\end{array}$

$\begin{array}{ll}\text { Caco-2 Permeability Assay } & \text { S19 }\end{array}$

$\begin{array}{lr}\text { In vivo Pharmacokinetics } & \text { S20 }\end{array}$

$\begin{array}{ll}\text { Biochemical assays } & \text { S20 }\end{array}$

$\begin{array}{ll}\text { Protein purification } & \text { S20 }\end{array}$

$\begin{array}{ll}\text { Enzymatic inhibition assays } & \text { S21 }\end{array}$

${ }^{1} \mathrm{H}$ and ${ }^{13} \mathrm{C}$ NMR spectra of all compounds $\quad$ S22-S95

$\begin{array}{ll}\text { HPLC procedure } & \text { S96 }\end{array}$

$\begin{array}{ll}\text { HPLC chromatograms } & \text { S97-S110 }\end{array}$

$\begin{array}{ll}\text { References } & \text { S110-S111 }\end{array}$ 


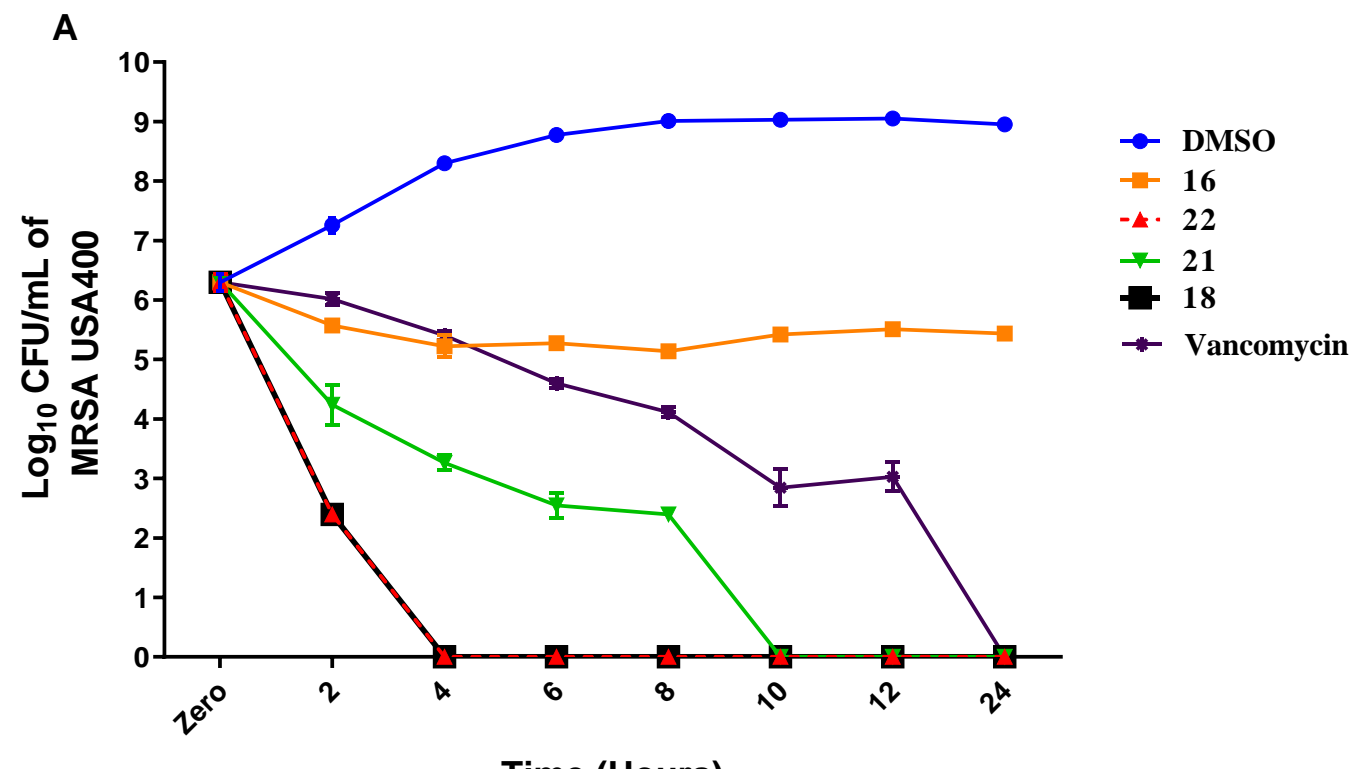

Time (Hours)

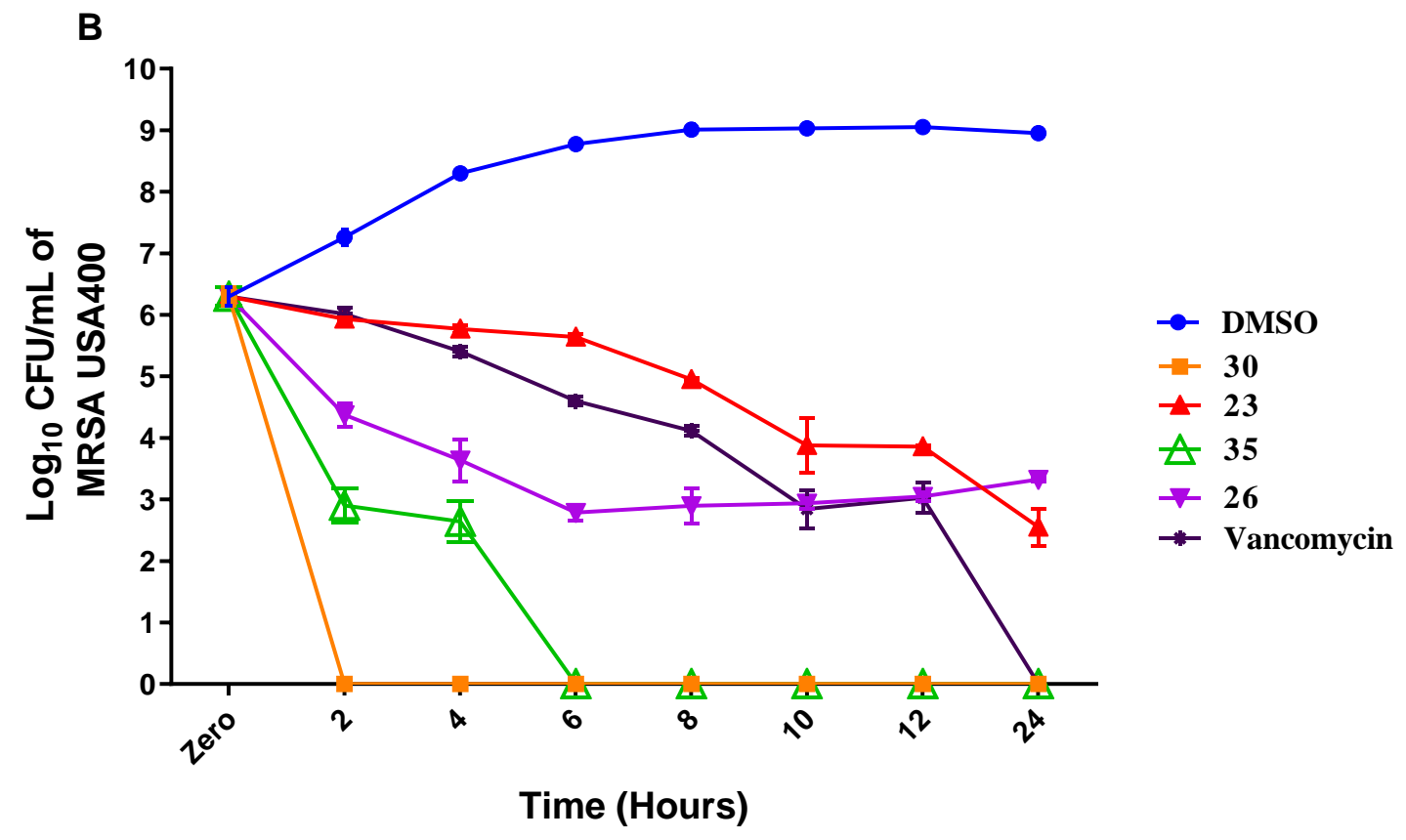

Figure 1S. Time-kill analysis of some phenylpyrazole compounds and vancomycin (at $5 \times$ MIC) against methicillin-resistant Staphylococcus aureus (MRSA USA400) over a 24 hours incubation period at $37^{\circ} \mathrm{C}$. DMSO (solvent for the compounds) served as a negative control. The error bars represent standard deviation values obtained from triplicate samples used for each compound/antibiotic studied. 
Table 1S. The minimum inhibitory concentration (MIC in $\mu \mathrm{g} / \mathrm{mL}$ ) and minimum bactericidal concentration ( $\mathrm{MBC}$ in $\mu \mathrm{g} / \mathrm{mL}$ ) of some phenylthiazoles against Gram-negative bacterial pathogens including Acinetobacter baumannii, Escherichia coli, Klebsiella pneumoniae, and Pseudomonas aeruginosa.

\begin{tabular}{|c|c|c|c|c|c|c|c|c|c|c|}
\hline & \multicolumn{10}{|c|}{ Bacterial Strains } \\
\hline \multirow[t]{2}{*}{$\begin{array}{l}\text { Compound* } \\
\text { /Antibiotic }\end{array}$} & \multicolumn{2}{|c|}{$\begin{array}{l}\text { Acinetobacter } \\
\text { baumannii } \\
\text { ATCC } 19606\end{array}$} & \multicolumn{2}{|c|}{$\begin{array}{l}\text { Escherichia } \\
\text { coli } \\
\text { BW25113 }^{1}\end{array}$} & \multicolumn{2}{|c|}{$\begin{array}{l}\text { Escherichia } \\
\text { coli } \\
\text { JW55031 }^{2}\end{array}$} & \multicolumn{2}{|c|}{$\begin{array}{l}\text { Klebsiella } \\
\text { pneumoniae } \\
\text { BAA-1706 }\end{array}$} & \multicolumn{2}{|c|}{$\begin{array}{l}\text { Pseudomonas } \\
\text { aeruginosa } \\
\text { ATCC } 15442\end{array}$} \\
\hline & MIC & MBC & MIC & MBC & MIC & MBC & MIC & MBC & MIC & MBC \\
\hline IS & $>128$ & $>128$ & $>128$ & $>128$ & 64 & $>128$ & N.D. $^{3}$ & N.D. ${ }^{3}$ & N.D. $^{3}$ & N.D. $^{3}$ \\
\hline IIS & 64 & $>128$ & $>128$ & $>128$ & 64 & $>128$ & $>128$ & $>128$ & $>128$ & $>128$ \\
\hline IIIS & 64 & $>128$ & $>128$ & $>128$ & 16 & 16 & $>128$ & $>128$ & $>128$ & $>128$ \\
\hline IVS & $>128$ & $>128$ & $>128$ & $>128$ & 64 & $>128$ & $>128$ & $>128$ & $>128$ & $>128$ \\
\hline VS & 64 & $>128$ & $>128$ & $>128$ & 32 & 32 & $>128$ & $>128$ & $>128$ & $>128$ \\
\hline VIS & 64 & 64 & $>128$ & $>128$ & 16 & 16 & $>128$ & $>128$ & $>128$ & $>128$ \\
\hline Colistin & $\leq 0.5$ & $\leq 0.5$ & $\leq 0.5$ & $\leq 0.5$ & $\leq 0.5$ & $\leq 0.5$ & $\leq 0.5$ & $\leq 0.5$ & 1 & 1 \\
\hline
\end{tabular}

${ }^{1}$ Wild-type strain

${ }^{2} \Delta$ tolC Mutant

${ }^{3}$ N.D. $=$ not determined

*Those compounds are all reported ${ }^{1}$ 
Table (2S): The strains used in the manuscript and their corresponding sites of isolation

\begin{tabular}{|c|c|}
\hline Bacterial strains & Isolation/Description \\
\hline $\begin{array}{l}\text { Methicillin-sensitive Staphylococcus aureus } \\
\text { ATCC } 6538\end{array}$ & $\begin{array}{l}\text { Quality control strain } \\
\text { Isolated from human lesion }\end{array}$ \\
\hline $\begin{array}{l}\text { Methicillin-sensitive Staphylococcus aureus } \\
\text { NRS } 107\end{array}$ & $\begin{array}{l}\text { Isolated in } 1991 \text { during an outbreak of } \\
\text { mupirocin-resistant S. aureus on a } \\
\text { dermatology ward of a university hospital } \\
\text { in Connecticut, USA. }\end{array}$ \\
\hline MRSA NRS 119 & $\begin{array}{l}\text { Isolated in } 2001 \text { from an } 85 \text {-year-old male } \\
\text { with dialysis-associated peritonitis in } \\
\text { Massachusetts, USA. }\end{array}$ \\
\hline MRSA NRS123 (USA400) & $\begin{array}{l}\text { Isolated from a human abscess in Michigan, } \\
2004 \text {. } \\
\text { It is a community associated methicillin- } \\
\text { resistant } S \text {. aureus (MRSA) strain } \\
\text { It is positive for the Panton-Valentine } \\
\text { leucocidin virulence factor and contains } \\
\text { staphylococcal chromosome cassette mec type } \\
\text { IV a. }\end{array}$ \\
\hline MRSA NRS 384 (USA300) & $\begin{array}{l}\text { Isolated from a wound in Mississippi, } \\
\text { USA. } \\
\text { It is a community-acquired methicillin- } \\
\text { resistant S. aureus (CA-MRSA) strain. }\end{array}$ \\
\hline MRSA NRS 385 (USA500) & $\begin{array}{l}\text { Isolated from a bloodstream sample in } \\
\text { Connecticut, USA. } \\
\text { It is a hospital-acquired methicillin-resistant } \\
\text { S. aureus (HA-MRSA) strain. } \\
\text { Resistant to erythromycin, clindamycin, } \\
\text { trimethoprim/sulfamethoxazole, } \\
\text { levofloxacin, gentamicin and tetracycline }\end{array}$ \\
\hline MRSA NRS 386 (USA700) & $\begin{array}{l}\text { Isolated from a bloodstream sample in } \\
\text { Louisiana, USA. } \\
\text { It is a methicillin-resistant S. aureus (MRSA) } \\
\text { strain. } \\
\text { Resistant to erythromycin }\end{array}$ \\
\hline VRSA 10 & $\begin{array}{l}\text { Isolated in } 2009 \text { from a plantar foot wound of } \\
\text { a 53-year-old female in Michigan, USA. }\end{array}$ \\
\hline VRSA 12 & Isolated from a foot wound \\
\hline $\begin{array}{llll}\text { Enterococcus faecalis } & \text { ATCC } & 51299 \\
\text { (VRE)3 } & & & \end{array}$ & $\begin{array}{l}\text { Isolated from peritoneal fluid, St. Louis, } \\
\text { MO } \\
\text { Quality control strain }\end{array}$ \\
\hline
\end{tabular}




\begin{tabular}{|c|c|}
\hline Bacterial strains & Isolation/Description \\
\hline $\begin{array}{l}\text { Enterococcus faecium ATCC } 700221 \\
\text { (VRE) }\end{array}$ & $\begin{array}{l}\text { Isolated from human feces, Connecticut, } \\
\text { USA } \\
\text { Quality control strain }\end{array}$ \\
\hline Listeria monocytogenes ATCC 19111 & $\begin{array}{l}\text { Isolated Poultry, England } \\
\text { Used for Media testing, Enteric Research, } \\
\text { Food testing } \\
\text { Antigenic Serotype } 1 / 2 \mathrm{a}\end{array}$ \\
\hline $\begin{array}{ll}\text { Cephalosporin-resistant } & \text { Streptococcus } \\
\text { pneumoniae ATCC } 51916 & \end{array}$ & $\begin{array}{l}\text { Isolated from from cerebrospinal fluid of } \\
\text { 13-month-old girl, Tennessee } \\
\text { Used for respiratory research }\end{array}$ \\
\hline $\begin{array}{ll}\text { Methicillin-resistant } & \text { Streptococcus } \\
\text { pneumoniae ATCC } 700677 & \end{array}$ & $\begin{array}{l}\text { Isolated from from Human patient, } \\
\text { Czechoslovakia, } 1987 \\
\text { Used for respiratory research } \\
\text { Serotype } 14\end{array}$ \\
\hline Clostridium difficile ATCC BAA 1870 & $\begin{array}{l}\text { Presence of binary toxin, tcdA and tcdB } \\
\text { genes. Toxinotype IIIb, Ribotype } 027\end{array}$ \\
\hline Acinetobacter baumannii ATCC 19606 & $\begin{array}{l}\text { Quality control strain isolated from urine } \\
\text { Used for Media testing, Quality control } \\
\text { strain for bioMérieux VITEK and } \\
\text { Sensititre products and Food testing }\end{array}$ \\
\hline Acinetobacter baumannii ATCC BAA 747 & $\begin{array}{l}\text { Quality control strain isolated from Human } \\
\text { clinical specimen - ear pus }\end{array}$ \\
\hline Acinetobacter baumannii NR 17786 & $\begin{array}{l}\text { Isolated on October 9,2006, from human } \\
\text { blood at the National Naval Medical Center in } \\
\text { Bethesda, Maryland, USA. } \\
\text { It is part of the "Genomic Sequencing of a } \\
\text { Diversity of U.S. Military Acinetobacter } \\
\text { baumannii-calcoaceticus Complex } \\
\text { Isolates" project to sequence the genomes } \\
\text { of clinical and environmental isolates of } \\
\text { medically relevant Acinetobacter spp. }\end{array}$ \\
\hline Acinetobacter baumannii NR 17785 & $\begin{array}{l}\text { A human isolate collected in June } 2006 \\
\text { from the wound of a patient at the National } \\
\text { Naval Medical Center in Bethesda, } \\
\text { Maryland, USA. } \\
\text { It is part of the "Genomic Sequencing of a } \\
\text { Diversity of US Military Acinetobacter } \\
\text { baumannii-calcoaceticus Complex } \\
\text { Isolates" project to sequence the genomes } \\
\text { of clinical and environmental isolates of } \\
\text { medically relevant Acinetobacter spp. }\end{array}$ \\
\hline Escherichia coli ATCC 25922 & $\begin{array}{l}\text { A clinical isolate } \\
\text { Quality control strain } \\
\text { Used for susceptibility testing and media } \\
\text { testing }\end{array}$ \\
\hline
\end{tabular}




\begin{tabular}{|c|c|}
\hline Bacterial strains & Isolation/Description \\
\hline & $\begin{array}{l}\text { Quality control strain for Abbott, API, } \\
\text { Autobac, BBL, bioMerieux Vitek, } \\
\text { Biosynth, Difco, IDS, Micro-Media, } \\
\text { MicroScan®, Roche Diagnostics, and } \\
\text { Sensititre products }\end{array}$ \\
\hline Escherichia coli ATCC 35150 & $\begin{array}{l}\text { Isolated from human faeces } \\
\text { Associated with hemorrhagic colitis } \\
\text { Serotype } 0157: \mathrm{H} 7\end{array}$ \\
\hline $\begin{array}{l}\text { Enterobacter cloacae subsp. cloacae ATCC } \\
\text { BAA-1143 }\end{array}$ & $\begin{array}{l}\text { Control strain } \\
\text { Derived from existing strain, } 1982\end{array}$ \\
\hline Klebsiella pneumoniae BAA-1706 & $\begin{array}{l}\text { Control strain } \\
\text { Used for Modified Hodge Test (HMT) } \\
\text { negative control designation }\end{array}$ \\
\hline Klebsiella pneumoniae BAA-1144 & $\begin{array}{l}\text { A human clinical specimen } \\
\text { Produces a low level of AmpC } \beta \text {-lactamase } \\
\text { Used as a control isolate for the AmpC disk } \\
\text { test and respiratory research }\end{array}$ \\
\hline Salmonella enterica $\mathrm{NR}-170$ & $\begin{array}{l}\text { Formerly Salmonella typhimurium, } \\
\text { Salmonella choleraesuis subsp. } \\
\text { choleraesuis subtype Typhimurium } \\
\text { Came from the Lister Institute of } \\
\text { Preventive Medicine in London, England. }\end{array}$ \\
\hline Salmonella enteritidis ATCC 13076 & $\begin{array}{l}\text { Used for media testing, enteric research, } \\
\text { emerging infectious disease research } \\
\text { Antigenic Properties: I 1,9,12:g,m:- } \\
\text { (determined by depositor) }\end{array}$ \\
\hline Salmonella enteritidis ATCC 14028 & $\begin{array}{l}\text { Isolated from tissue, animal - pools of heart } \\
\text { and liver from 4-week-old chickens } \\
\text { Used for media testing, preparatory test } \\
\text { control, enteric research, emerging infectious } \\
\text { disease research, pharmaceutical and personal } \\
\text { care and water testing }\end{array}$ \\
\hline Salmonella typhimurium ATCC 700720 & $\begin{array}{l}\text { Wild type strain isolated from a natural source } \\
\text { in } 1948 \\
\text { Used for emerging infectious disease research }\end{array}$ \\
\hline Shigella flexeneri ATCC 9199 & $\begin{array}{l}\text { A control strain used for enteric research and } \\
\text { emerging infectious disease research } \\
\text { Antigenic Properties: Serotype 1a }\end{array}$ \\
\hline Pseudomonas aeruginosa ATCC 9027 & $\begin{array}{l}\text { A quality control strain isolated from outer } \\
\text { ear infection }\end{array}$ \\
\hline
\end{tabular}




\begin{tabular}{|c|c|}
\hline Bacterial strains & Isolation/Description \\
\hline & $\begin{array}{l}\text { Used for assay of antimicrobial preservatives, } \\
\text { efficacy testing, media testing, preparatory } \\
\text { test control, sterility testing and } \\
\text { Pharmaceutical and Personal Care } \\
\text { Produces rhamnolipid surfactant }\end{array}$ \\
\hline Pseudomonas aeruginosa ATCC 25619 & $\begin{array}{l}\text { Used for assay of carbenicillin, assay of } \\
\text { vancomycin, opportunistic pathogen research } \\
\text { and pharmaceutical and personal care }\end{array}$ \\
\hline Pseudomonas aeruginosa ATCC 15442 & $\begin{array}{l}\text { A quality control strain isolated from animal } \\
\text { room water bottle } \\
\text { Used for Assay of antimicrobial preservatives, } \\
\text { Bacterial resistance testing textiles, Efficacy } \\
\text { testing, Testing antimicrobial agent, } \\
\text { antimicrobial handwashing formulations, } \\
\text { disinfectants, slimicides, bactericides, } \\
\text { Opportunistic pathogen research and } \\
\text { Pharmaceutical and Personal Care } \\
\text { A Quality control strain for Biosynthetic } \\
\text { products and Food testing }\end{array}$ \\
\hline Escherichia coli ATCC BAA 2452 & $\begin{array}{l}\text { NDM-1 positive strain isolated in Pakistan } \\
\text { Used for Multi-drug testing, Enteric research } \\
\text { and a Quality control strain for chromID } \\
\text { Carba medium } \\
\text { blaNDM positive by PCR } \\
\text { Carbapenem resistant (Imipenem and } \\
\text { Ertapenem resistant) }\end{array}$ \\
\hline Escherichia coli ATCC BAA 2469 & $\begin{array}{l}\text { NDM-1 positive strain isolated from human } \\
\text { urine } \\
\text { Used for Multi-drug testing and Enteric } \\
\text { research } \\
\text { blaKPC negative by PCR } \\
\text { blaNDM positive by PCR } \\
\text { Carbepenem-resistant (Imipenem and } \\
\text { Ertapenem) }\end{array}$ \\
\hline Klebsiella pneumoniae ATTC BAA 1705 & $\begin{array}{l}\text { KPC positive strain used for multidrug } \\
\text { resistance testing and respiratory research } \\
\text { Modified Hodge Test (MHT) positive control } \\
\text { designation } \\
\text { blaKPC positive by PCR } \\
\text { Carbapenem-resistant (Imipenem and } \\
\text { Ertapenem) }\end{array}$ \\
\hline Klebsiella pneumoniae ATTC BAA 2146 & $\begin{array}{l}\text { New Delhi metallo-beta-lactamase (NDM-1) } \\
\text { positive positive strain used for multidrug } \\
\text { resistance testing and respiratory research } \\
\text { Isolated from human urine }\end{array}$ \\
\hline
\end{tabular}




\begin{tabular}{|l|l|}
\hline Bacterial strains & Isolation/Description \\
\hline & blaKPC negative by PCR \\
& blaNDM positive by PCR \\
& Carbapenem-resistant (Imipenem and \\
& Ertapenem) \\
\hline Acinetobacter baumannii ATCC BAA 1605 & $\begin{array}{l}\text { Isolated from sputum of military personnel } \\
\text { returning from Afghanistan entering a }\end{array}$ \\
& Canadian hospital, June 30, 2006 \\
& Resistant to Ceftazidime, Gentamicin, \\
& Ticarcillin, Piperacillin, Aztreonam, \\
& Cefepime, Ciprofloxacin, Imipenem, and \\
& Meropemem. \\
& Sensitive to Amikacin and Tobramycin \\
\hline Pseudomonas aeruginosa ATCC 1744 & A quality control drug resistant clinical \\
& isolate \\
\hline
\end{tabular}

Table 3S. Minimum bactericidal concentrations (MBCs in $\mu \mathrm{g} / \mathrm{mL}$ ) of phenylpyrazoles and control antibiotics (linezolid, vancomycin, gentamicin, imipenem and meropenem) against the bacterial strains used in this manuscript

\begin{tabular}{|l|l|l|l|l|l|l|l|l|l|l|l|c|c|}
\hline \multirow{2}{*}{$\begin{array}{l}\text { Bacterial } \\
\text { Strains }\end{array}$} & \multicolumn{9}{|c|}{ Compounds/ Control antibiotics } \\
\cline { 2 - 13 } & $\mathbf{1 6}$ & $\mathbf{1 8}$ & $\mathbf{2 1}$ & $\mathbf{2 2}$ & $\mathbf{2 3}$ & $\mathbf{2 6}$ & $\mathbf{3 0}$ & $\mathbf{3 5}$ & Lin & Van & Gen & Imp & Mer \\
\hline $\begin{array}{l}\text { Staphylococcus } \\
\text { aureus } \\
\text { ATCC 6538 }\end{array}$ & 2 & 8 & 8 & 2 & 1 & 2 & 2 & 4 & 16 & 1 & NT & NT & NT \\
\hline $\begin{array}{l}\text { Staphylococcus } \\
\text { aureus } \\
\text { NRS107 }\end{array}$ & 4 & 4 & 2 & 2 & 1 & 4 & 4 & 2 & 16 & 2 & NT & NT & NT \\
\hline $\begin{array}{l}\text { Linezolid- } \\
\text { resistant MRSA } \\
\text { NRS119 }\end{array}$ & 4 & 2 & 2 & 1 & 1 & 2 & 8 & 8 & $>64$ & 1 & NT & NT & NT \\
\hline $\begin{array}{l}\text { MRSA } \\
\text { NRS123 } \\
\text { (USA400) }\end{array}$ & 4 & 8 & 8 & 2 & 8 & 2 & 4 & 8 & 32 & 1 & NT & NT & NT \\
\hline $\begin{array}{l}\text { MRSA } \\
\text { NRS384 } \\
\text { (USA300) }\end{array}$ & 4 & 2 & 4 & 1 & 1 & 2 & 2 & 4 & 32 & 1 & NT & NT & NT \\
\hline $\begin{array}{l}\text { MRSA } \\
\begin{array}{l}\text { NRS385 } \\
\text { (USA500) }\end{array}\end{array}$ & 2 & 2 & 8 & 1 & 0.5 & 2 & 2 & 4 & 16 & 1 & NT & NT & NT \\
\hline $\begin{array}{l}\text { MRSA NRS386 } \\
\text { (USA700) }\end{array}$ & 4 & 8 & 8 & 4 & 4 & 8 & 4 & 4 & 64 & 2 & NT & NT & NT \\
\hline VRSA10 & 4 & 4 & 4 & 2 & 1 & 2 & 4 & 8 & 64 & $>64$ & NT & NT & NT \\
\hline VRSA12 & 2 & 4 & 4 & 2 & 2 & 2 & 4 & 8 & 64 & 64 & NT & NT & NT \\
\hline $\begin{array}{l}\text { Staphylococcus } \\
\text { epidermidis } \\
\text { NRS 101 }\end{array}$ & 4 & 2 & 2 & 2 & 1 & 4 & 2 & 4 & 8 & 1 & NT & NT & NT \\
\hline $\begin{array}{l}\text { Enterococcus } \\
\text { faecalis ATCC } \\
\text { 51299 (VRE) }\end{array}$ & 4 & 2 & 2 & 1 & 0.5 & 2 & 4 & 8 & 32 & 64 & NT & NT & NT \\
\hline
\end{tabular}




\begin{tabular}{|c|c|c|c|c|c|c|c|c|c|c|c|c|c|}
\hline $\begin{array}{l}\text { Enterococcus } \\
\text { faecium ATCC } \\
700221 \\
\text { (VRE) } \\
\end{array}$ & 8 & 4 & 2 & 2 & 4 & 2 & 2 & 4 & 16 & $>64$ & NT & NT & NT \\
\hline $\begin{array}{l}\text { Listeria } \\
\text { monocytogenes } \\
\text { ATCC } 19111\end{array}$ & 8 & 4 & 4 & 4 & 1 & 2 & 2 & 16 & 64 & 2 & NT & NT & NT \\
\hline $\begin{array}{l}\text { Cephalosporin- } \\
\text { resistant } \\
\text { Streptococcus } \\
\text { pneumoniae } \\
\text { ATCC 51916 } \\
\end{array}$ & 4 & 2 & 2 & 2 & 2 & 4 & 4 & 16 & 32 & 2 & NT & NT & NT \\
\hline $\begin{array}{l}\text { Methicillin- } \\
\text { resistant } \\
\text { Streptococcus } \\
\text { pneumoniae } \\
\text { ATCC } 700677 \\
\end{array}$ & 4 & 2 & 2 & 2 & 0.5 & 2 & 2 & 8 & 16 & 2 & NT & NT & NT \\
\hline $\begin{array}{l}\text { Clostridium } \\
\text { difficile ATCC } \\
\text { BAA 1870 }\end{array}$ & $\mathrm{NT}^{2}$ & $\mathrm{NT}$ & $\mathrm{NT}$ & NT & NT & NT & NT & $\begin{array}{l}\mathrm{N} \\
\mathrm{T}\end{array}$ & NT & NT & NT & NT & NT \\
\hline $\begin{array}{l}\text { Acinetobacter } \\
\text { baumannii } \\
\text { ATCC } 19606\end{array}$ & 8 & 4 & 4 & 4 & 4 & 4 & 8 & 32 & 16 & NT & 8 & NT & NT \\
\hline $\begin{array}{l}\text { Acinetobacter } \\
\text { baumannii } \\
\text { ATCC BAA } \\
1141 \\
\end{array}$ & 8 & 4 & 4 & 4 & 4 & 8 & $>128$ & 32 & 4 & NT & 8 & NT & NT \\
\hline $\begin{array}{l}\text { Acinetobacter } \\
\text { baumannii } \\
\text { ATCC BAA } \\
1747\end{array}$ & 8 & 4 & 4 & 4 & 4 & 16 & $>128$ & 32 & 0.5 & NT & 8 & NT & NT \\
\hline $\begin{array}{l}\text { Acinetobacter } \\
\text { baumannii } \\
\text { NR } 17786\end{array}$ & 16 & 16 & 8 & 8 & 16 & 32 & $>128$ & 16 & $>64$ & NT & 16 & NT & NT \\
\hline $\begin{array}{l}\text { Acinetobacter } \\
\text { baumannii } \\
\text { NR } 17785\end{array}$ & 16 & 16 & 16 & 8 & 4 & 16 & $>128$ & 16 & $>64$ & NT & 16 & NT & NT \\
\hline $\begin{array}{l}\text { Escherichia coli } \\
\text { BW25113 }^{1}\end{array}$ & 8 & 8 & 4 & 8 & 16 & 8 & $>128$ & 64 & 0.5 & NT & 8 & NT & NT \\
\hline $\begin{array}{l}\text { Escherichia } \\
\text { coli } \\
\text { ATCC } 25922 \\
\end{array}$ & 8 & 8 & 4 & 4 & 4 & 8 & $>128$ & 32 & 1 & NT & 8 & NT & NT \\
\hline $\begin{array}{l}\text { Escherichia coli } \\
\text { ATCC } 35150\end{array}$ & 8 & 8 & 4 & 16 & 8 & 16 & $>128$ & 32 & 1 & NT & 8 & NT & NT \\
\hline $\begin{array}{l}\text { Escherichia coli } \\
\text { ATCC } 1411\end{array}$ & 32 & 16 & 16 & 16 & 8 & 32 & $>128$ & 64 & 0.5 & NT & 32 & NT & NT \\
\hline $\begin{array}{l}\text { Enterobacter } \\
\text { cloacae subsp. } \\
\text { cloacae ATCC } \\
\text { BAA-1143 }\end{array}$ & 16 & 8 & 8 & 8 & 8 & 16 & $>128$ & 64 & 1 & NT & 16 & NT & NT \\
\hline $\begin{array}{l}\text { Klebsiella } \\
\text { pneumoniae } \\
\text { BAA-1706 }\end{array}$ & 8 & 8 & 8 & 8 & 4 & 8 & $>128$ & 64 & 8 & NT & 8 & NT & NT \\
\hline
\end{tabular}




\begin{tabular}{|c|c|c|c|c|c|c|c|c|c|c|c|c|c|}
\hline $\begin{array}{l}\text { Klebsiella } \\
\text { pneumoniae } \\
\text { BAA-1144 }\end{array}$ & 16 & 16 & 32 & 16 & 8 & 32 & $>128$ & 64 & 32 & NT & 16 & NT & NT \\
\hline $\begin{array}{l}\text { Salmonella } \\
\text { enterica NR- } \\
170\end{array}$ & 16 & 8 & 8 & 8 & 16 & 16 & $>128$ & 64 & 1 & NT & 16 & NT & NT \\
\hline $\begin{array}{l}\text { Salmonella } \\
\text { enteritidis } \\
\text { ATCC } 13076\end{array}$ & 32 & 16 & 16 & 16 & 8 & 32 & $>128$ & 64 & 1 & NT & 32 & NT & NT \\
\hline $\begin{array}{l}\begin{array}{l}\text { Salmonella } \\
\text { enteritidis } \\
\text { ATCC } 14028\end{array} \\
\end{array}$ & 16 & 16 & 32 & 32 & 16 & 64 & $>128$ & 32 & 1 & NT & 16 & NT & NT \\
\hline $\begin{array}{l}\text { Salmonella } \\
\text { typhimurium } \\
\text { ATCC } 700720\end{array}$ & 16 & 16 & 16 & 8 & 8 & 64 & $>128$ & 64 & 1 & NT & 16 & NT & NT \\
\hline $\begin{array}{l}\text { Shigella } \\
\text { flexeneri АTCC } \\
9199\end{array}$ & 16 & 8 & 8 & 8 & 16 & 16 & $>128$ & 32 & 1 & NT & 16 & NT & NT \\
\hline $\begin{array}{l}\text { Pseudomonas } \\
\text { aeruginosa } \\
\text { ATCC } 9027\end{array}$ & 32 & 32 & 16 & 32 & 32 & 64 & $>128$ & 64 & 0.5 & NT & 32 & NT & NT \\
\hline $\begin{array}{l}\text { Pseudomonas } \\
\text { aeruginosa } \\
\text { ATCC } 25619\end{array}$ & 32 & 64 & 64 & 64 & 32 & 32 & $>128$ & 64 & 0.5 & NT & 32 & NT & NT \\
\hline $\begin{array}{l}\text { Pseudomonas } \\
\text { aeruginosa } \\
\text { ATCC } 15442\end{array}$ & 16 & 32 & 32 & 32 & 64 & 64 & $>128$ & 64 & 2 & NT & 16 & NT & NT \\
\hline $\begin{array}{l}\text { Escherichia coli } \\
\text { ATCC BAA- } \\
2452\end{array}$ & 32 & 16 & 16 & 16 & 8 & 64 & 32 & 64 & 64 & NT & NT & 32 & 16 \\
\hline $\begin{array}{l}\text { Escherichia coli } \\
\text { ATCC BAA- } \\
2469\end{array}$ & 32 & 16 & 8 & 16 & 8 & 64 & 32 & 64 & 64 & NT & NT & 32 & 16 \\
\hline $\begin{array}{l}\text { Klebsiella } \\
\text { pneumoniae } \\
\text { ATTC BAA- } \\
\text { 1705 } \\
\end{array}$ & 32 & 16 & 16 & 32 & 16 & 64 & 64 & 32 & 32 & NT & NT & 32 & 16 \\
\hline $\begin{array}{l}\text { Klebsiella } \\
\text { pneumoniae } \\
\text { ATTC BAA- } \\
2146\end{array}$ & 64 & 32 & 16 & 32 & 32 & $>64$ & 64 & 64 & 64 & NT & NT & 64 & 32 \\
\hline $\begin{array}{l}\text { Acinetobacter } \\
\text { baumannii } \\
\text { ATCC BAA } \\
1605\end{array}$ & 32 & 16 & 8 & 8 & 16 & 64 & 16 & 64 & 64 & NT & NT & 32 & 16 \\
\hline $\begin{array}{l}\text { Pseudomonas } \\
\text { aeruginosa } \\
\text { ATCC } 1744\end{array}$ & 64 & 64 & 64 & 32 & 32 & 64 & 32 & 32 & 32 & NT & NT & 64 & 64 \\
\hline
\end{tabular}

Lin: Linezolid

Van: Vancomycin

Gen: gentamicin

Imp: Imipenem

Mer: Meropenem

NT: Not-tested 


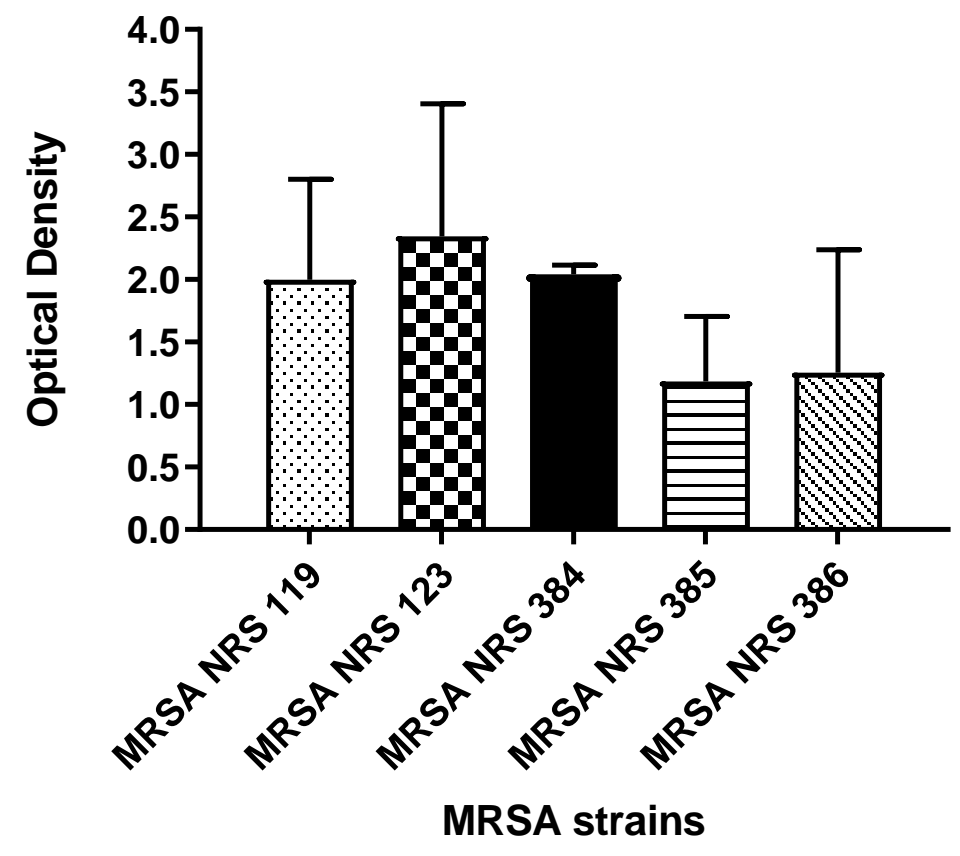

Figure (2S). Biofilm detection of different clinically-relevant Methicillin-resistant Staphylococcus aureus strains.

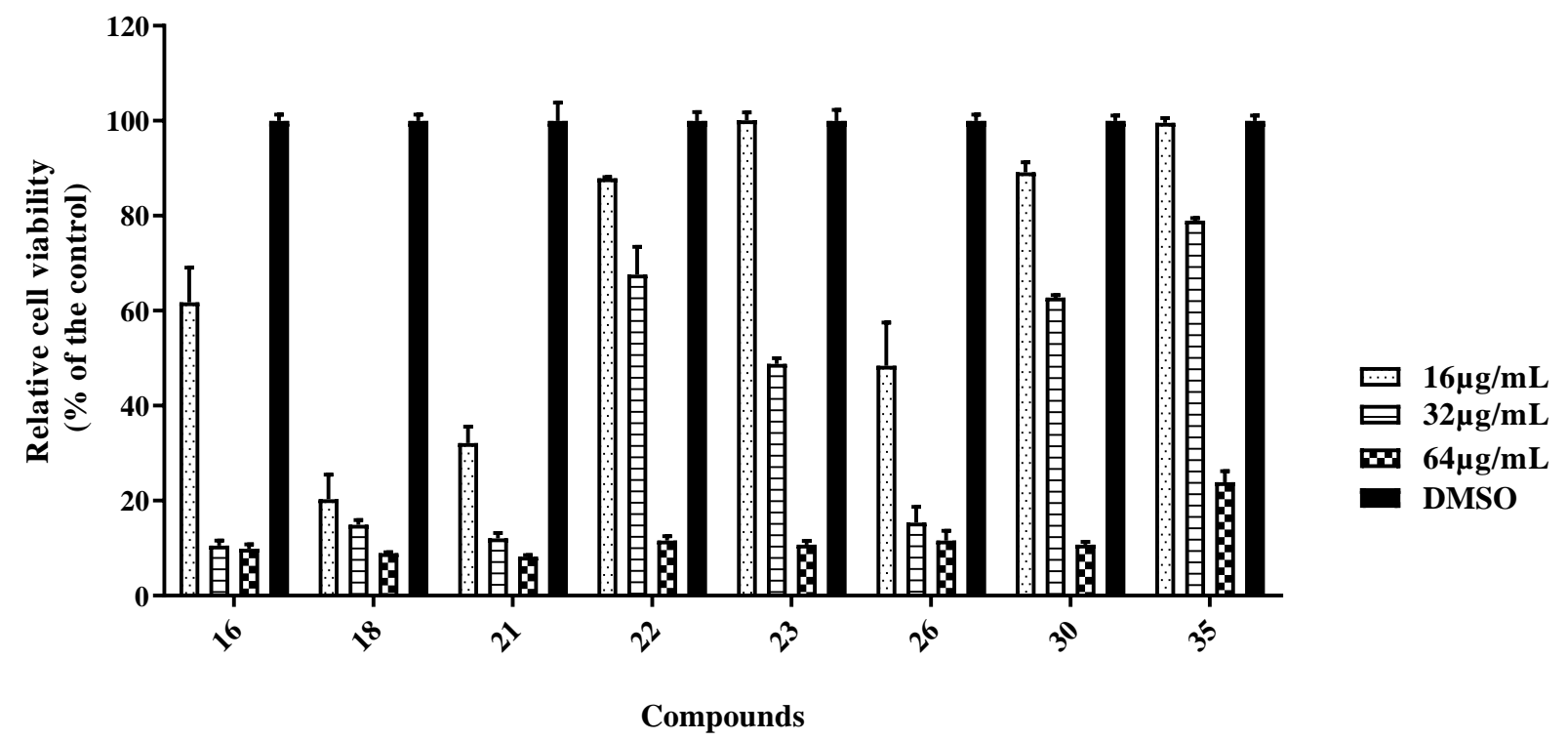

Figure 3S. Toxicity analysis of tested compounds against fibroblast-like monkey kidney cell line (VERO cell). Percent viable mammalian cells (measured as average absorbance ratio (test agent relative to DMSO) for cytotoxicity analysis of tested compounds (tested in 
triplicates) at 16, 32 and $64 \mu \mathrm{g} / \mathrm{mL}$ against VERO cells using the MTS 3-(4,5-dimethylthiazol2-yl)-5-(3-carboxymethoxyphenyl)-2-(4-sulfophenyl)-2H-tetrazolium) assay. Dimethyl sulfoxide (DMSO) was used as a negative control to determine a baseline measurement for the cytotoxic impact of each compound. The absorbance values represent an average of a minimum of three samples analyzed for each compound. Error bars represent standard deviation values for the absorbance values.

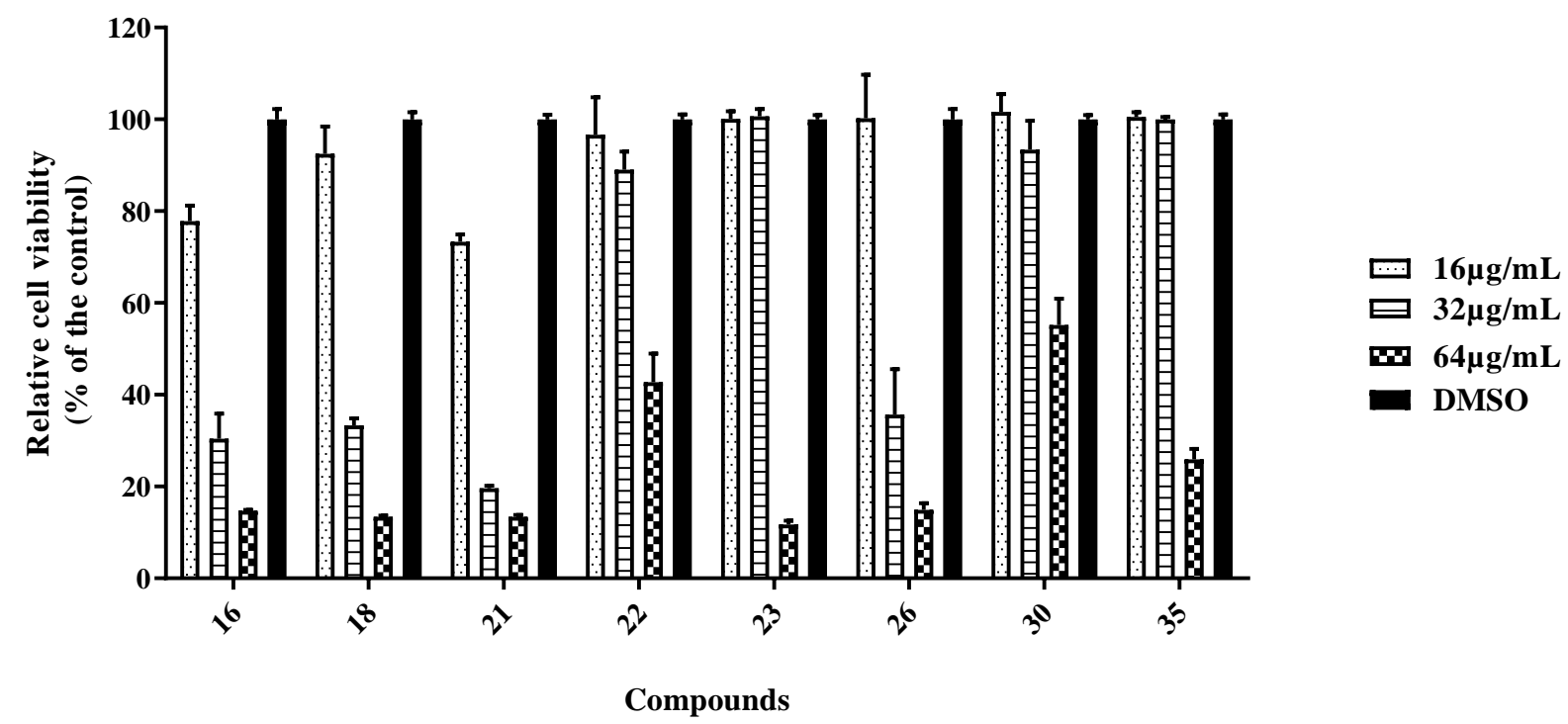

Figure 4S. Toxicity analysis of tested compounds against human colorectal cells (Caco-2). Percent viable mammalian cells (measured as average absorbance ratio (test agent relative to DMSO) for cytotoxicity analysis of tested compounds (tested in triplicate) at 16, 32, and $64 \mu \mathrm{g} / \mathrm{mL}$ against Caco-2 cells using the MTS 3-(4,5-dimethylthiazol-2-yl)-5-(3carboxymethoxyphenyl)-2-(4-sulfophenyl)-2H-tetrazolium) assay. Dimethyl sulfoxide (DMSO) was used as a negative control to determine a baseline measurement for the cytotoxic impact of each compound. The absorbance values represent an average of a minimum of three samples analyzed for each compound. Error bars represent standard deviation values for the absorbance values. 


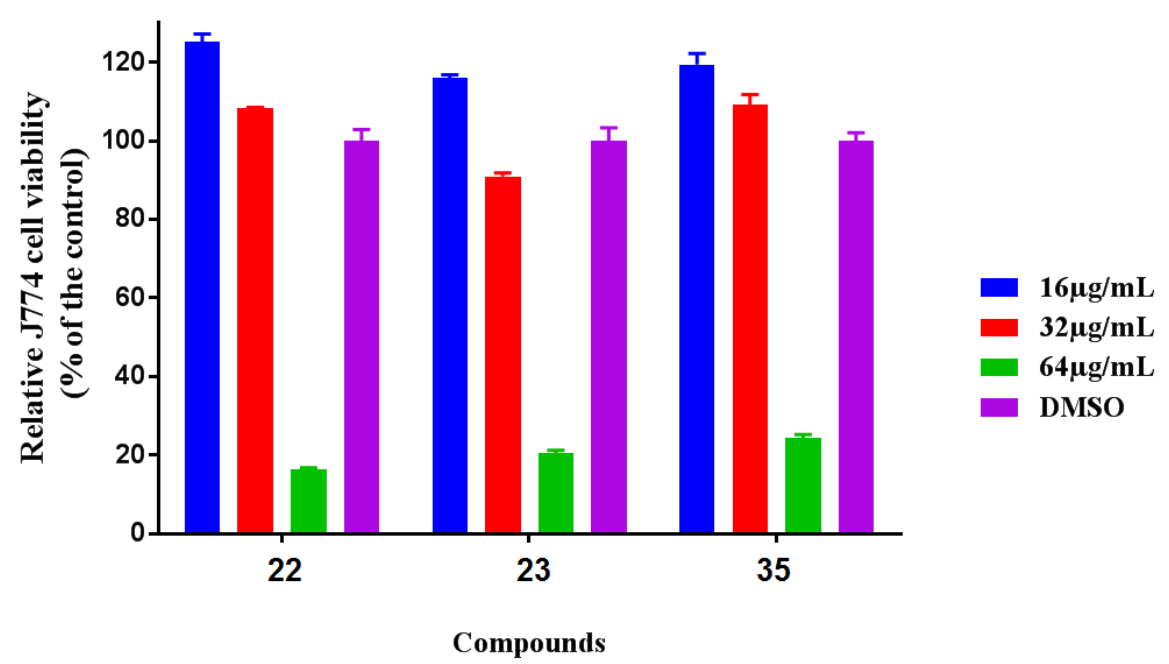

Figure 5S. Testing the tolerability of phenylpyrazoles against murine macrophage (J774) cells using the MTS 3-(4,5-dimethylthiazol-2-yl)-5-(3-carboxymethoxyphenyl)-2-(4-sulfophenyl)-2Htetrazolium) assay. Results are presented as percent viable mammalian cells (measured as average absorbance ratio relative to DMSO). The absorbance values represent an average of a minimum of three samples analyzed for each compound. Error bars represent standard deviation values for the absorbance values. 


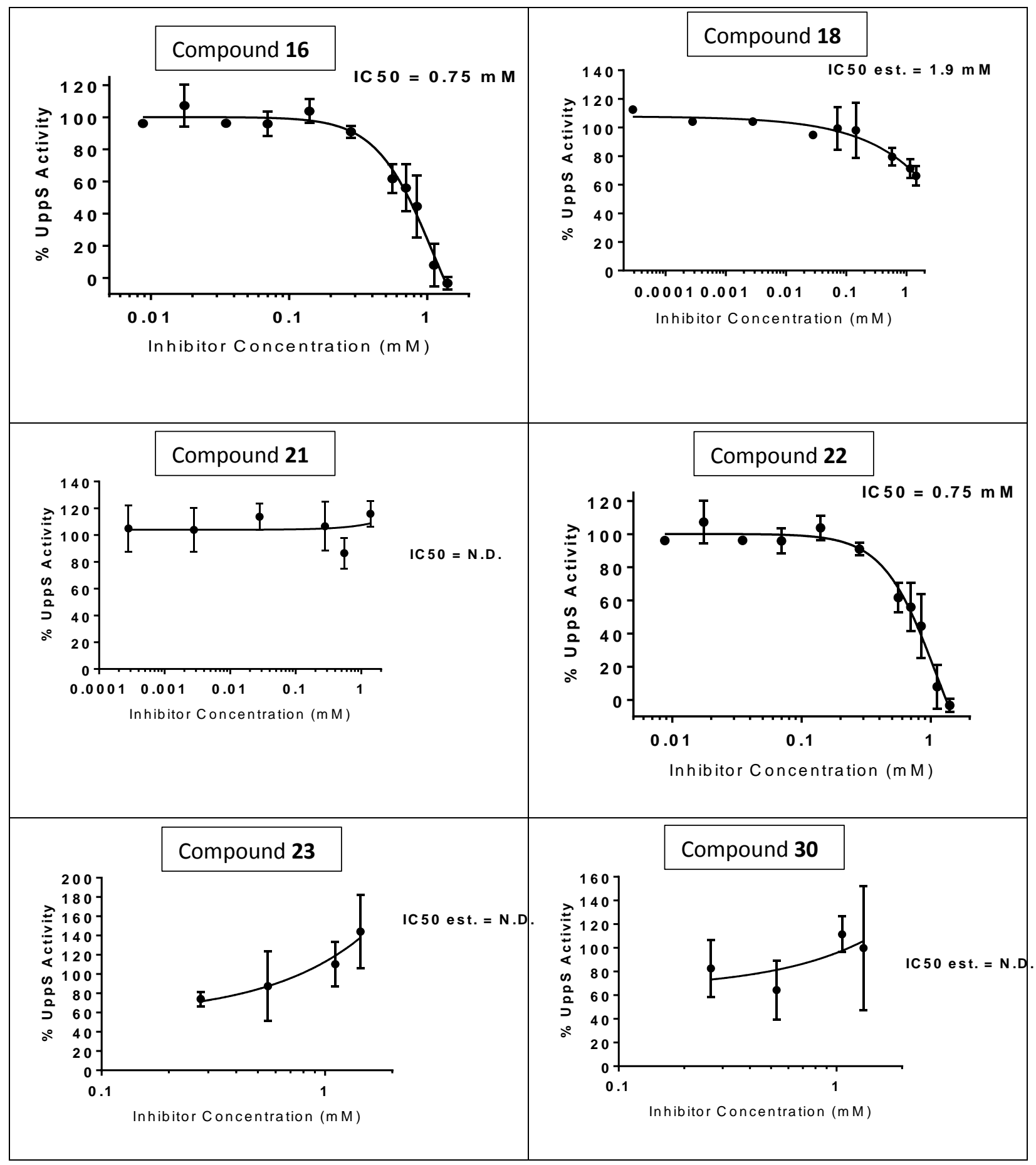




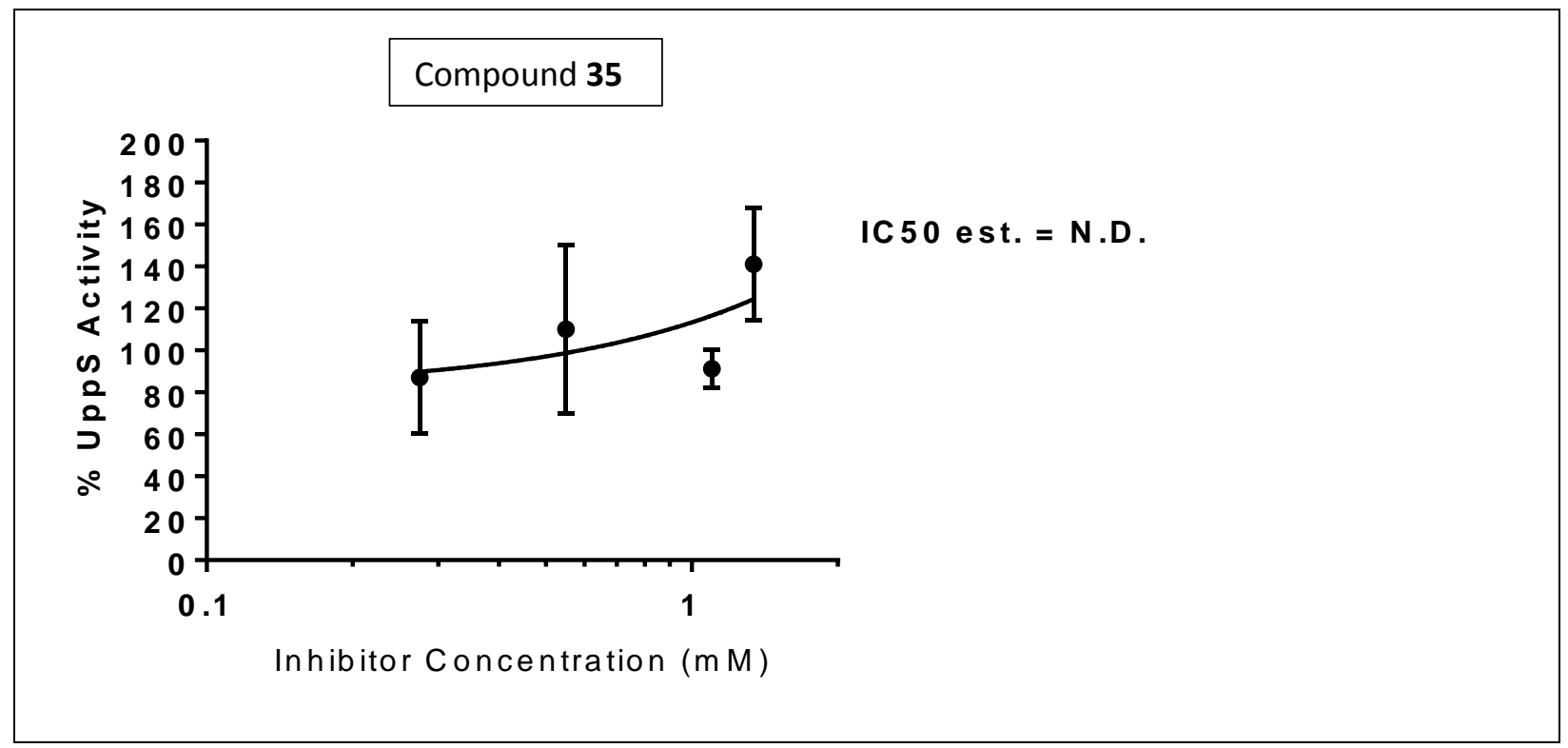

Figure 6S. Inhibitory activity against UppS 


\section{Methods}

Determination of the minimum inhibitory concentration (MIC) and minimum bactericidal concentration (MBC) against different Gram-positive and Gram-negative bacterial strains. The minimum inhibitory concentration (MIC) of tested compounds and control antibiotics (linezolid and vancomycin) was determined using the broth microdilution method against all clinical isolates using the broth microdilution method according to the guidelines outlined by the Clinical and Laboratory Standards Institute (CLSI) ${ }^{1}$. Bacterial strains were grown aerobically overnight on tryptone soy agar plates at $37^{\circ} \mathrm{C}$ (with the exception of Clostridium difficile which was cultured in brain heart infusion supplemented agar; supplemented with hemin, vitamin K and L-cysteine at $37^{\circ} \mathrm{C}$ for 48 hours). Afterwards, a bacterial solution equivalent to $0.5 \mathrm{McFarland}$ standard was prepared and diluted in cation-adjusted Mueller-Hinton broth (CAMHB) to achieve a bacterial concentration of about $5 \times 10^{5} \mathrm{CFU} / \mathrm{mL}$ and seeded in 96-well plates. Enterococcus faecium, Enterococcus faecalis, Streptococcus pneumonia and Listeria monocytogenes were diluted in tryptone soy broth. Clostridium difficile was diluted in brain heart infusion supplemented broth (supplemented with yeast extract, hemin and vitamin K); to achieve a bacterial concentration of about $5 \times 10^{5} \mathrm{CFU} / \mathrm{mL}$ and seeded in 96-well plates. Compounds and control drugs were added in the first row of the 96-well plates and serially diluted (to achieve a concentration gradient ranging from 128 to $1 \mu \mathrm{g} / \mathrm{mL}$ ). Plates were then incubated aerobically at $37^{\circ} \mathrm{C}$ for $18-20$ hours (except for C. difficile which was incubated anaerobically at $37^{\circ} \mathrm{C}$ for 48 hours and $S$. pneumoniae which was incubated at $37^{\circ} \mathrm{C}+5 \% \mathrm{CO}_{2}$ for $18-20$ hours). MICs reported are the minimum concentration of the compounds and control drugs that could completely inhibit the visual growth of bacteria. The minimum bactericidal concentration $(\mathrm{MBC})$ of these compounds was tested (except against $C$. difficile) by plating $5 \mu \mathrm{L}$ from wells with no growth onto Tryptic soy agar plates. Plates were 
incubated at $37^{\circ} \mathrm{C}$ for at least 18 hours before recording the $\mathrm{MBC}$. The $\mathrm{MBC}$ was categorized as the lowest concentration that reduced bacterial growth by $99.9 \%$.

Time-kill assay against MRSA. A time kill assay for the phenylpyrazoles against MRSA400 was performed as described previously ${ }^{2,3}$. MRSA USA400 cells in logarithmic growth phase $\left(\mathrm{OD}_{600} \sim 1.00\right)$ were diluted to $2.97 \times 10^{6}$ colony-forming units $(\mathrm{CFU} / \mathrm{mL})$ and exposed to concentrations equivalent to $5 \times$ MIC (in triplicate) of tested compounds and vancomycin in Tryptic soy broth. Aliquots $(100 \mu \mathrm{L})$ were collected from each treatment after $0,2,4,6,8,10,12$ and 24 hours of incubation at $37^{\circ} \mathrm{C}$ and subsequently serially diluted in PBS. Bacteria were then transferred to Tryptic soy agar plates and incubated at $37^{\circ} \mathrm{C}$ for $18-20$ hours before viable CFU/mL was determined.

In vitro cytotoxicity analysis against VERO cells and caco-2 cells. Tested compounds were assayed (at concentrations of 16, 32, and $64 \mu \mathrm{g} / \mathrm{mL}$ ) against a fibroblast-like monkey kidney cell line (VERO cell) and against a human colorectal (Caco-2) cell as described previously ${ }^{1,4}$ to determine their in vitro potential toxic effect. Briefly, Vero cells were cultured in Minimum Essential Medium (MEM) supplemented with 10\% fetal bovine serum (FBS), 1 mM sodium pyruvate, and penicillin-streptomycin at $37{ }^{\circ} \mathrm{C}$ with $\mathrm{CO}_{2}(5 \%)$. Caco-2 cells were cultured in Dulbecco's Modified Eagle Medium (DMEM) supplemented with 10\% fetal bovine serum (FBS), non-essential amino acids (1X), penicillin-streptomycin at $37{ }^{\circ} \mathrm{C}$ with $\mathrm{CO}_{2}(5 \%)$. Control cells received DMSO alone at a concentration equal to that in drug-treated cell samples. The cells were incubated with the compounds (in triplicate) in a 96 -well plate at $37^{\circ} \mathrm{C}$ with $\mathrm{CO}_{2}(5 \%)$ for two hours. The assay reagent MTS 3-(4,5-dimethylthiazol-2-yl)-5-(3-carboxymethoxyphenyl)-2-(4sulfophenyl)-2H-tetrazolium) (Promega, Madison, WI, USA) was subsequently added and the plate was incubated for four hours. Absorbance readings (at $\mathrm{OD}_{490}$ ) were recorded using a kinetic 
microplate reader (Molecular Devices, Sunnyvale, CA, USA). The quantity of viable cells after treatment with each compound was expressed as a percentage of the viability of DMSO-treated control cells (average of triplicate wells \pm standard deviation). The toxicity data was analyzed via a two-way ANOVA, with post hoc Dunnet's multiple comparisons test $(P<0.05)$, utilizing GraphPad Prism 6.0 (GraphPad Software, La Jolla, CA).

\section{Pharmacokinetic assays}

Human Microsomal Stability Analysis. The tested compounds were incubated in duplicate with human liver microsomes (pooled from human donors) at $37^{\circ} \mathrm{C}$. The reaction contained microsomal protein in $100 \mathrm{mM}$ potassium phosphate, $2 \mathrm{mM} \mathrm{NADPH}, 3 \mathrm{mM} \mathrm{MgCl} 2, \mathrm{pH}$ 7.4. A control was run for each test agent omitting NADPH to detect NADPH-free degradation. At 0, 15, 30,45 , and 60 minutes, an aliquot was removed from each experimental and control reaction and mixed with an equal volume of ice-cold Stop Solution (methanol containing haloperidol, diclofenac, or other internal standard). Stopped reactions are incubated at least ten minutes at -20 ${ }^{\circ} \mathrm{C}$, and an additional volume of water was added. The samples were centrifuged to remove precipitated protein, and the supernatants were analyzed by LC/MS/MS to quantitate the remaining parent. Data are converted to \% remaining by dividing by the time zero concentration value. Data are fit to a first-order decay model to determine half-life. Intrinsic clearance is calculated from the half-life and the protein concentrations: $C L_{i n t}=\ln (2) /\left(T_{1 / 2}[\right.$ microsomal protein] $)$.

Caco-2 Permeability Assay. Caco-2 cells (Cyprotex Inc.) grown in tissue culture flasks were trypsinized, suspended in medium, and the suspensions were applied to wells of a Millipore 96 well Caco-2 plate. The cells were allowed to grow and differentiate for three weeks, feeding at two-day intervals. For Apical to Basolateral $(\mathrm{A} \rightarrow \mathrm{B})$ permeability, the tested compound was added to the apical (A) side and the amount of permeation was determined on the basolateral (B) side; 
for Basolateral to Apical $(\mathrm{B} \rightarrow \mathrm{A})$ permeability, tested compound was added to the $\mathrm{B}$ side and the amount of permeation was determined on the A side. The A-side buffer contained $100 \mu \mathrm{M}$ Lucifer yellow dye, in Transport Buffer (1.98 g/L glucose in 10 mM HEPES, 1.0× Hank's Balanced Salt Solution) $\mathrm{pH}$ 6.5, and the B-side buffer contained Transport Buffer at $\mathrm{pH}$ 7.4. Caco-2 cells were incubated with these buffers for $2 \mathrm{~h}$, and the receiver side buffer was removed for analysis by LC/MS/MS. To verify the Caco-2 cell monolayers were properly formed, aliquots of the cell buffers were analyzed by fluorescence to determine the transport of the impermeable dye Lucifer Yellow. Any deviations from control values are reported. Data are expressed as permeability $($ Papp $)=(d Q / d t) / C_{0} A$ where $\mathrm{dQ} / \mathrm{dt}$ is the rate of permeation, $\mathrm{C}_{0}$ is the initial concentration of test agent, and $\mathrm{A}$ is the area of the monolayer. In bidirectional permeability studies, the efflux ratio $\left(\mathrm{R}_{\mathrm{E}}\right)$ is also calculated: $\mathrm{R}_{\mathrm{E}}=(\operatorname{Papp}(\mathrm{B} \rightarrow \mathrm{A})) /(\operatorname{Papp}(\mathrm{A} \rightarrow \mathrm{B}))$. An $\mathrm{R}_{\mathrm{E}}>2$ indicates a potential substrate for P-glycoprotein or other active efflux transporters.

In vivo Pharmacokinetics. Pharmacokinetic studies were performed in male naïve Sprague-Dawley (SD) rats (three animals) following Al-Azhar University Animal Care and Use Committee guidelines. An IV bolus of a $5 \mathrm{mg} / \mathrm{Kg}$ was directly administered. Blood samples were collected over a 12-hour period post dose into Vacutainer tubes containing EDTA-K2. Plasma was isolated, and the concentration of tested compounds in plasma was determined with LC/MS/MS after protein precipitation with acetonitrile. Two-compartmental pharmacokinetic analysis was performed on plasma concentration data in order to calculate pharmacokinetic parameters as previously reported. ${ }^{1}$

\section{Biochemical assays}

Protein Purification. E. coli UppP in pET28a with a 6X His tag was expressed and purified using affinity chromatography. Briefly, transformed C41 (DE3) cells were grown 
exponentially in 2xYT media, induced with $1 \mathrm{mM}$ IPTG at $\mathrm{OD}_{600} 0.7$, and expressed overnight at $22^{\circ} \mathrm{C}$. Harvested cells were washed with STE buffer (10 mM Tris- $\mathrm{HCl}(\mathrm{pH} 8.0), 0.1 \mathrm{mM}$ EDTA, $0.1 \mathrm{M} \mathrm{NaCl}$ ), and resuspended in buffer A (25 mM Tris- $\mathrm{HCl}(\mathrm{pH} 7.2), 150 \mathrm{mM} \mathrm{NaCl}, 5 \mathrm{mM} 2-$ mercaptoethanol, $10 \%$ glycerol $(\mathrm{v} / \mathrm{v}))$. Cells were disrupted by sonication and centrifuged at 10,000 RPM for $30 \mathrm{~min}$. Membrane extracts were then suspended in buffer A and the detergent DDM was added to a final concentration of $1.5 \%$. This mixture was incubated overnight at $4{ }^{\circ} \mathrm{C}$ with end-over-end rotation. A second centrifugation yielded a soluble extract which was further used for purification. The soluble extract was incubated at $4^{\circ} \mathrm{C}$ for $3 \mathrm{~h}$ with $0.5 \mathrm{~mL}$ of Ni-NTA equilibrated with buffer B (25 mM Tris- $\mathrm{HCl}$ (pH 7.2), $300 \mathrm{mM} \mathrm{NaCl}, 5 \mathrm{mM}$ 2-mercaptoethanol, $20 \%$ glycerol (v/v)), supplemented with $20 \mathrm{mM}$ imidazole. The protein bound slurry was packed in a $2 \mathrm{~mL}$ Biorad column and washed with $150 \mathrm{~mL}$ buffer B containing $0.1 \%$ DDM. Protein was eluted using $300 \mathrm{mM}$ imidazole in buffer B at $\mathrm{pH} 7.2$, then stored in buffer B without DDM at $80^{\circ} \mathrm{C}$. The purity and integrity of recombinant proteins were checked by SDS-PAGE gel.

Enzymatic inhibition Assays. Putative inhibitors for UppP were serially diluted from 1 $\mathrm{mM}$ to $1 \mathrm{nM}$ in DMSO. Inhibitors were incubated with $20 \mathrm{nM}$ of UppP at room temperature for $15 \mathrm{~min}$ in assay buffer (50 mM HEPES, $150 \mathrm{mM} \mathrm{NaCl}, 10 \mathrm{mM} \mathrm{MgCl}_{2}$, and $0.02 \% \mathrm{DDM}$ ) before adding $35 \mu \mathrm{M}$ FPP to start the reaction. Reaction mixtures were incubated at $37^{\circ} \mathrm{C}$ for $20 \mathrm{~min}$, then quenched by addition of malachite-green reagent ${ }^{5}$. Phosphate release was measured at $620 \mathrm{~nm}$ and values obtained were used to yield a dose-response curve. 


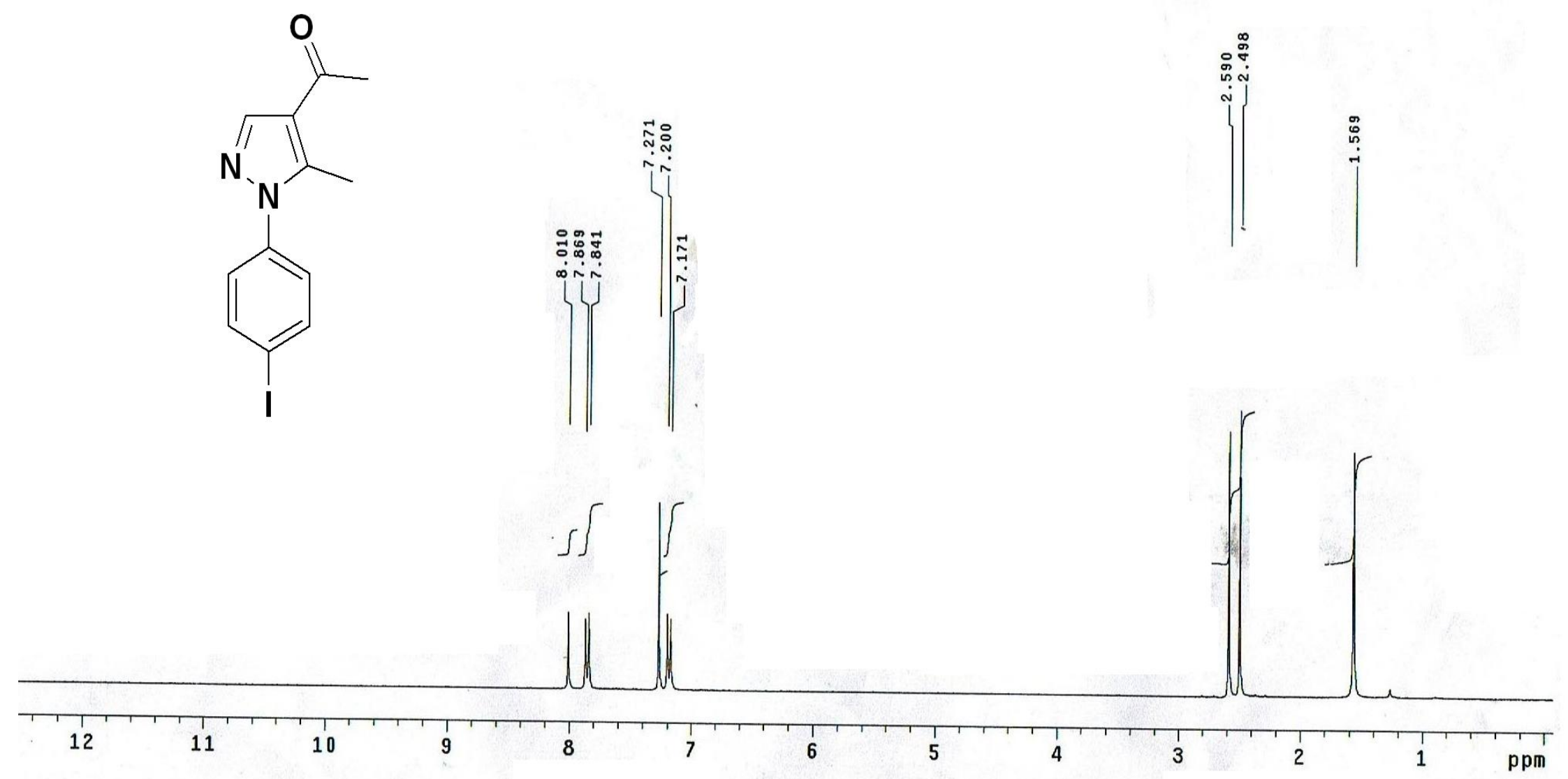

${ }^{1} \mathrm{H}$ NMR of compound $\mathbf{3}$ 


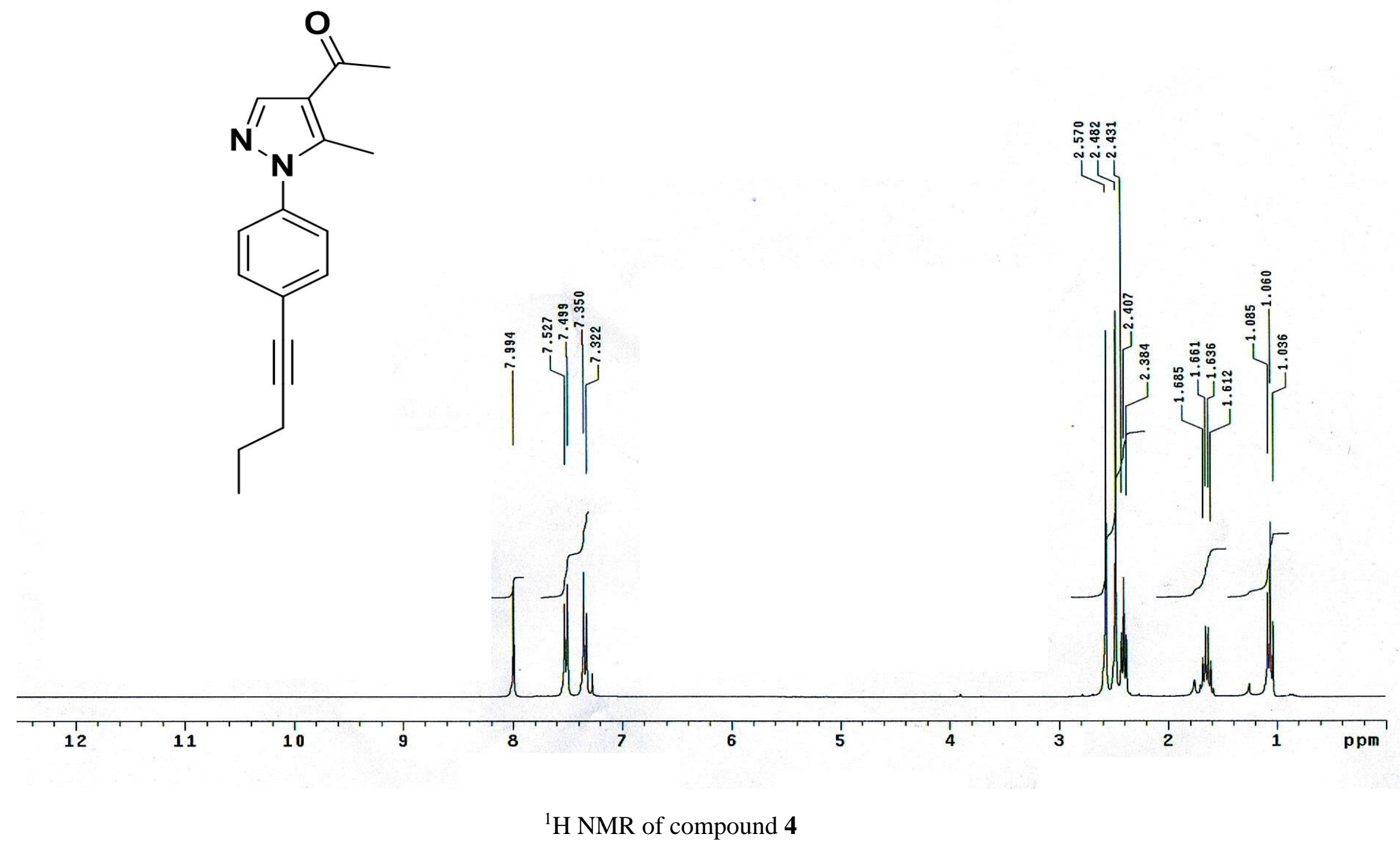




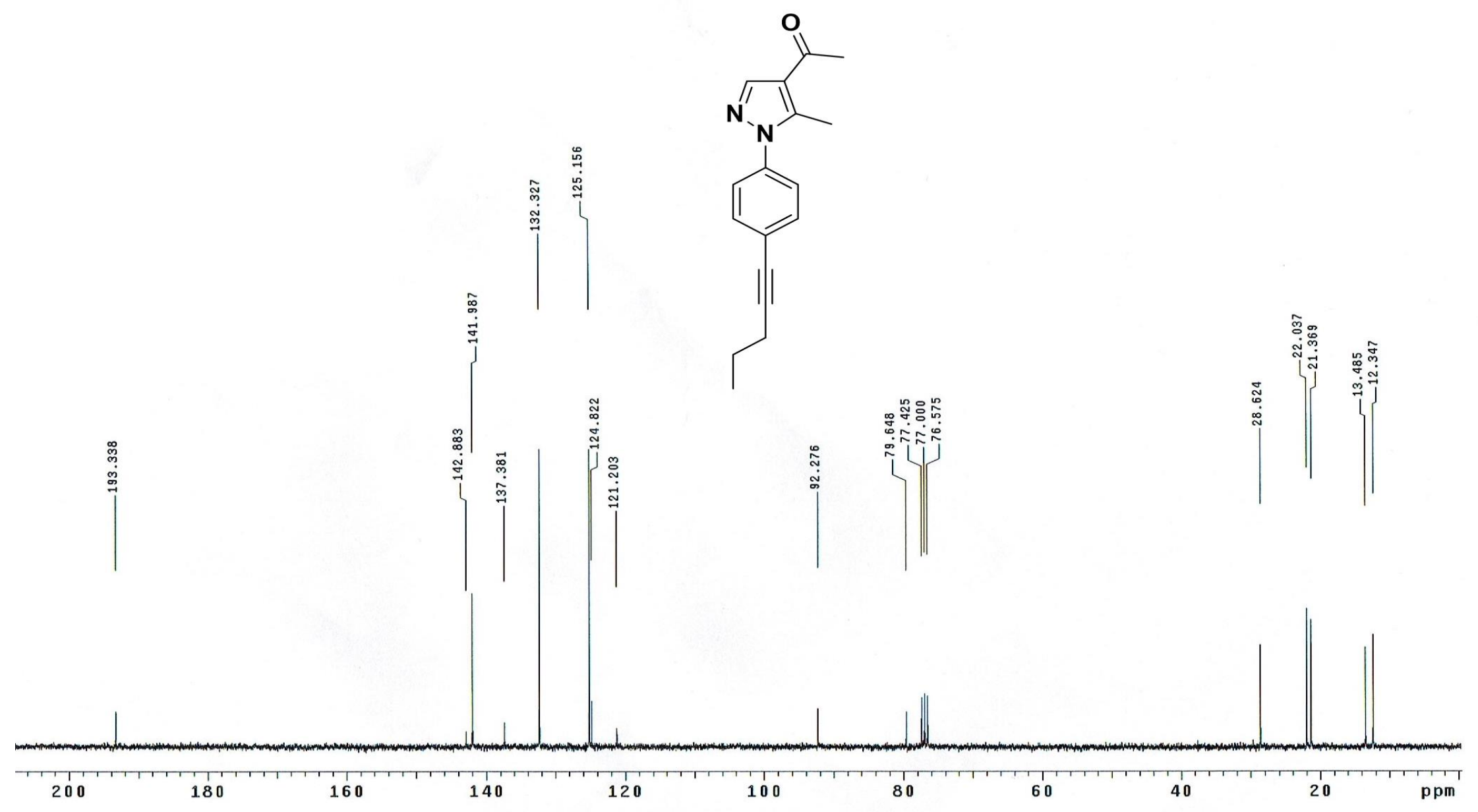

${ }^{13} \mathrm{C}$ NMR of compound 4 


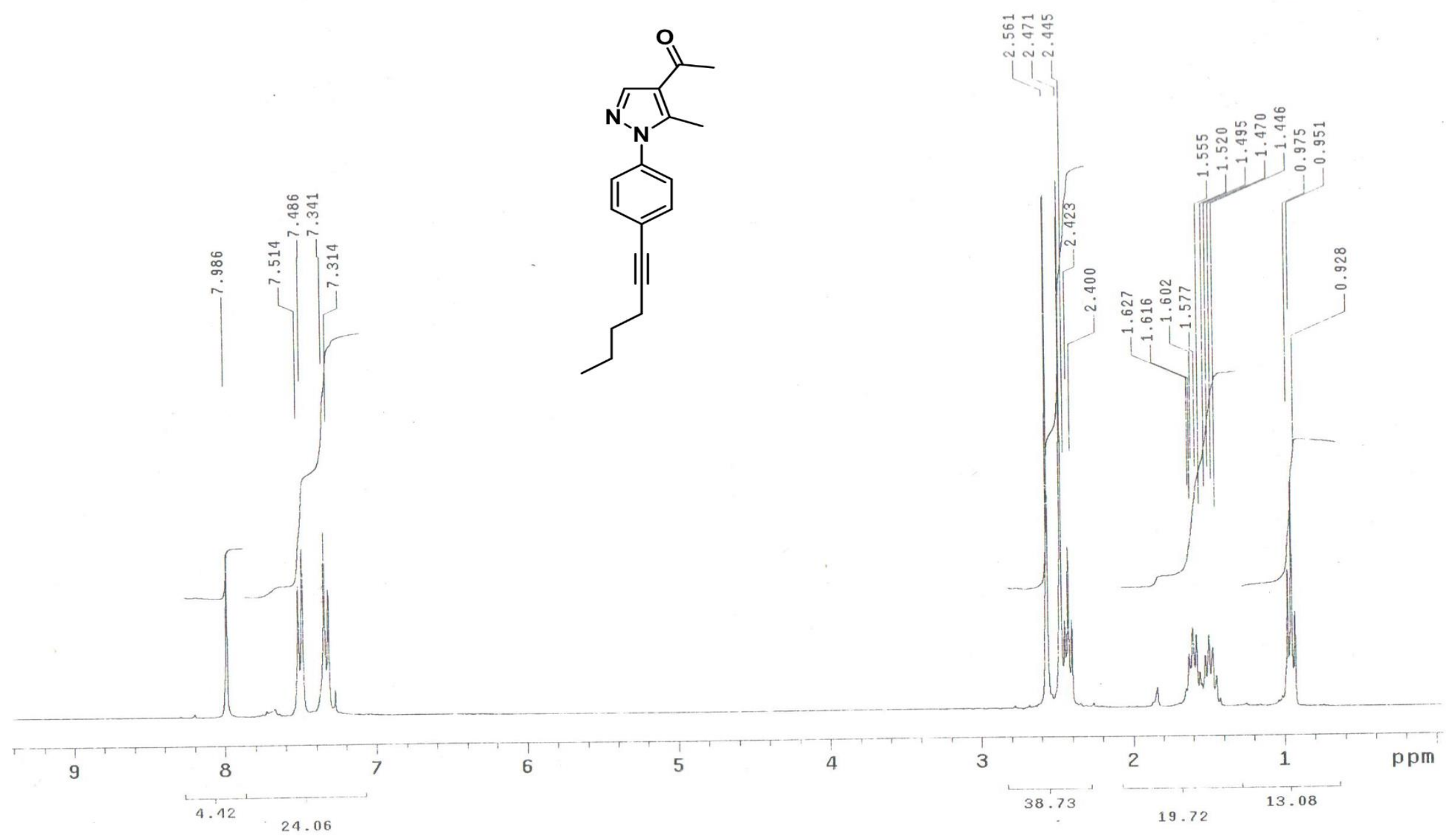

${ }^{1} \mathrm{H}$ NMR of compound 5 


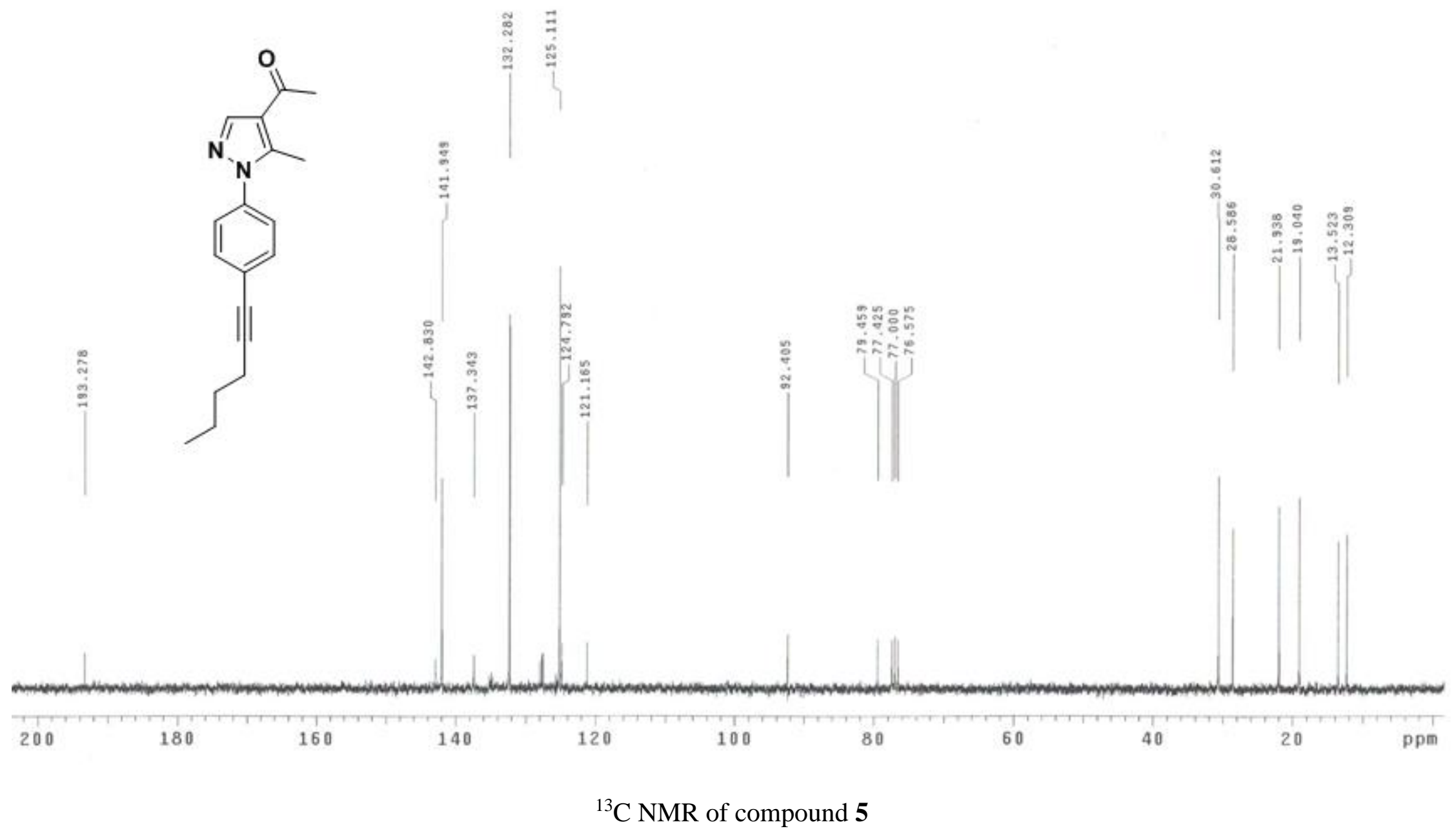




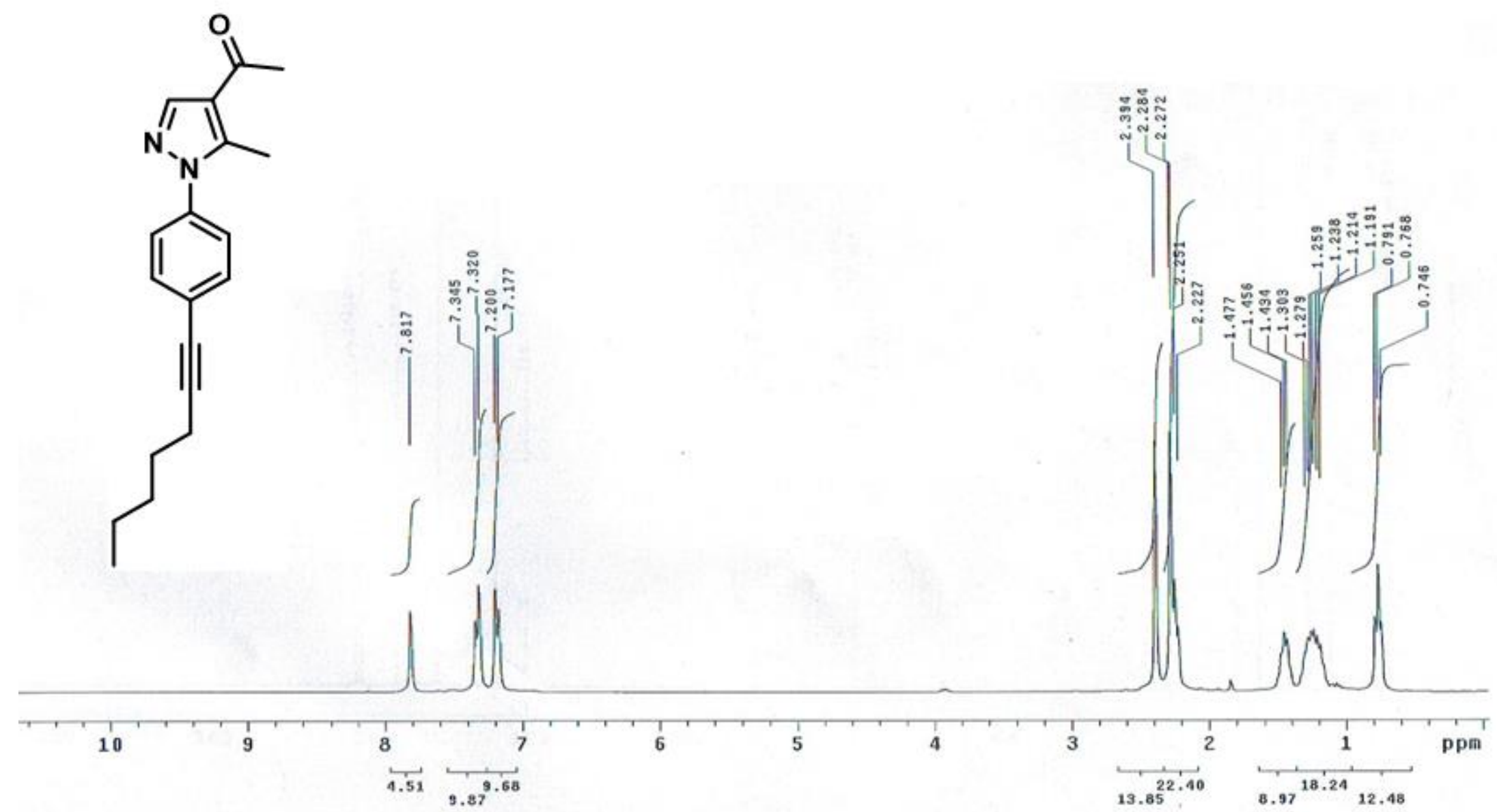

${ }^{1} \mathrm{H}$ NMR of compound $\mathbf{6}$ 


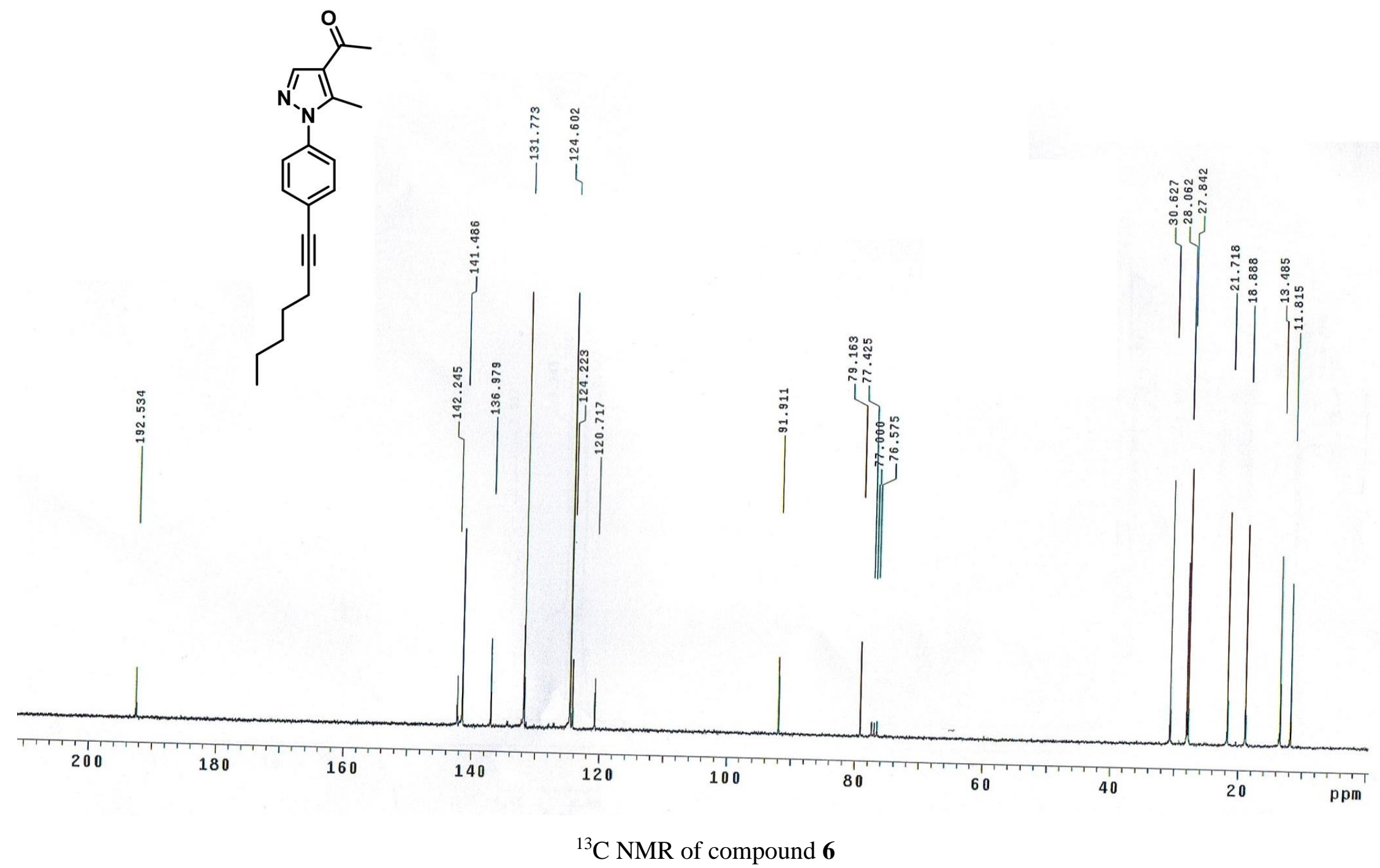




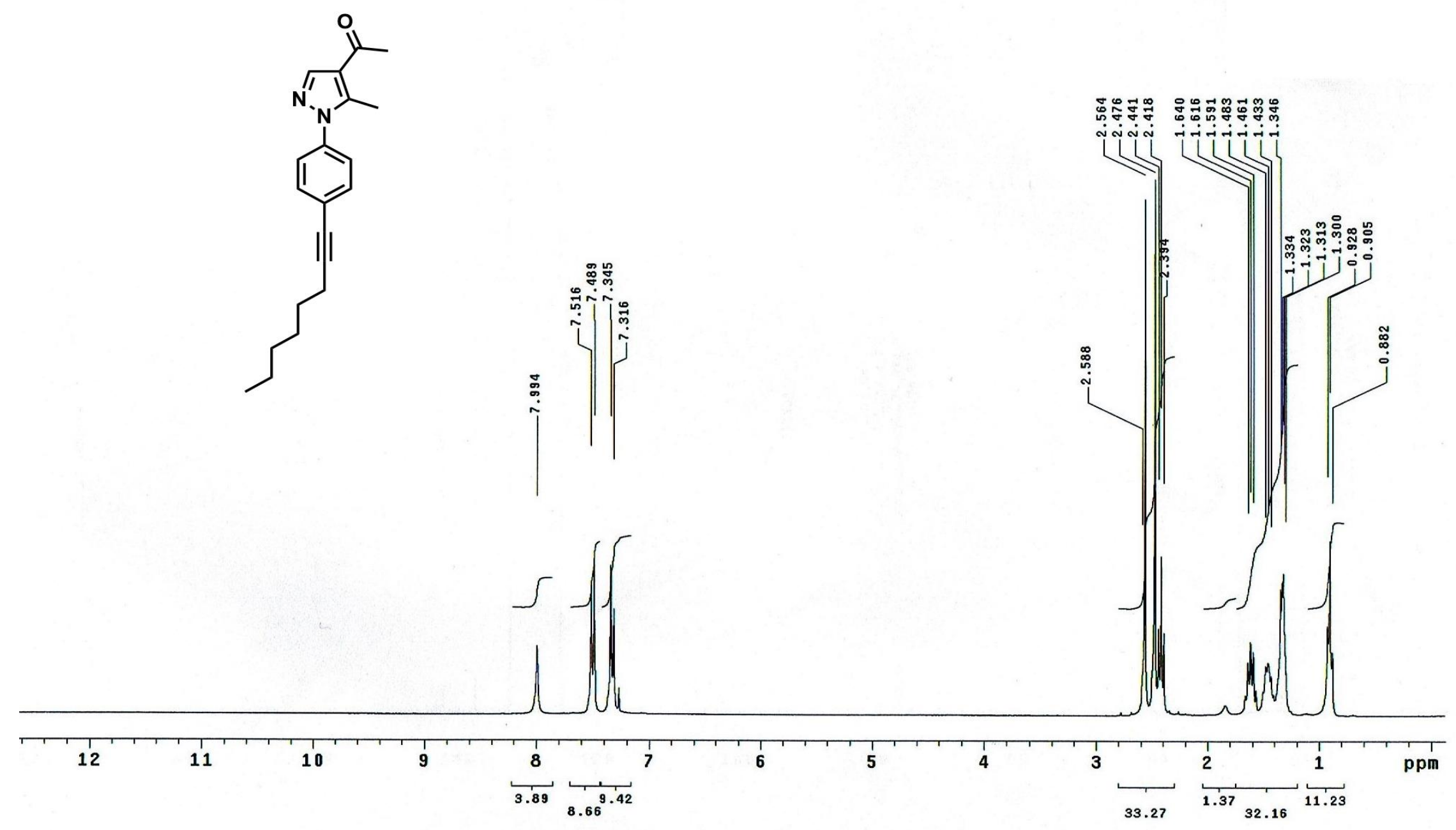

${ }^{1} \mathrm{H}$ NMR of compound 7 


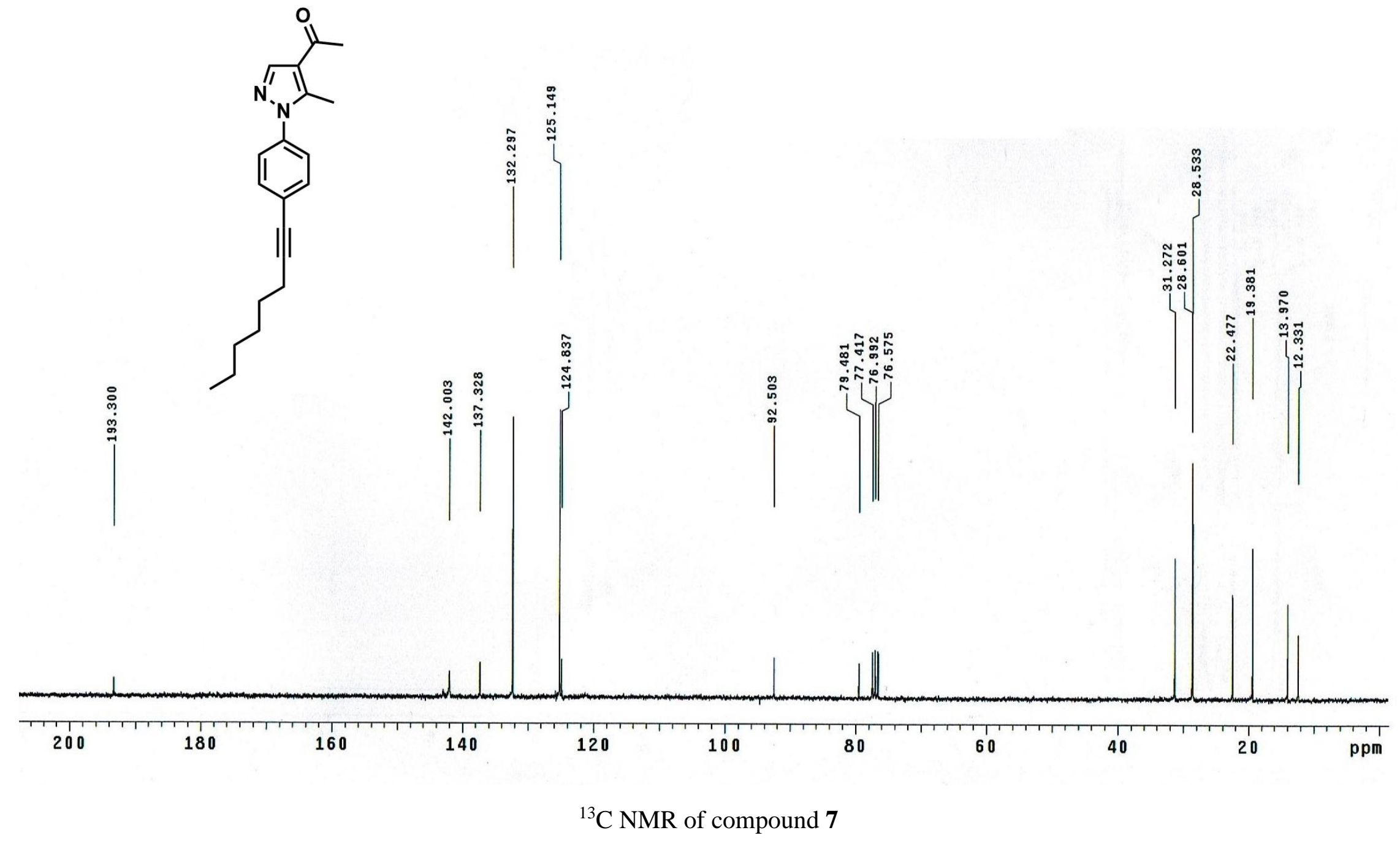




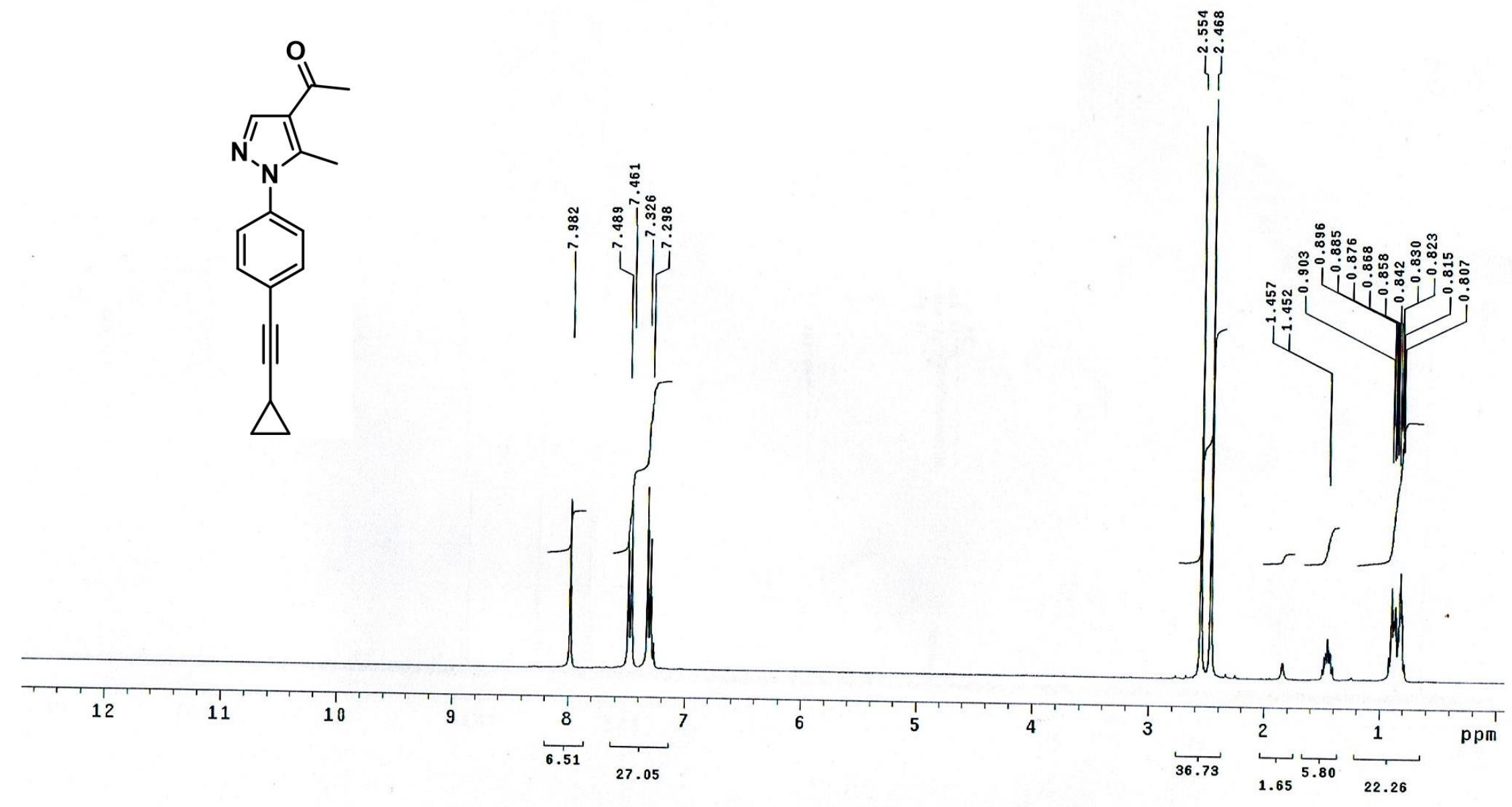

${ }^{1} \mathrm{H}$ NMR of compound $\mathbf{8}$ 


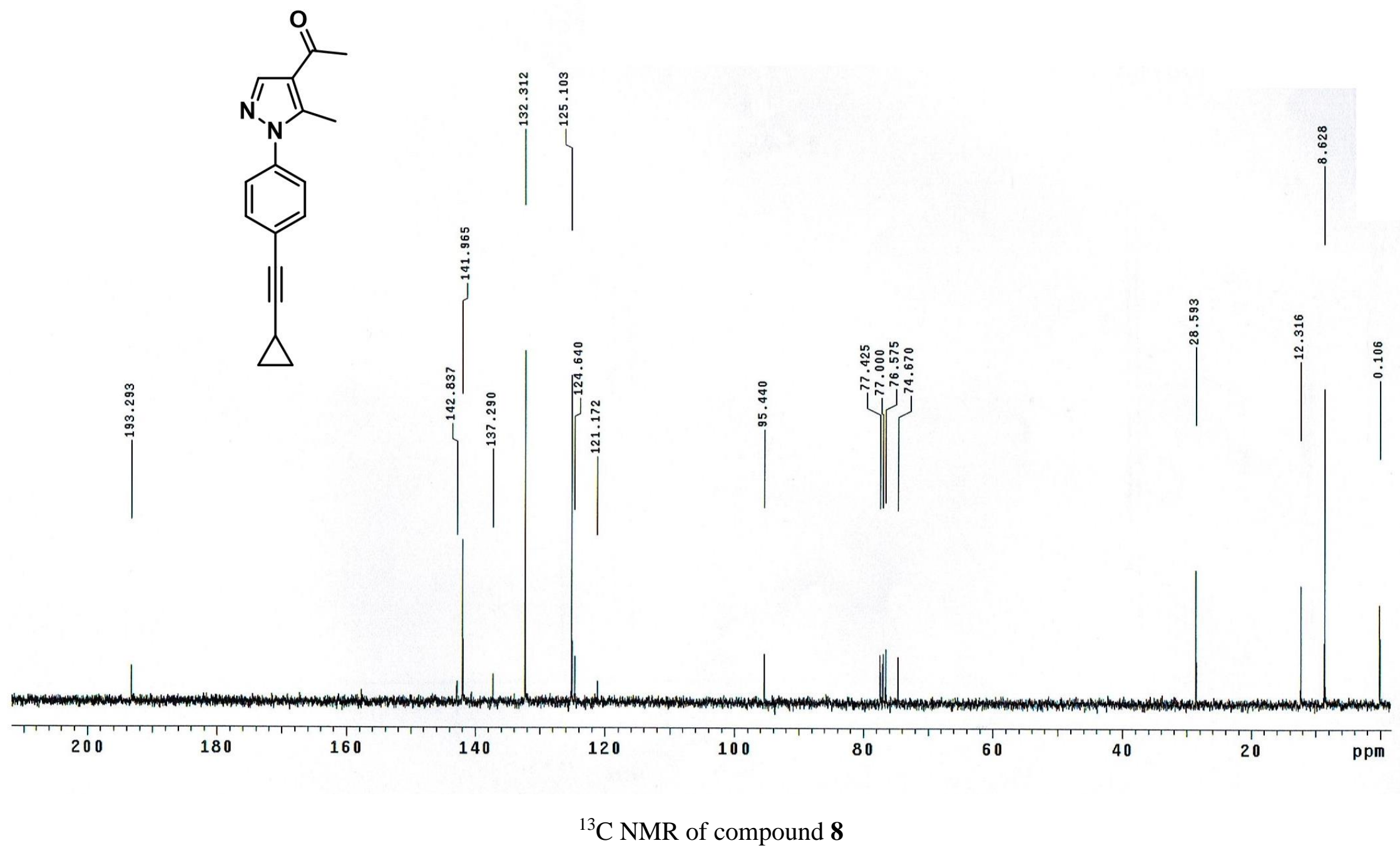




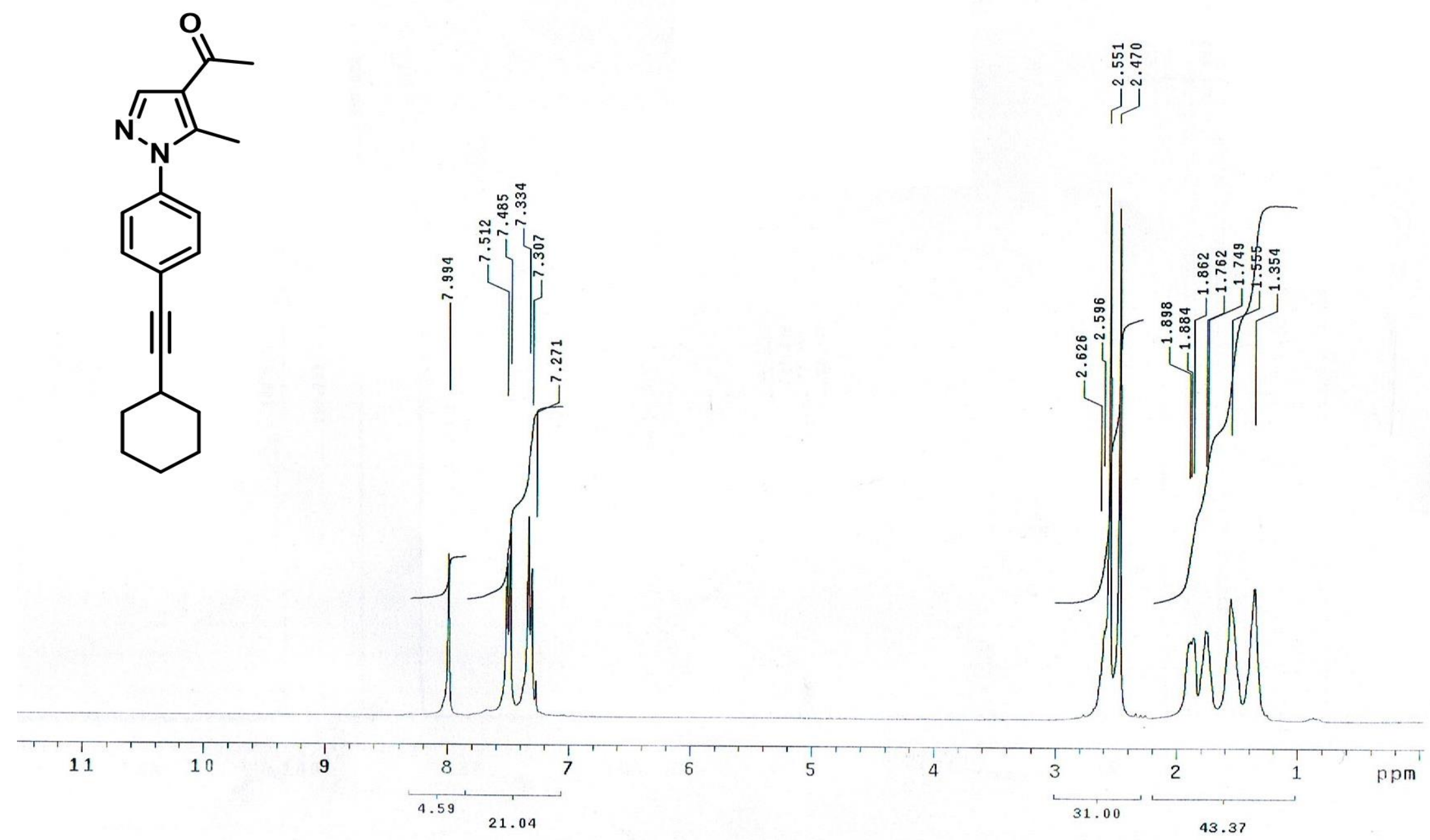

${ }^{1} \mathrm{H}$ NMR of compound 9 


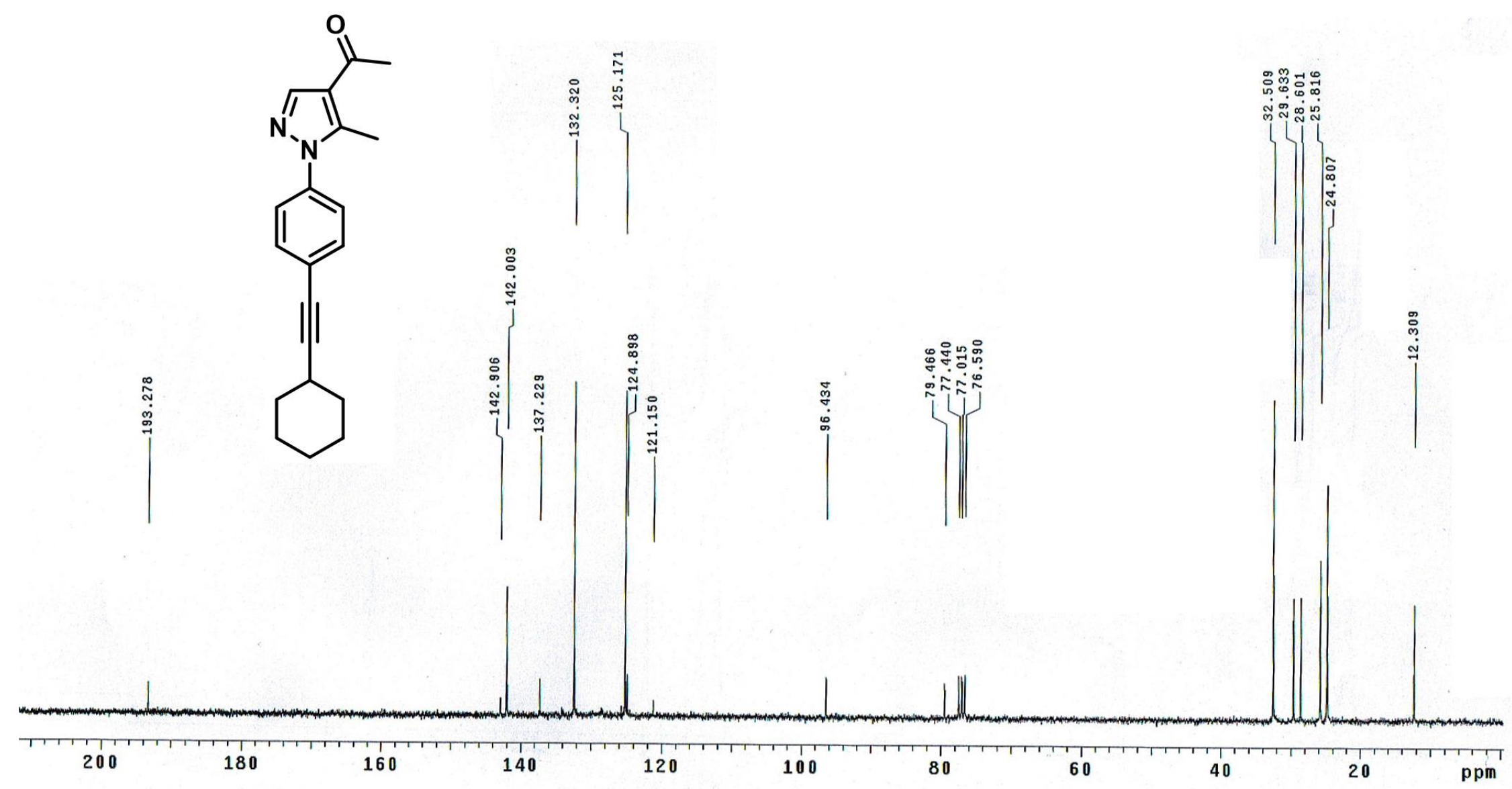

${ }^{13} \mathrm{C}$ NMR of compound 9 


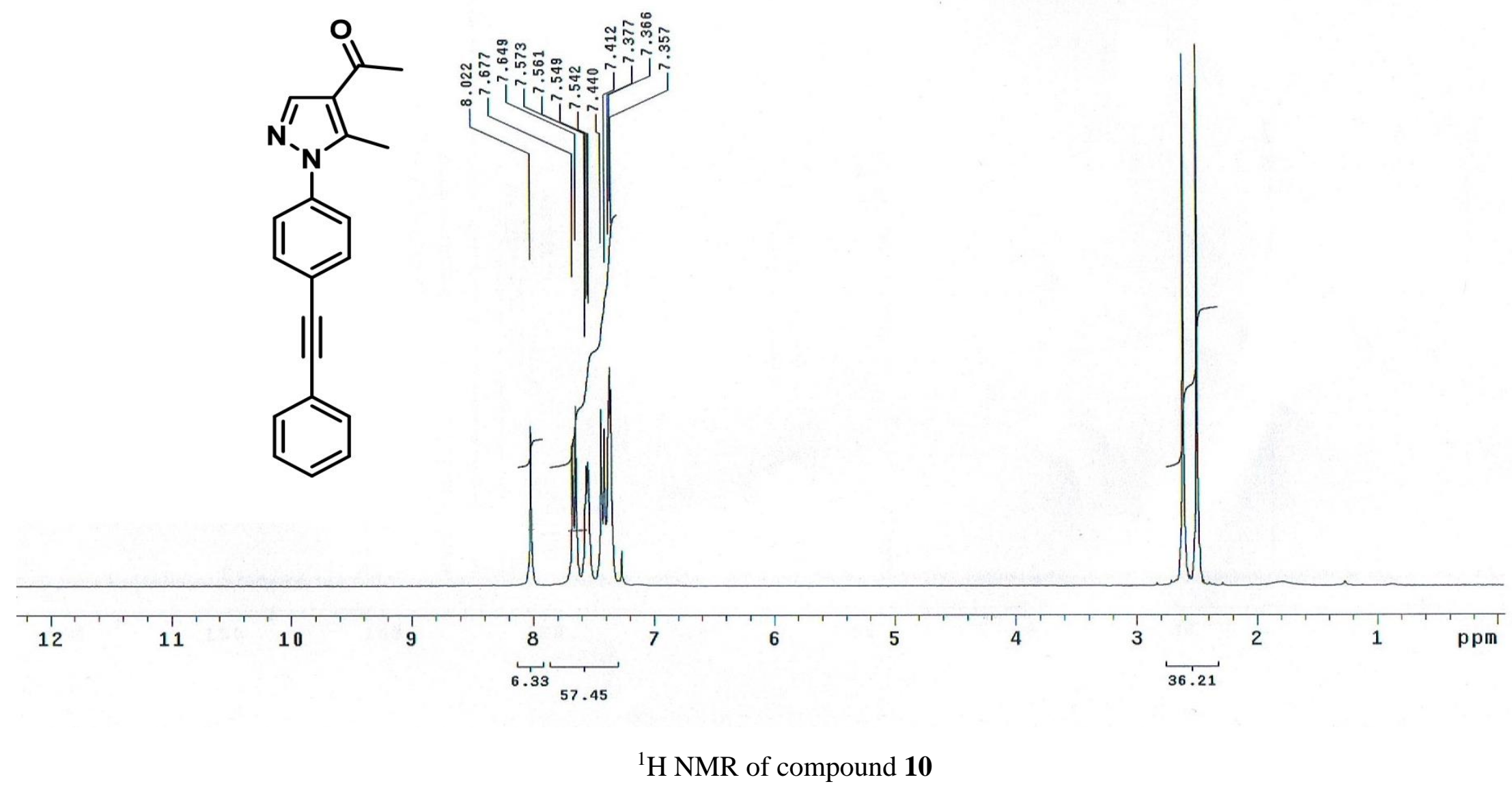




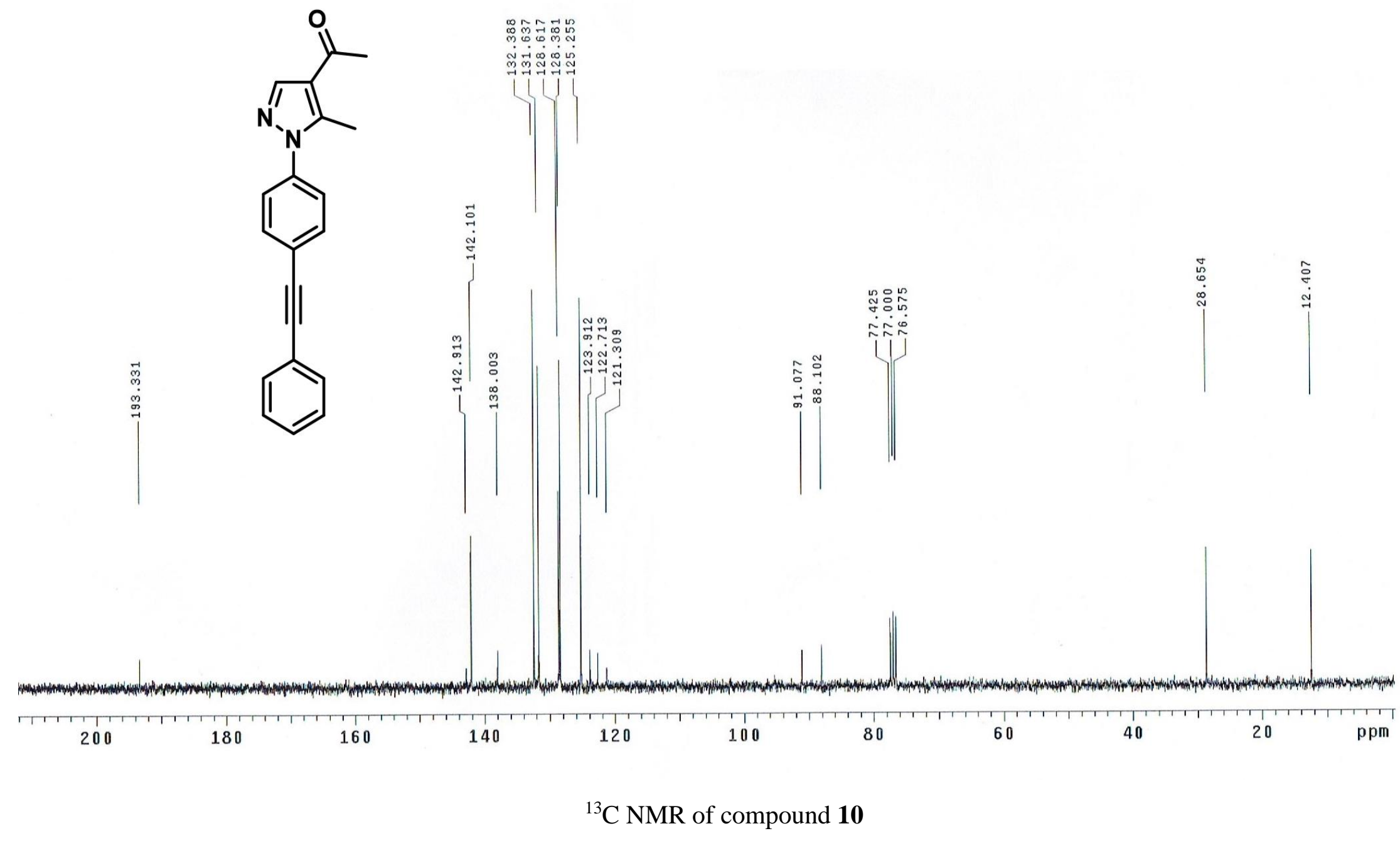




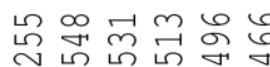

10

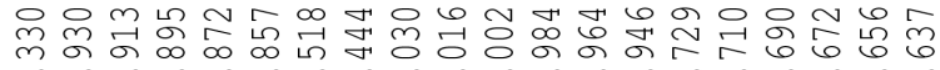
$\dot{\sim} \sim \dot{\sim} \sim \sim \sim \sim \sim \sim \sim \sim \sim \sim \dot{\sim} \sim \dot{\sim} \dot{\sim} \dot{\sim} \dot{\sim}$
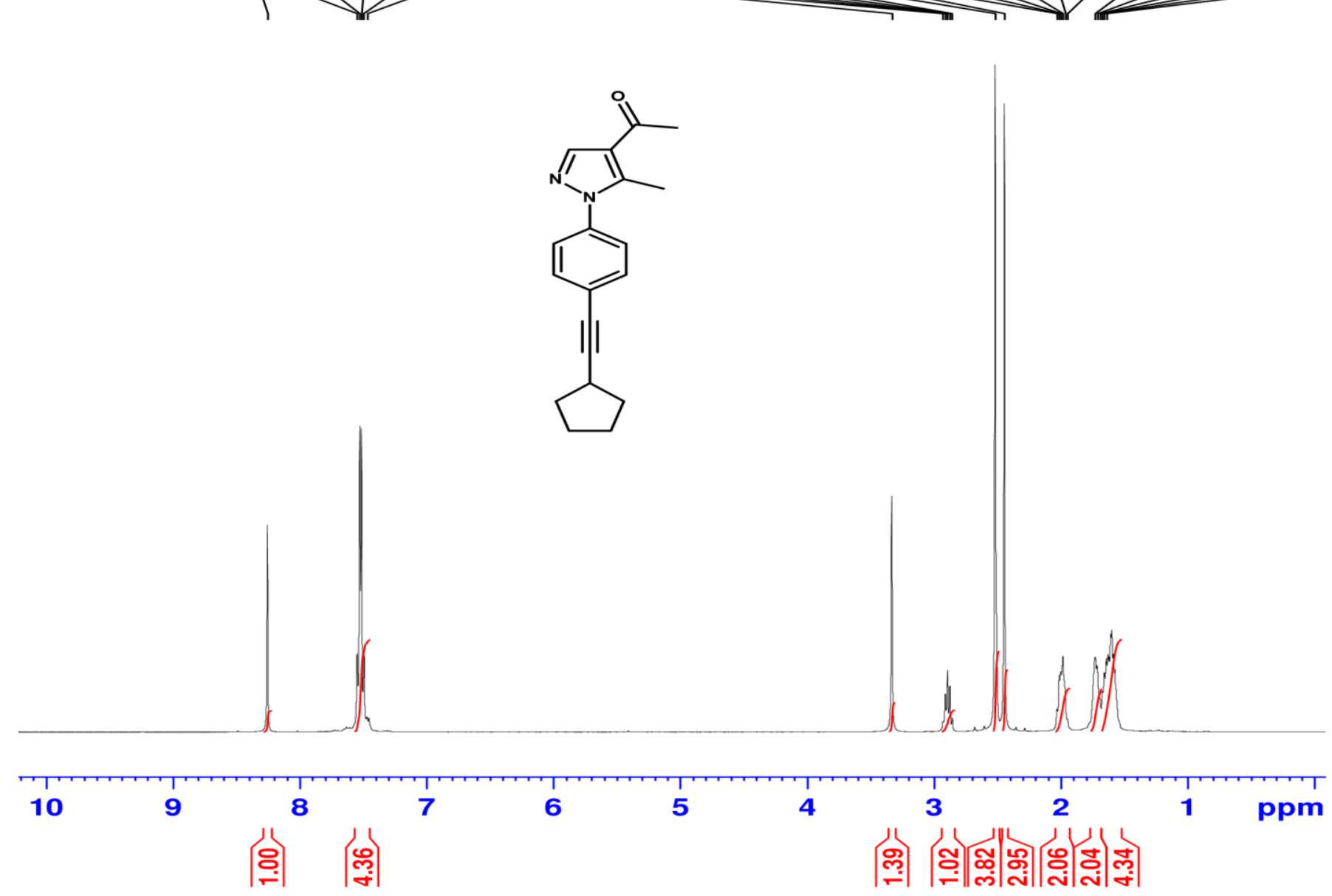

${ }^{1} \mathrm{H}$ NMR of compound $\mathbf{1 1}$ 


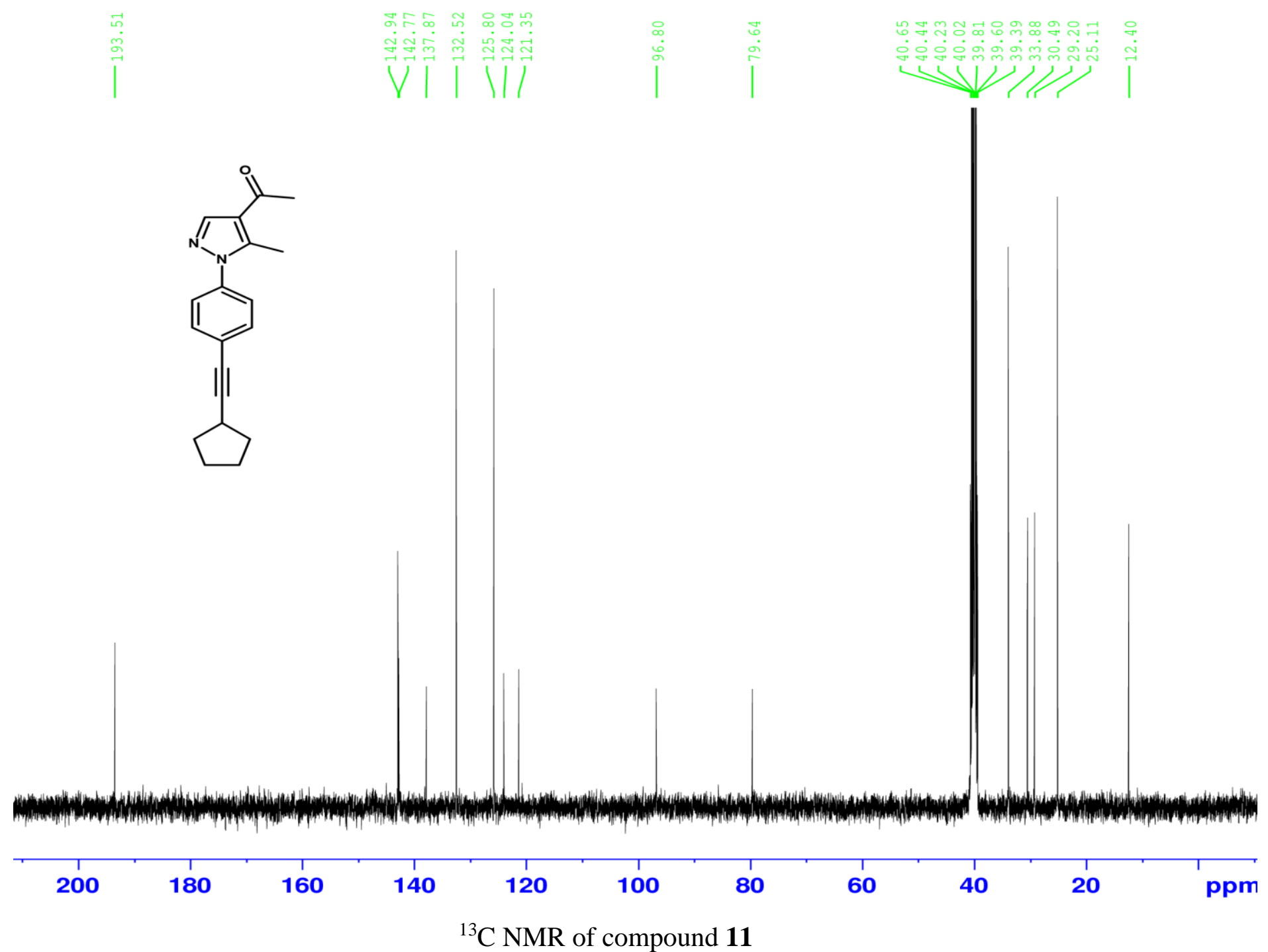




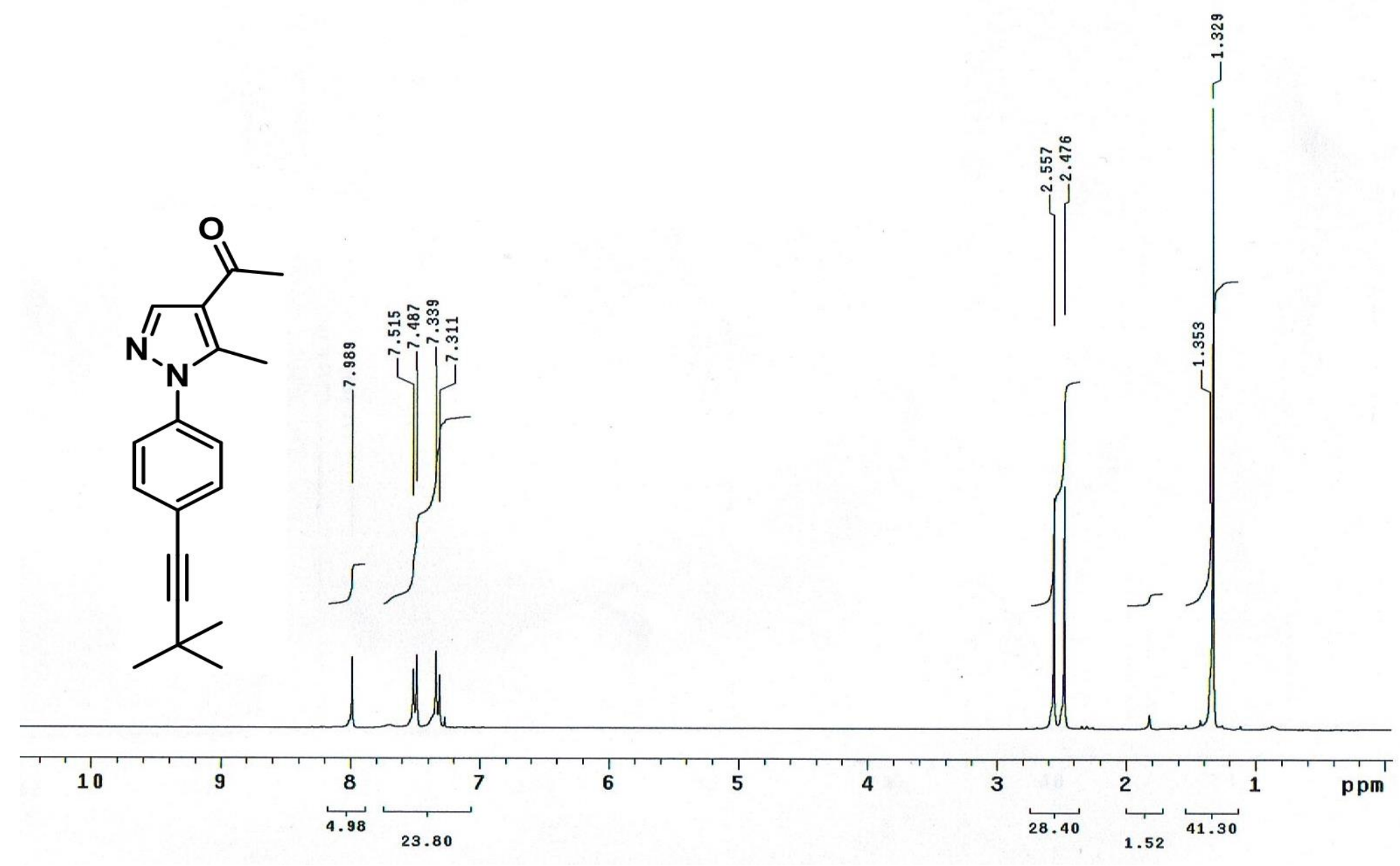

${ }^{1} \mathrm{H}$ NMR of compound 12 


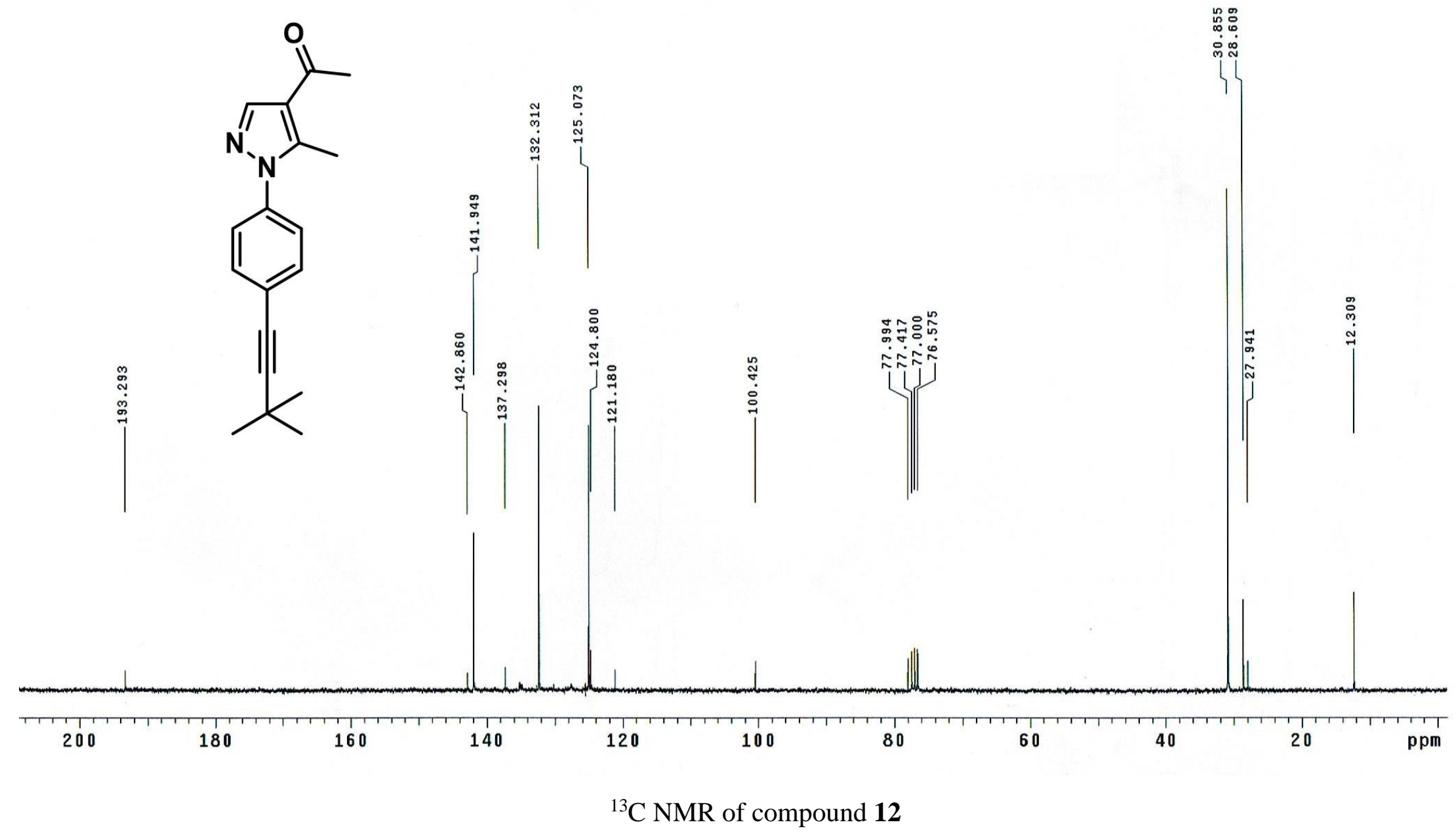




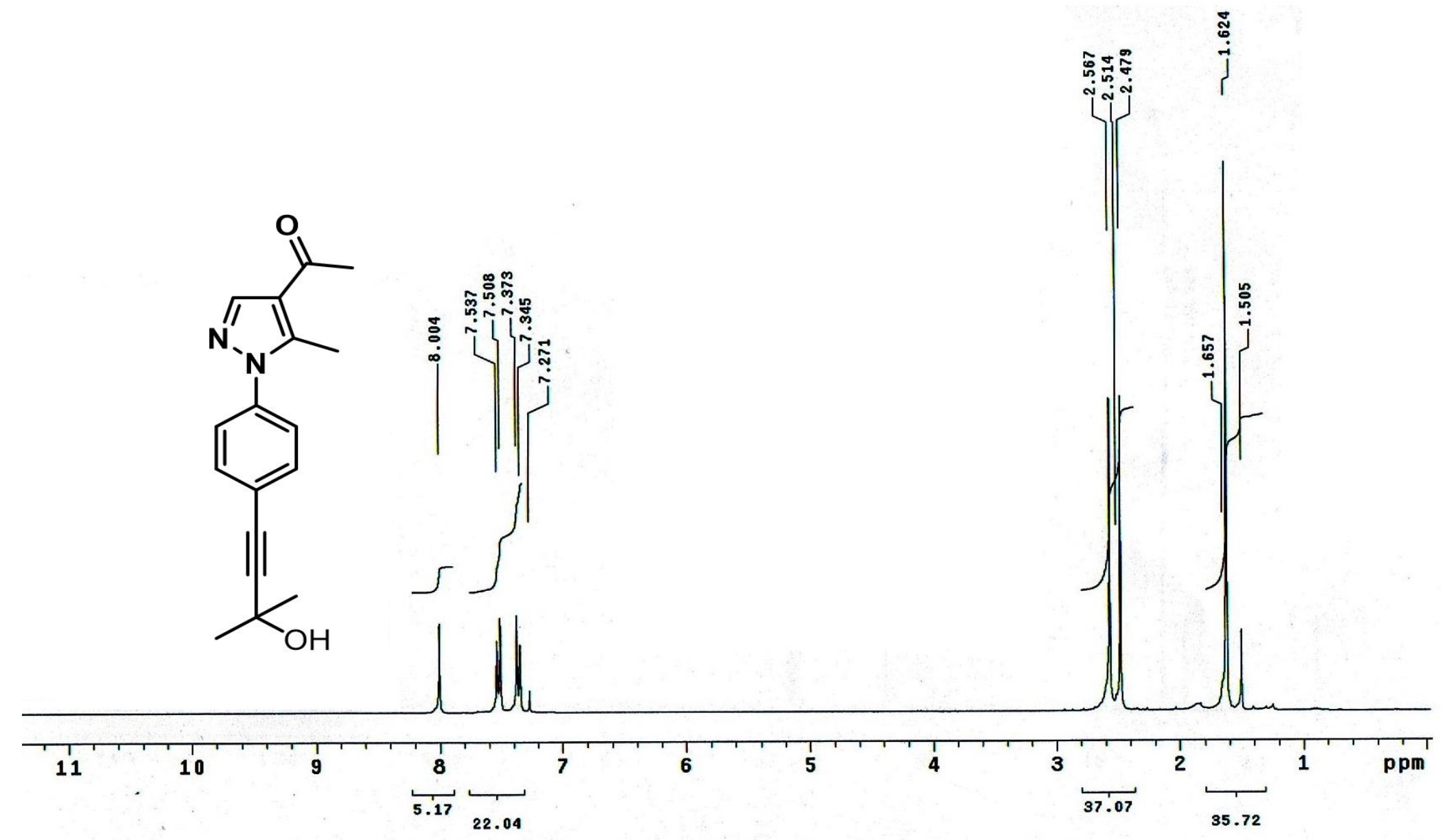

${ }^{1} \mathrm{H}$ NMR of compound $\mathbf{1 3}$ 


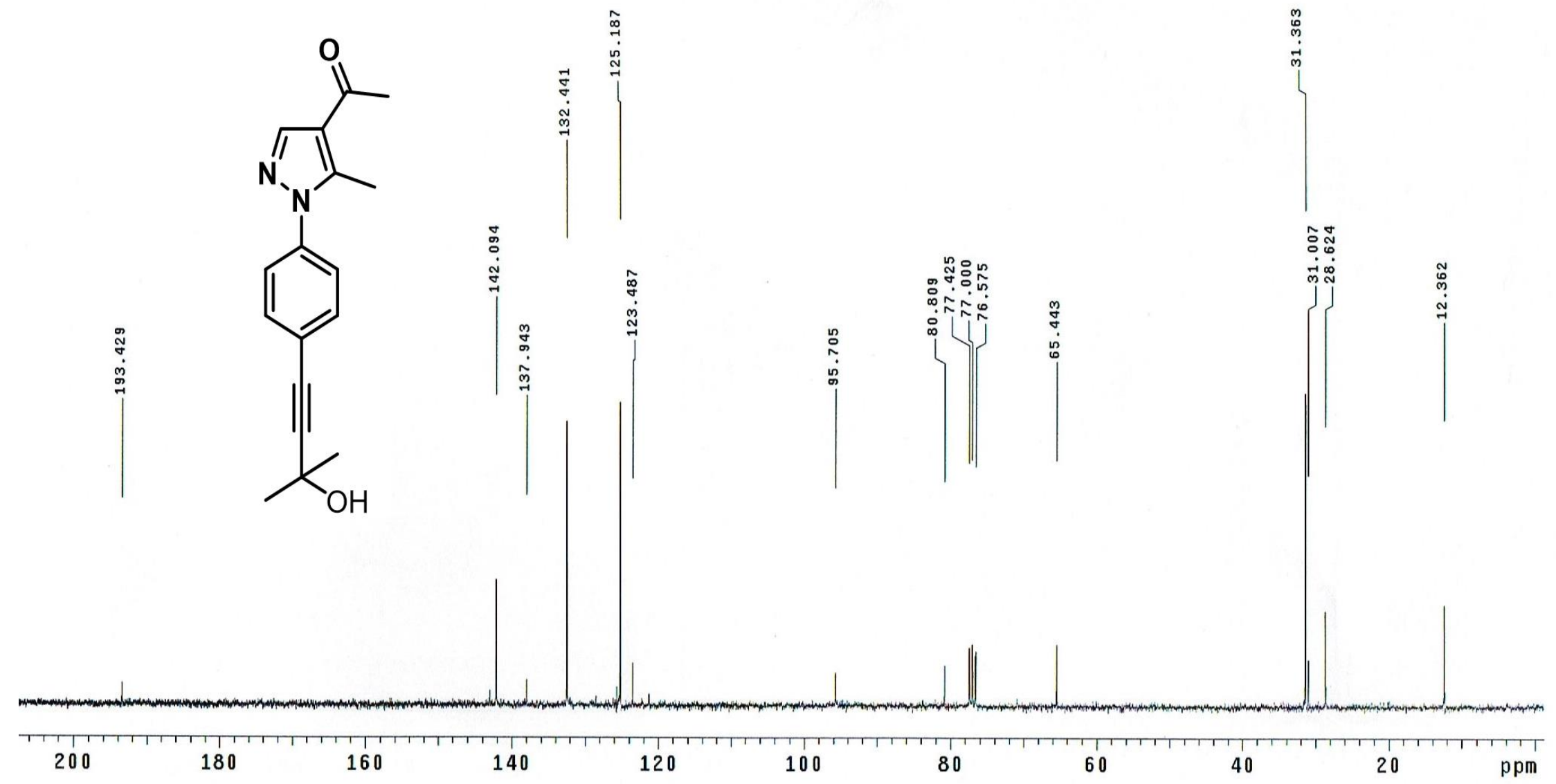

${ }^{13} \mathrm{C}$ NMR of compound $\mathbf{1 3}$ 


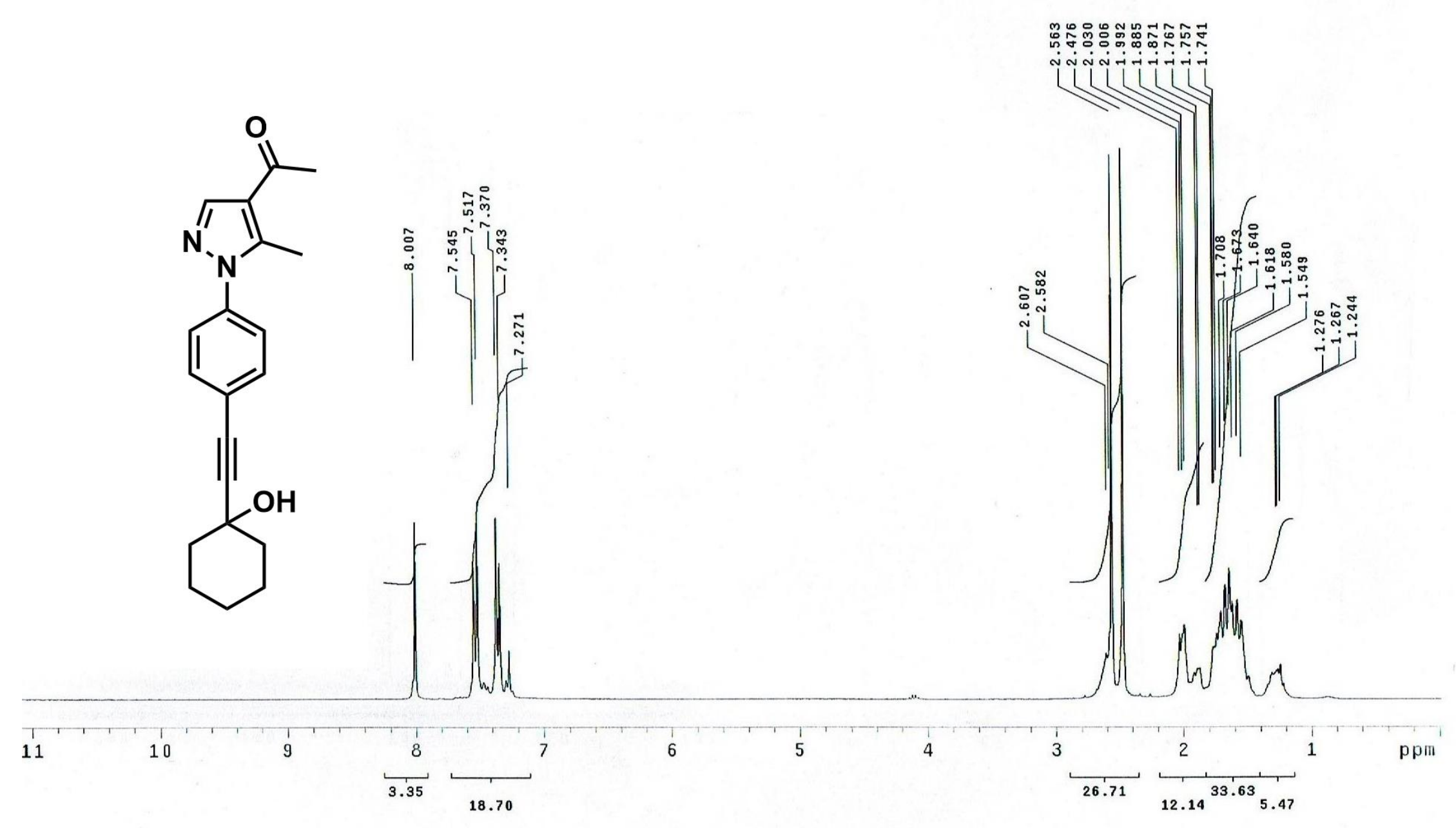

${ }^{1} \mathrm{H}$ NMR of compound 14 


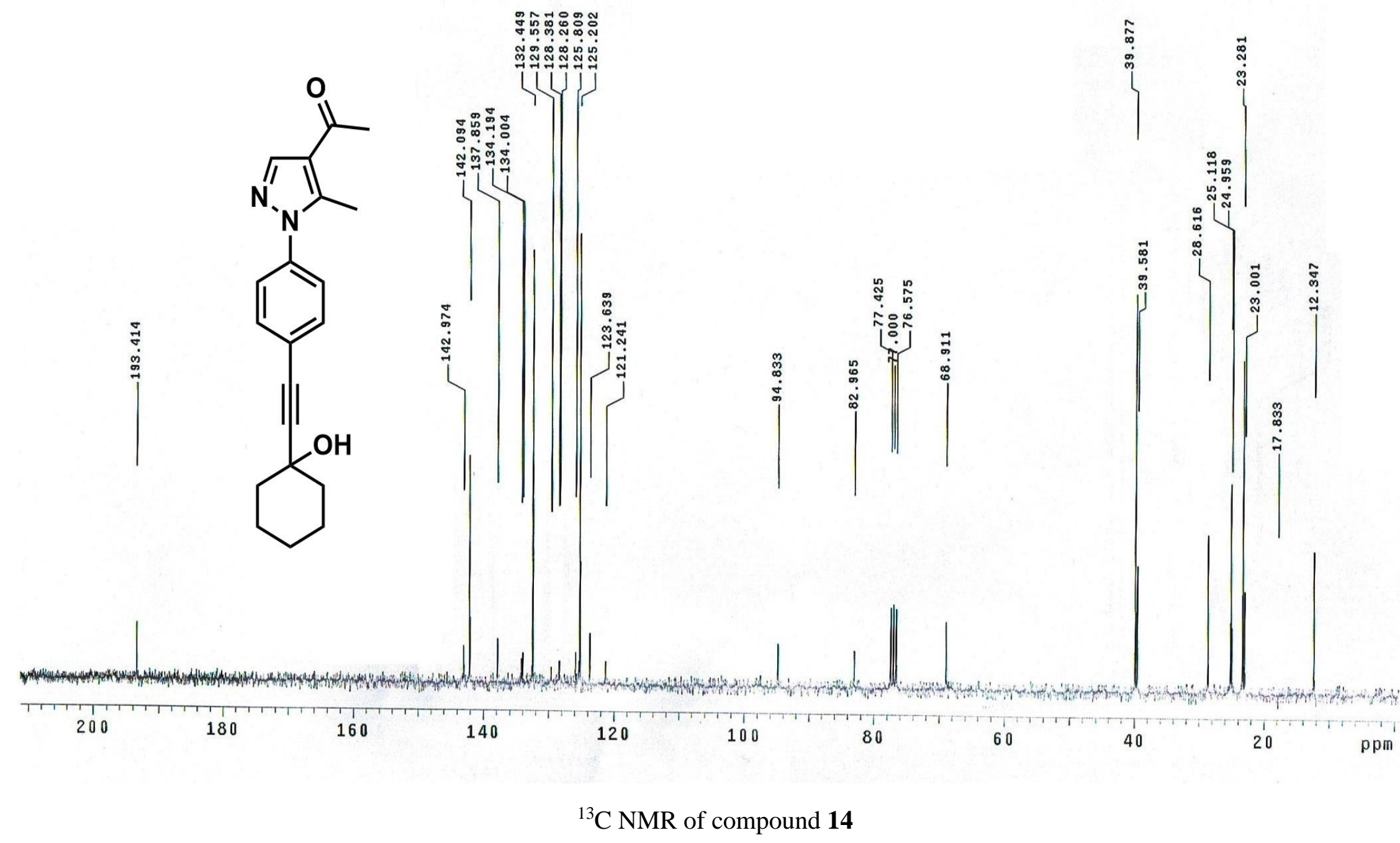




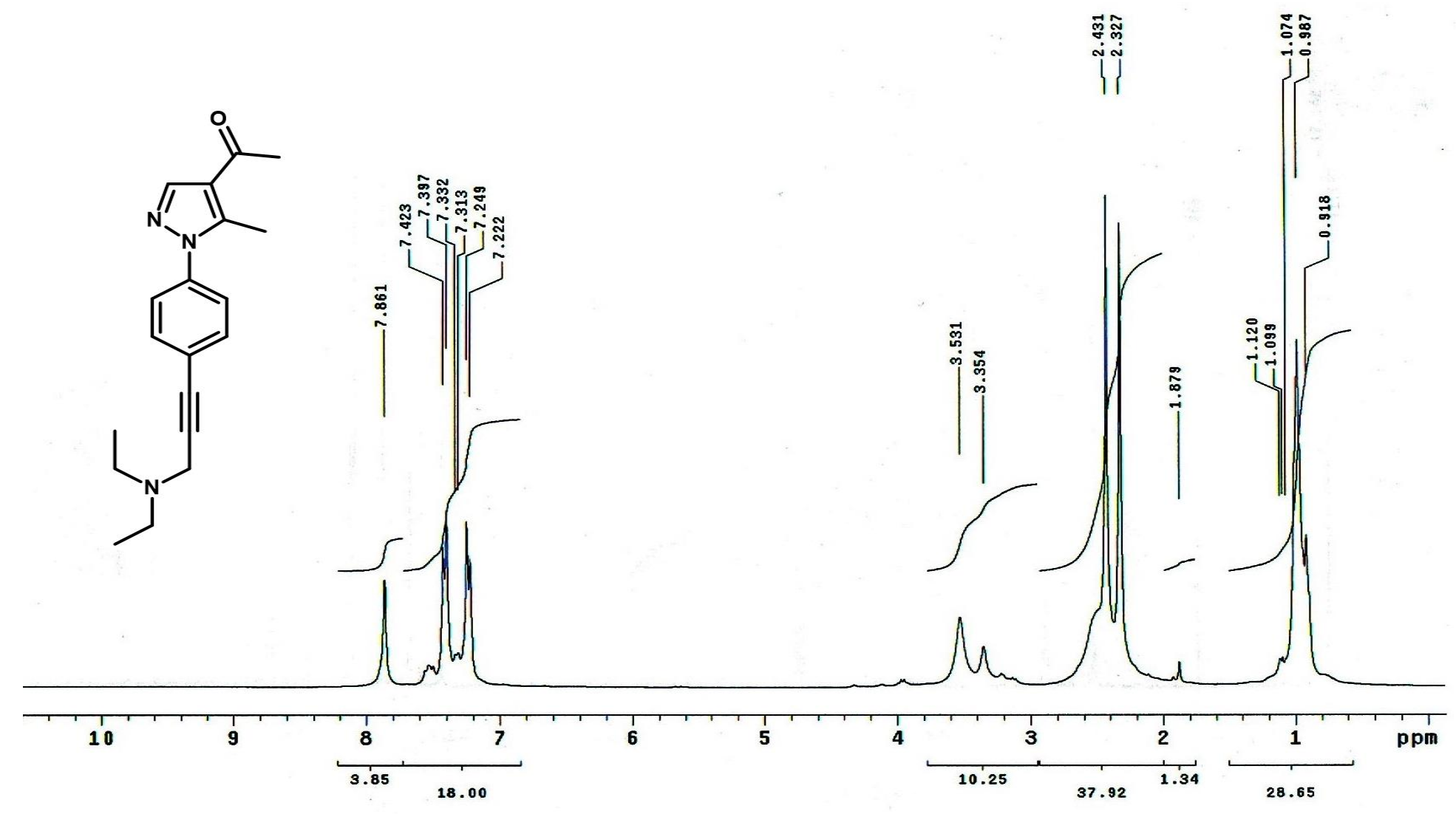

${ }^{1} \mathrm{H}$ NMR of compound $\mathbf{1 5}$ 


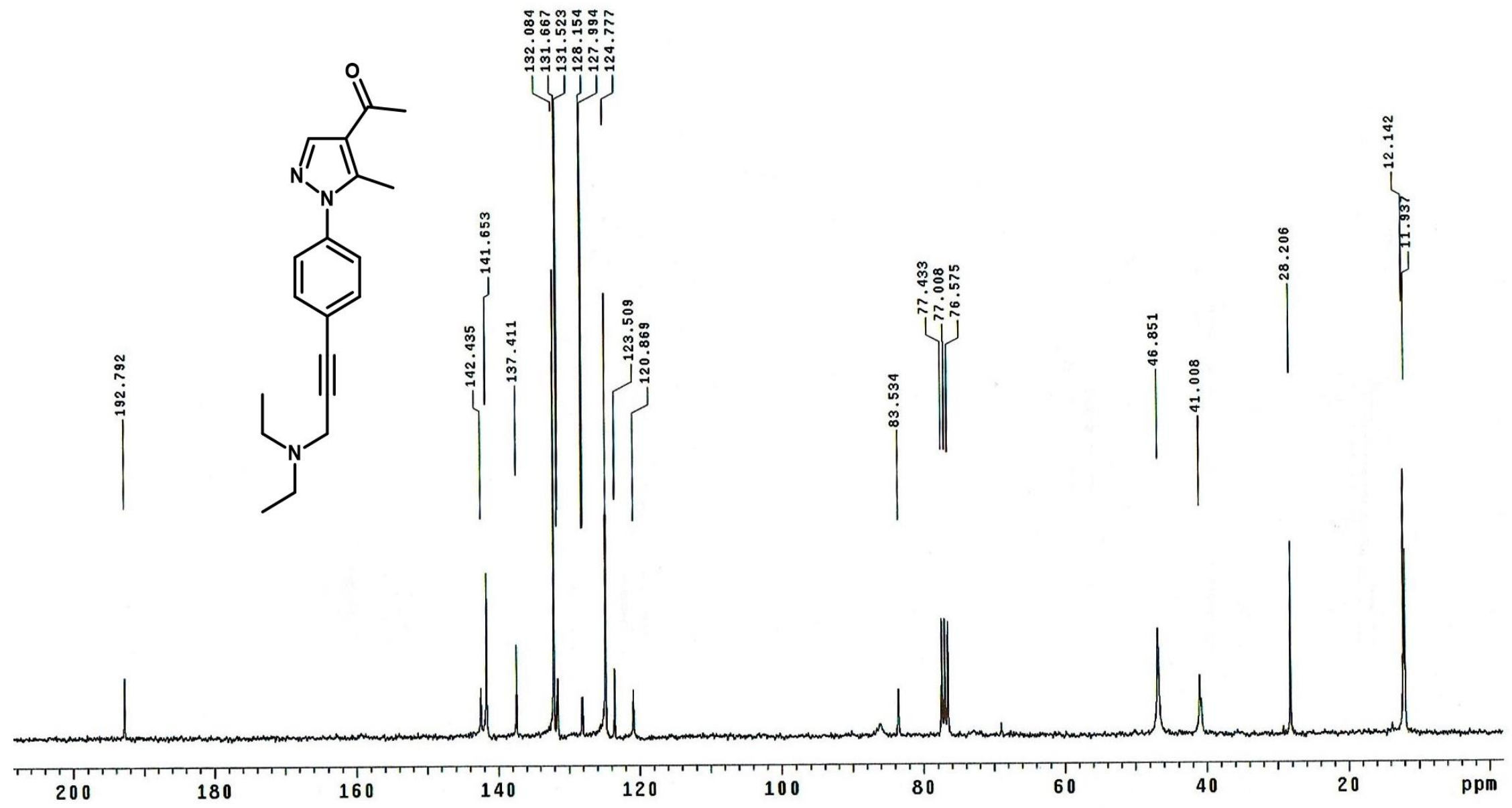

${ }^{13} \mathrm{C}$ NMR of compound 15

S46 


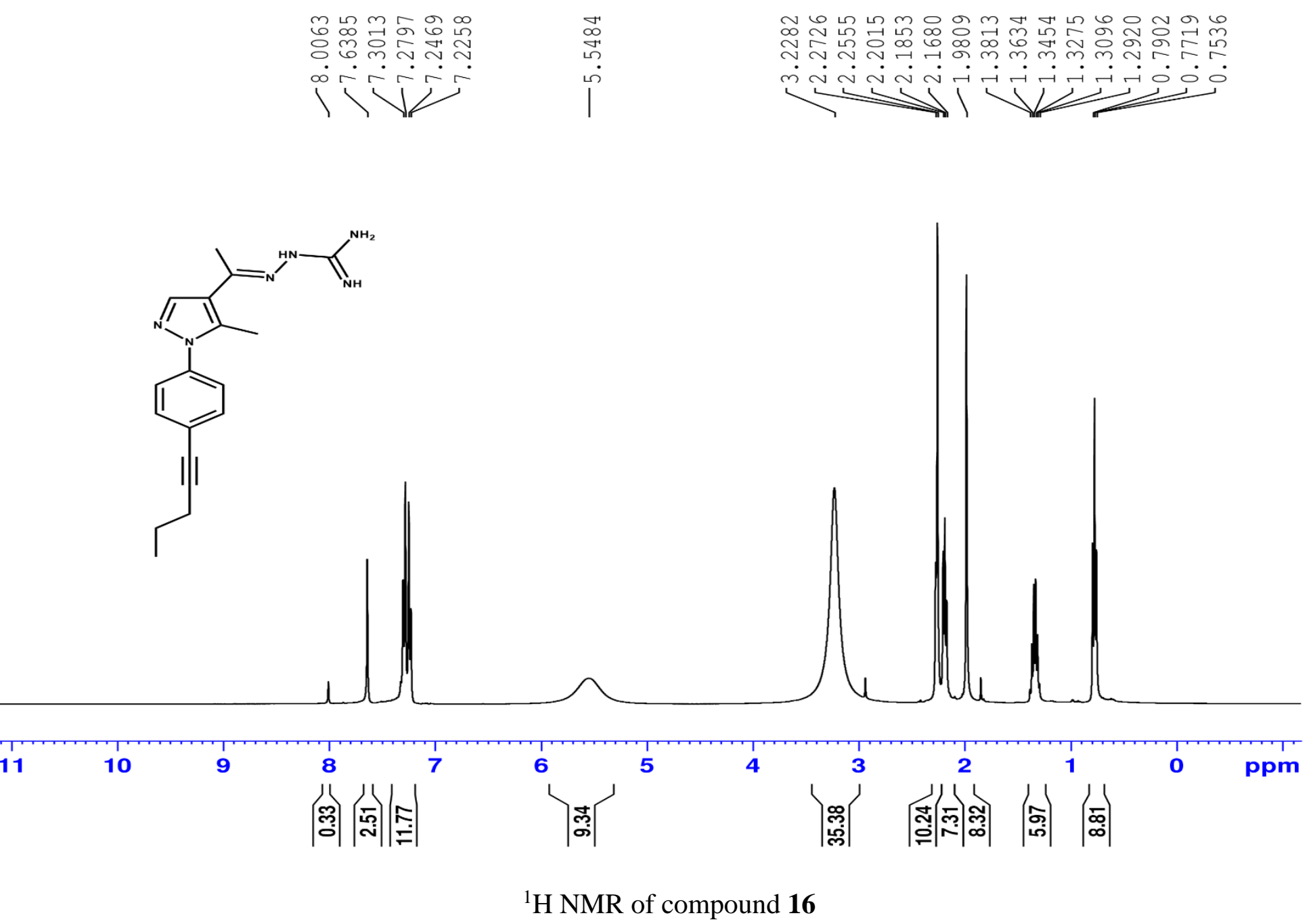




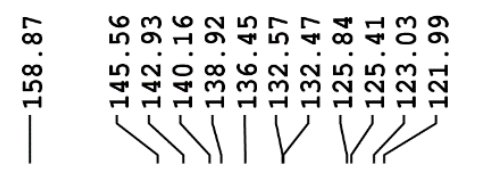

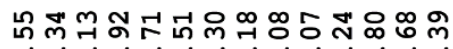
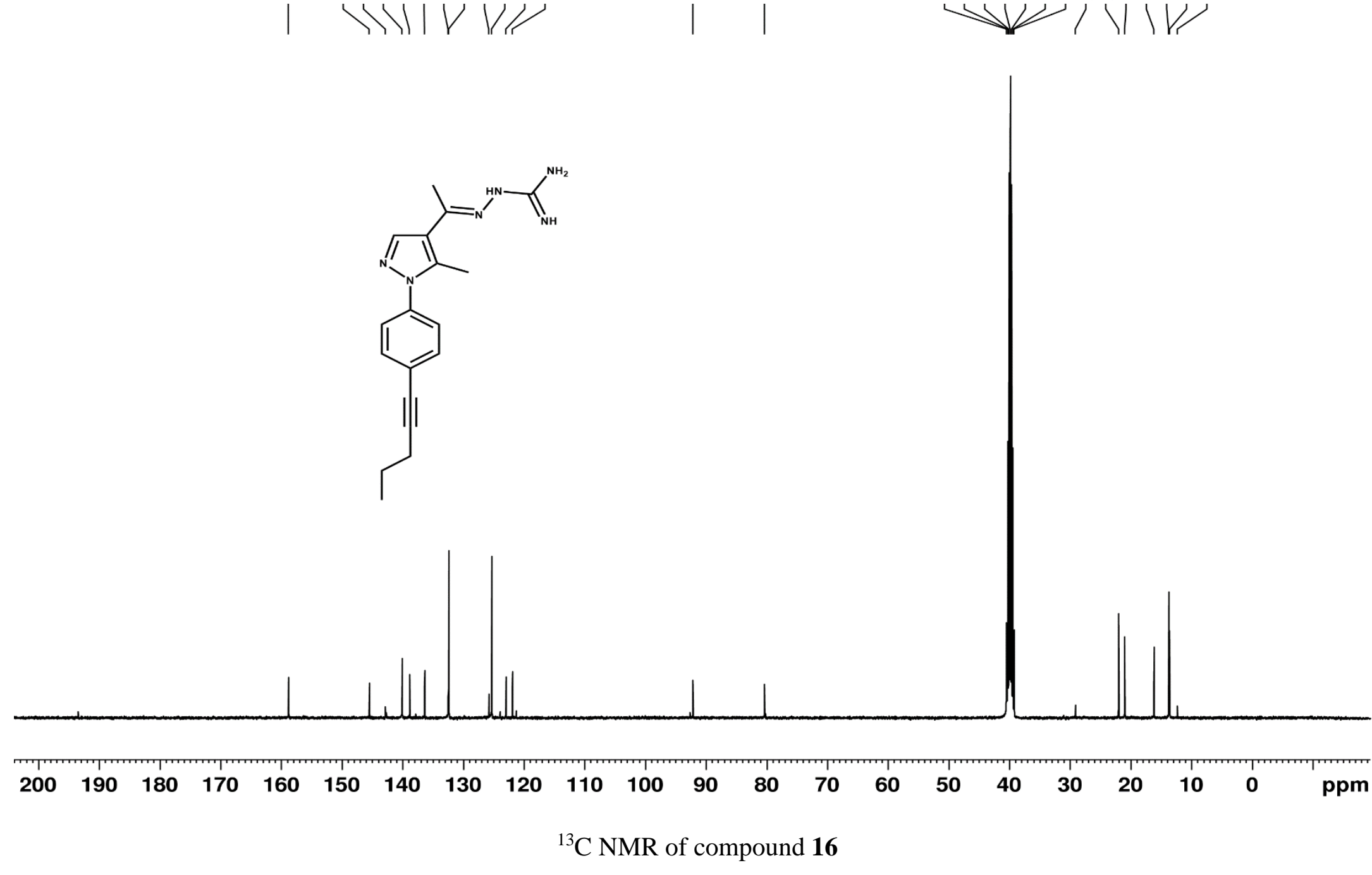


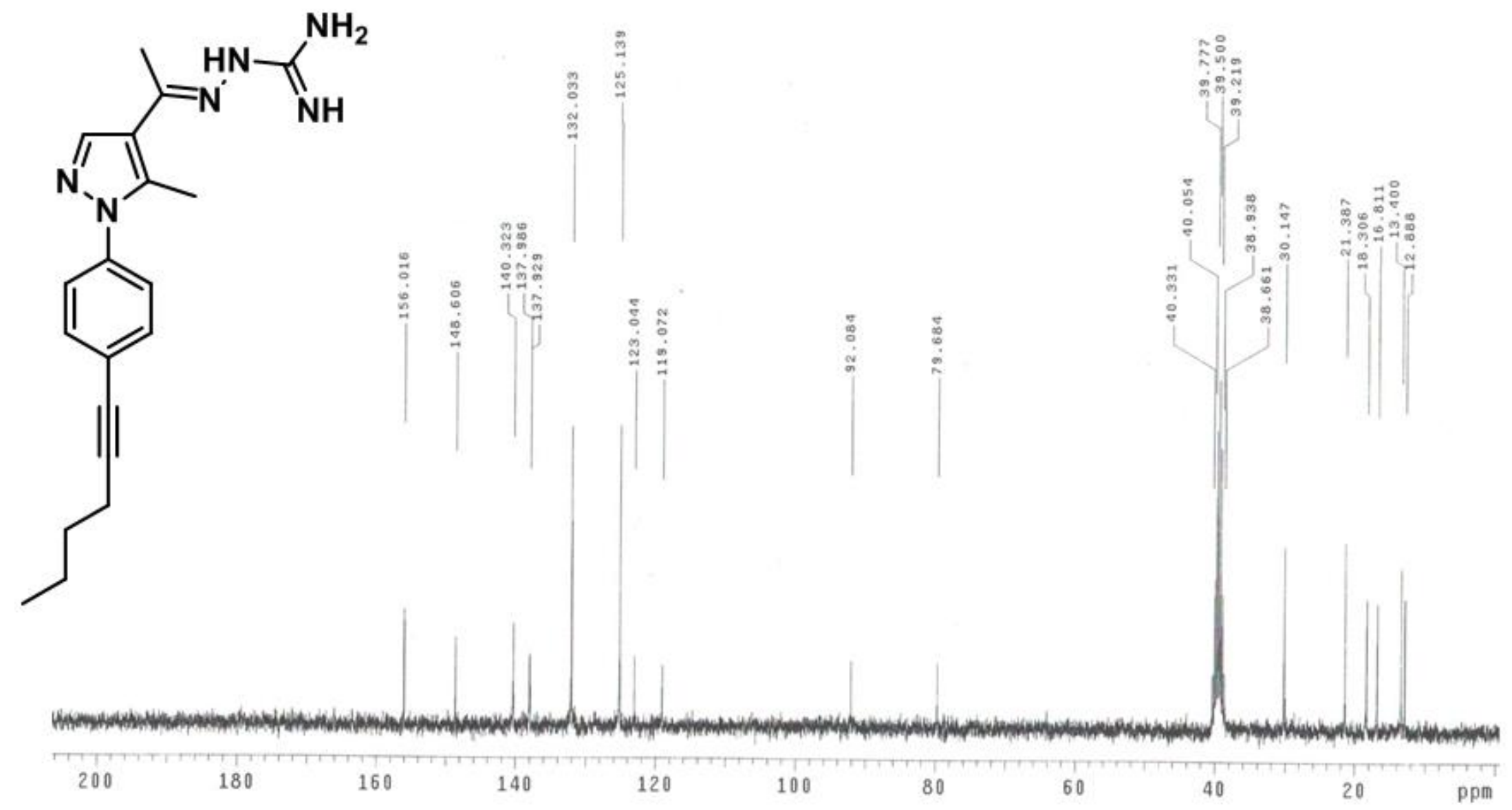




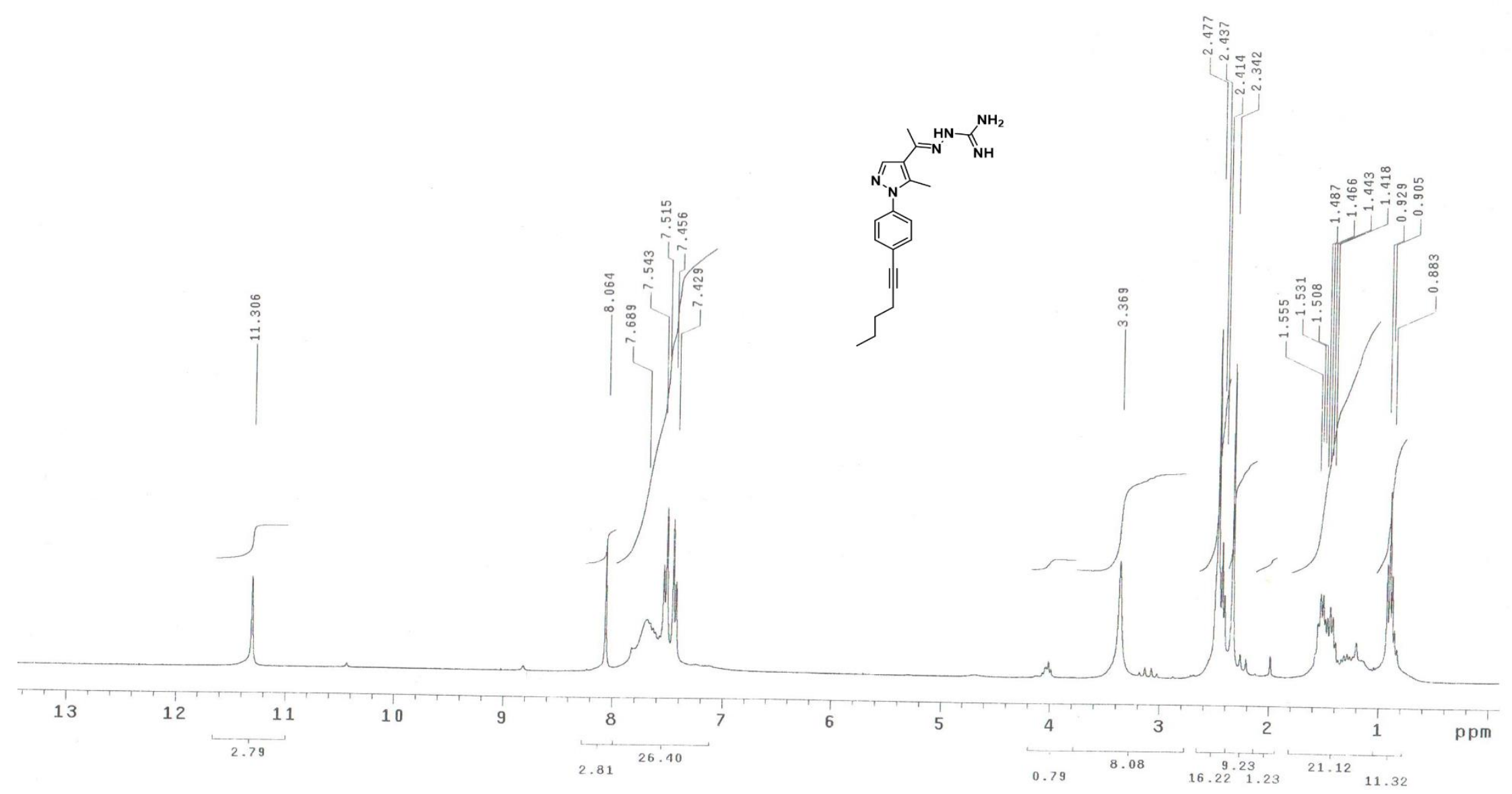

${ }^{1} \mathrm{H}$ NMR of compound $\mathbf{1 7}$ 


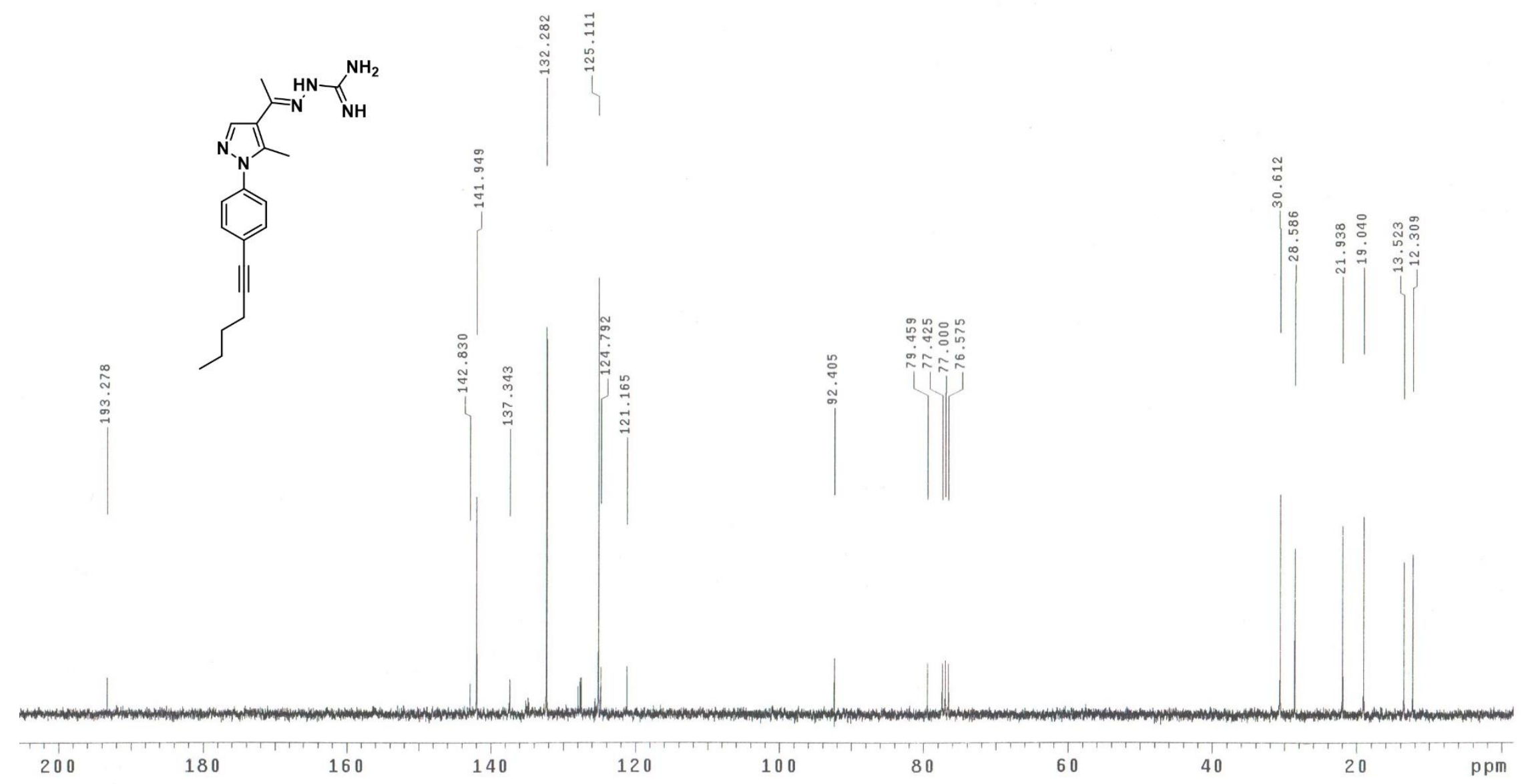

${ }^{13} \mathrm{C}$ NMR of compound $\mathbf{1 7}$ 


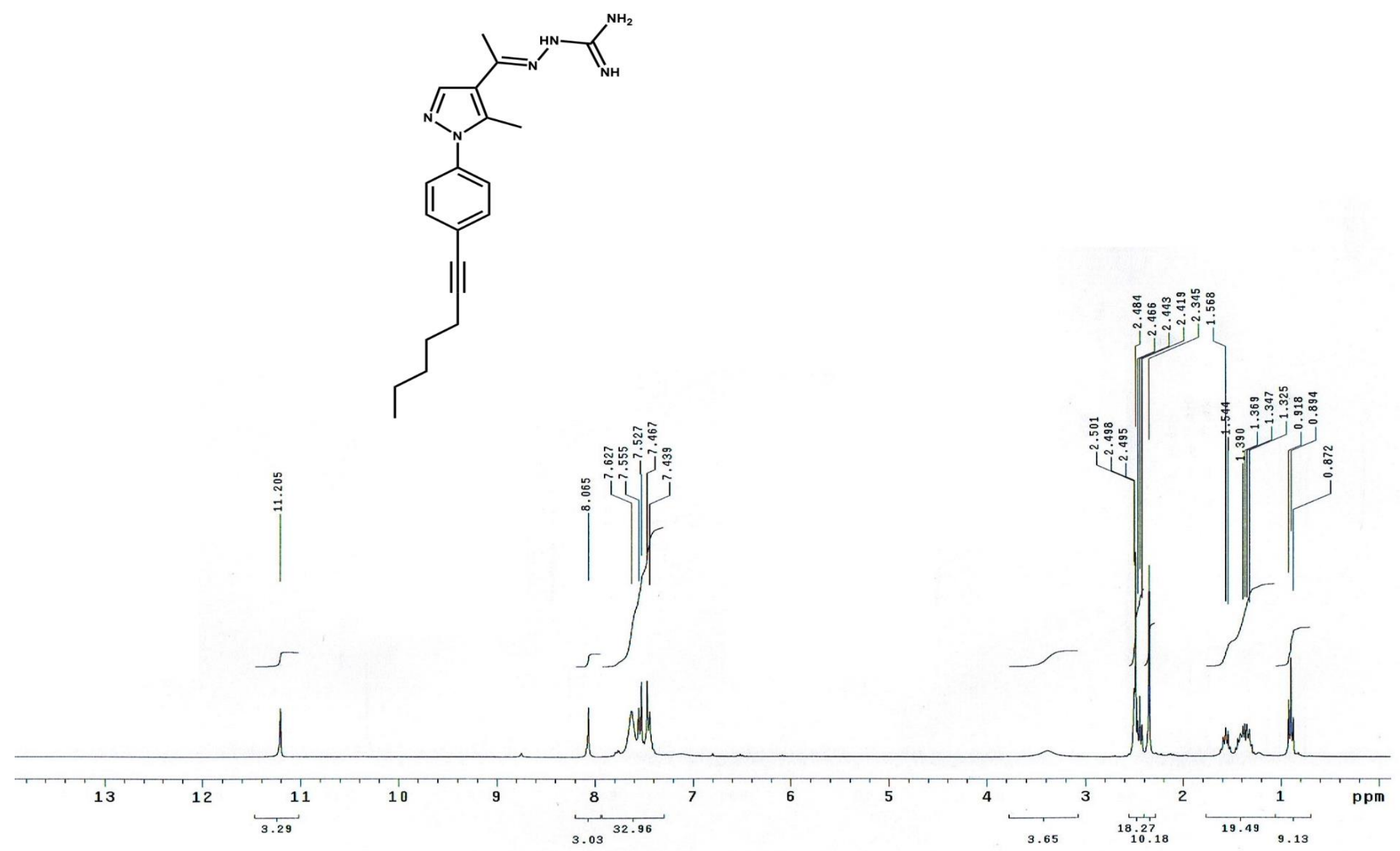

${ }^{1} \mathrm{H}$ NMR of compound $\mathbf{1 8}$ 

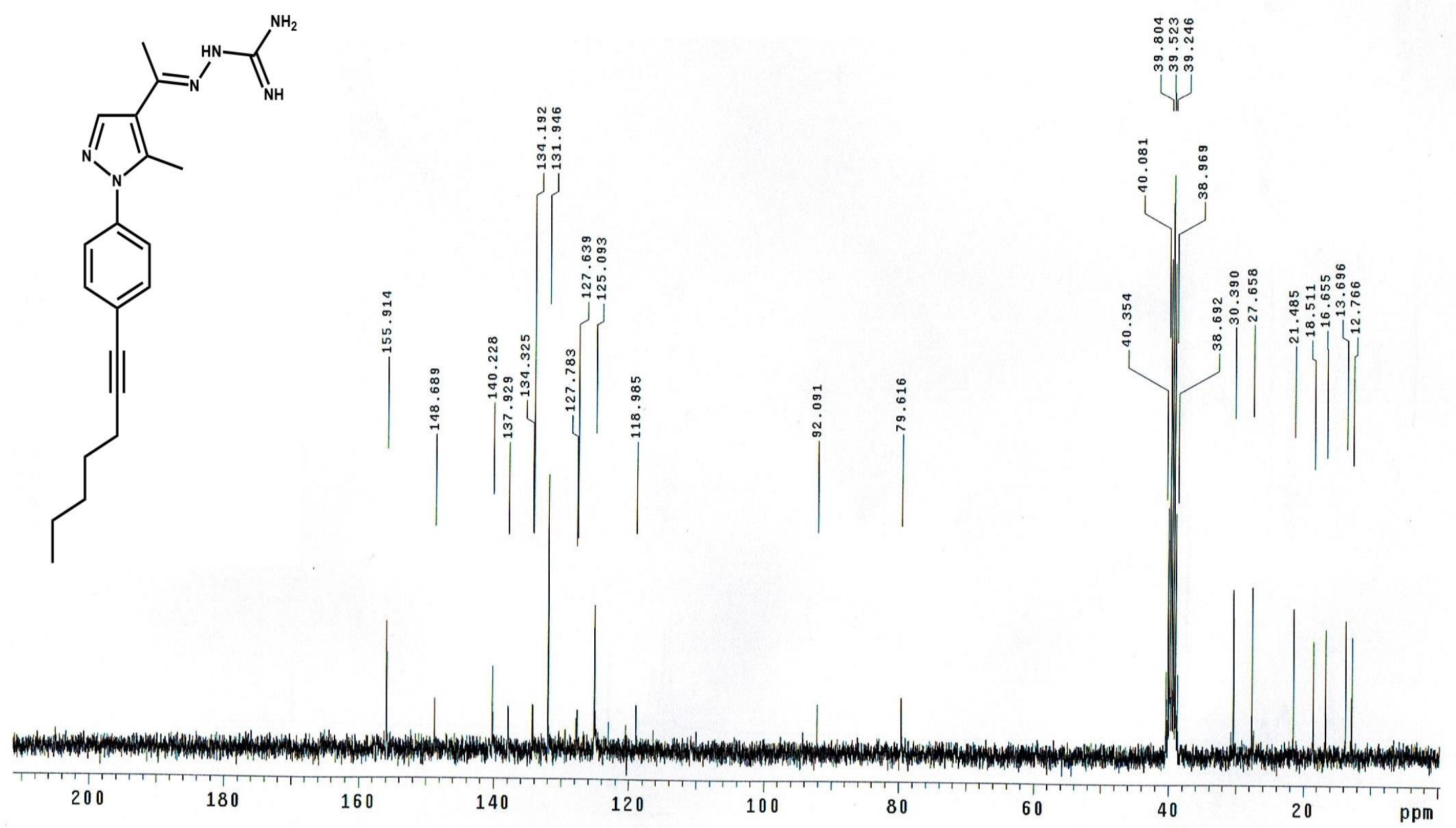

${ }^{13} \mathrm{C}$ NMR of compound $\mathbf{1 8}$ 


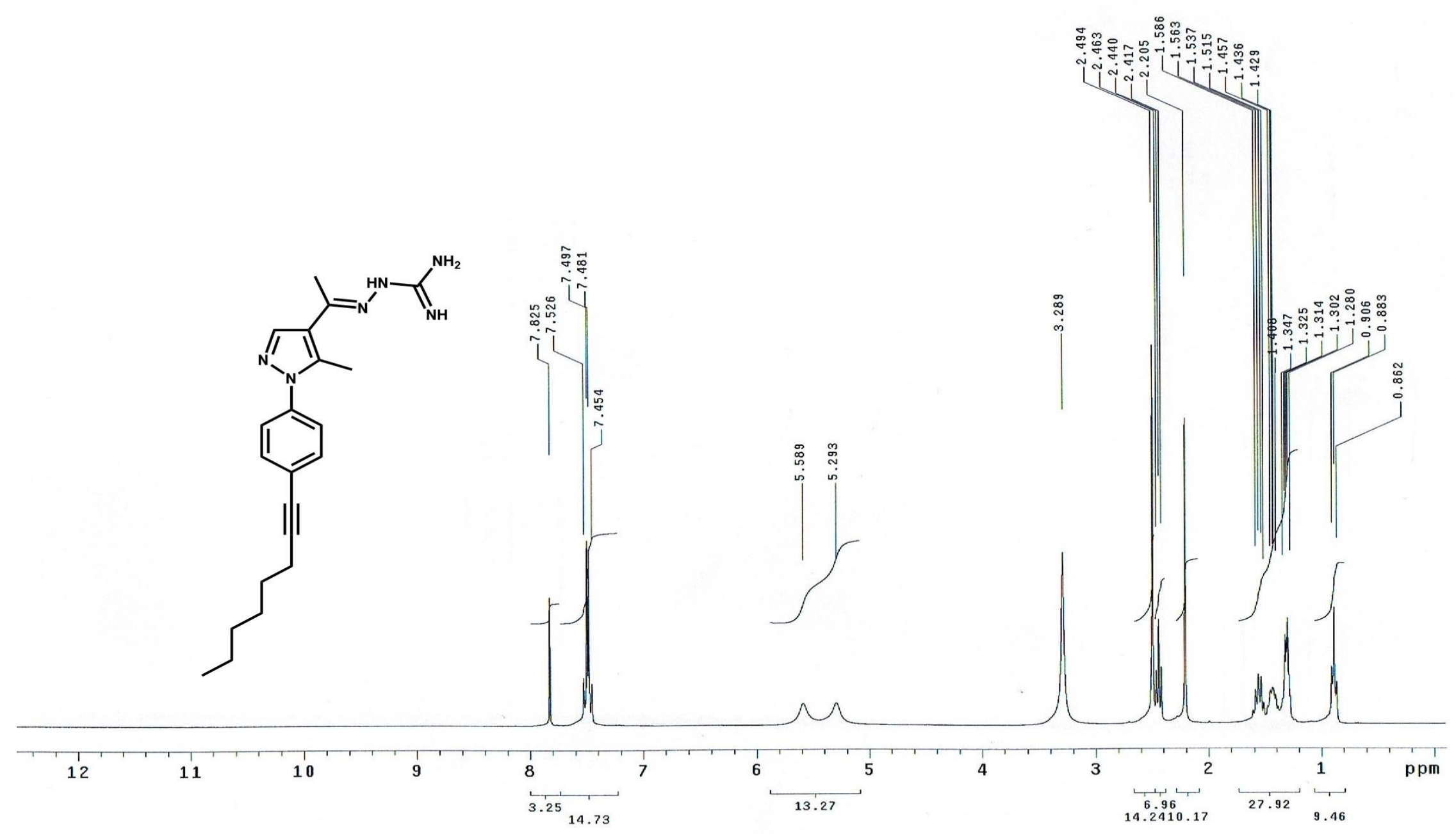

${ }^{1} \mathrm{H}$ NMR of compound 19 


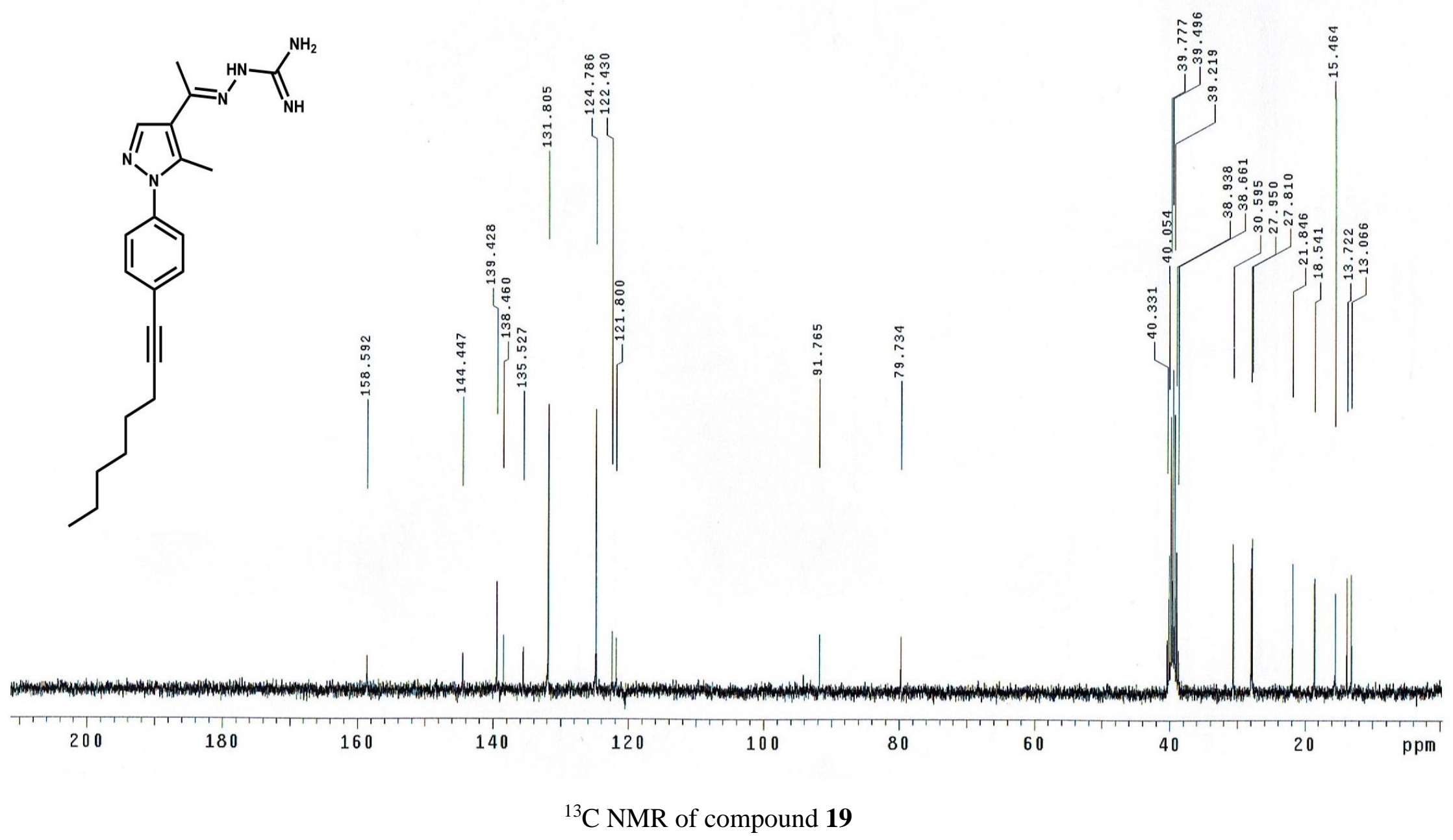




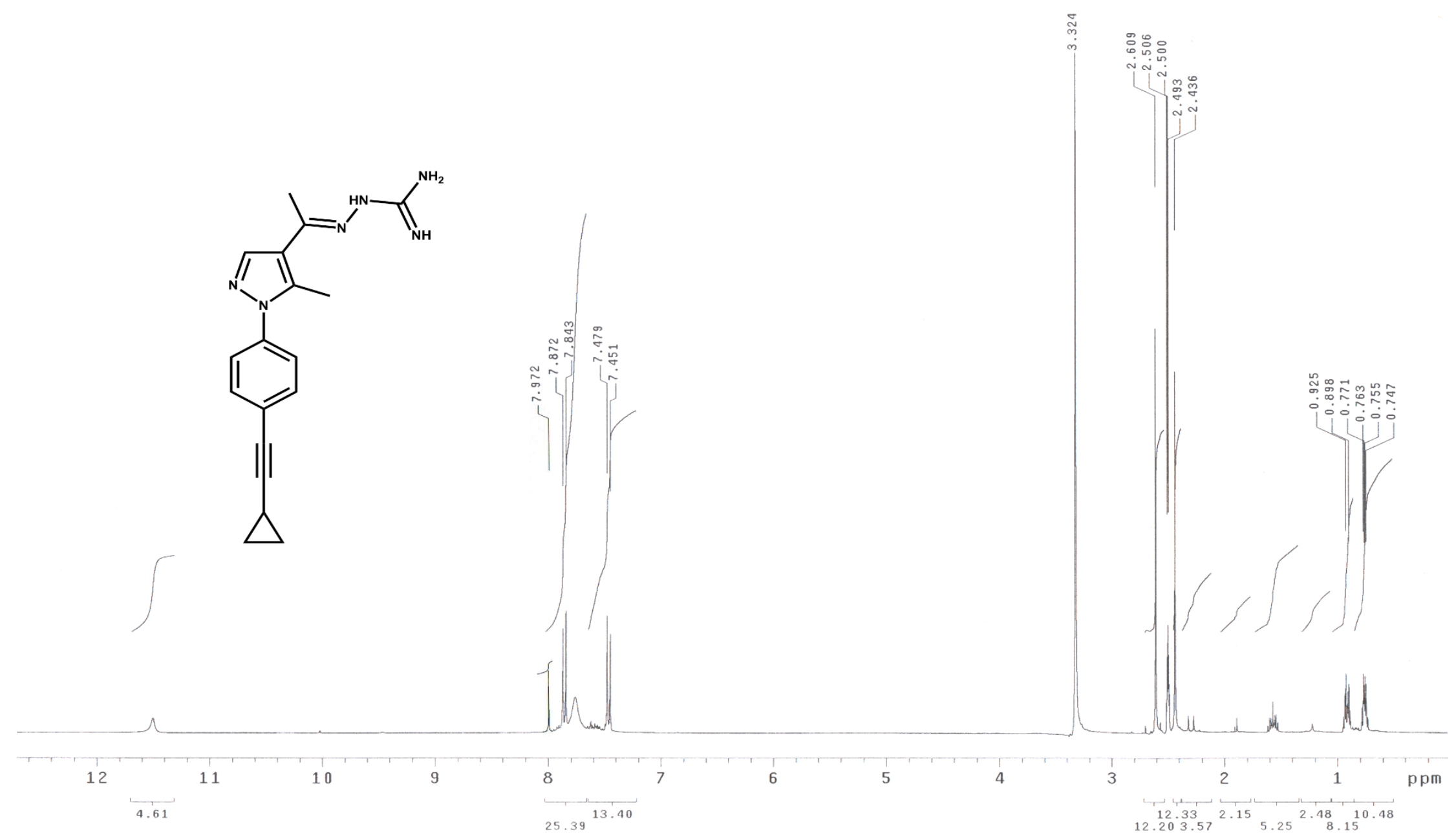

${ }^{1} \mathrm{H}$ NMR of compound 20 

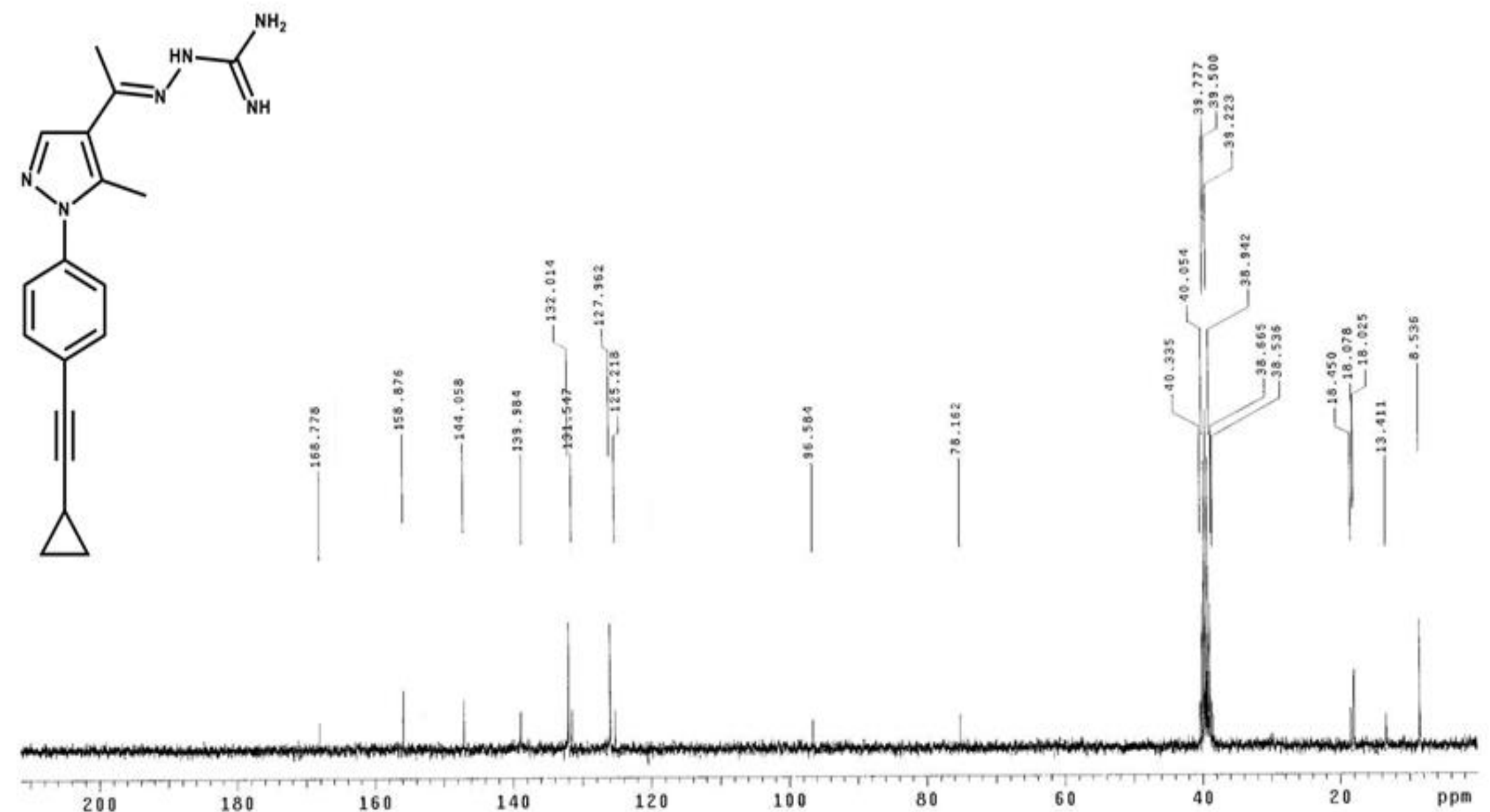

${ }^{13} \mathrm{C}$ NMR of compound 20 


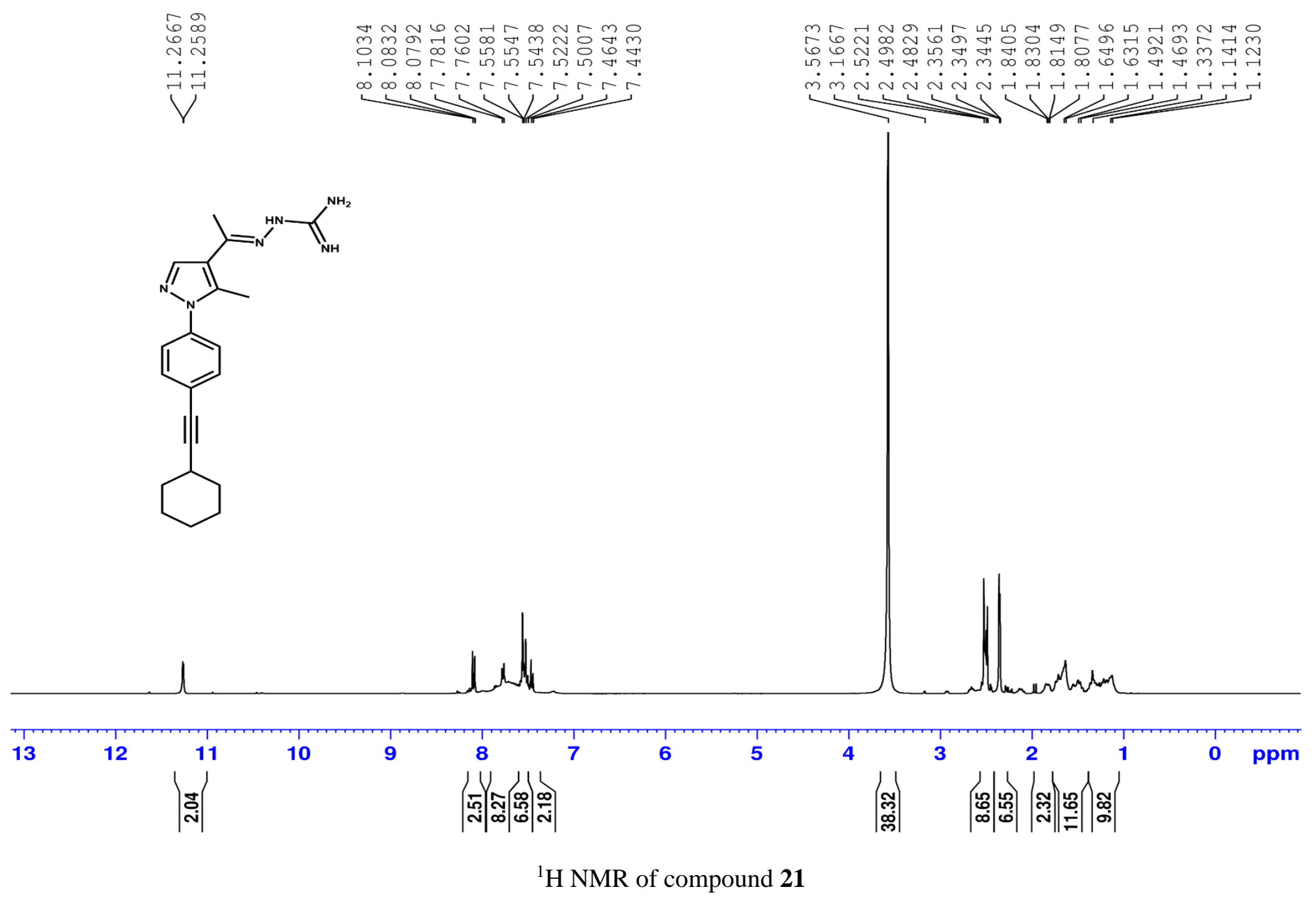



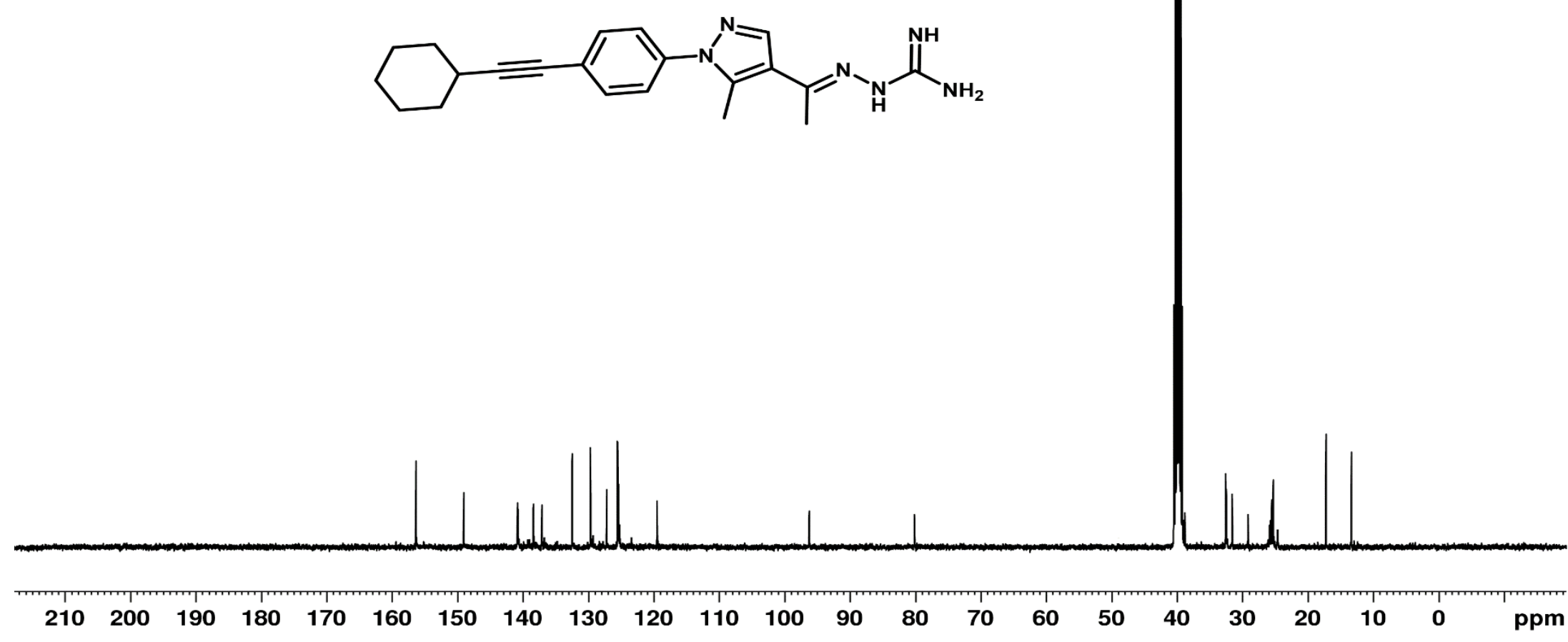

${ }^{13} \mathrm{C}$ NMR of compound 21 


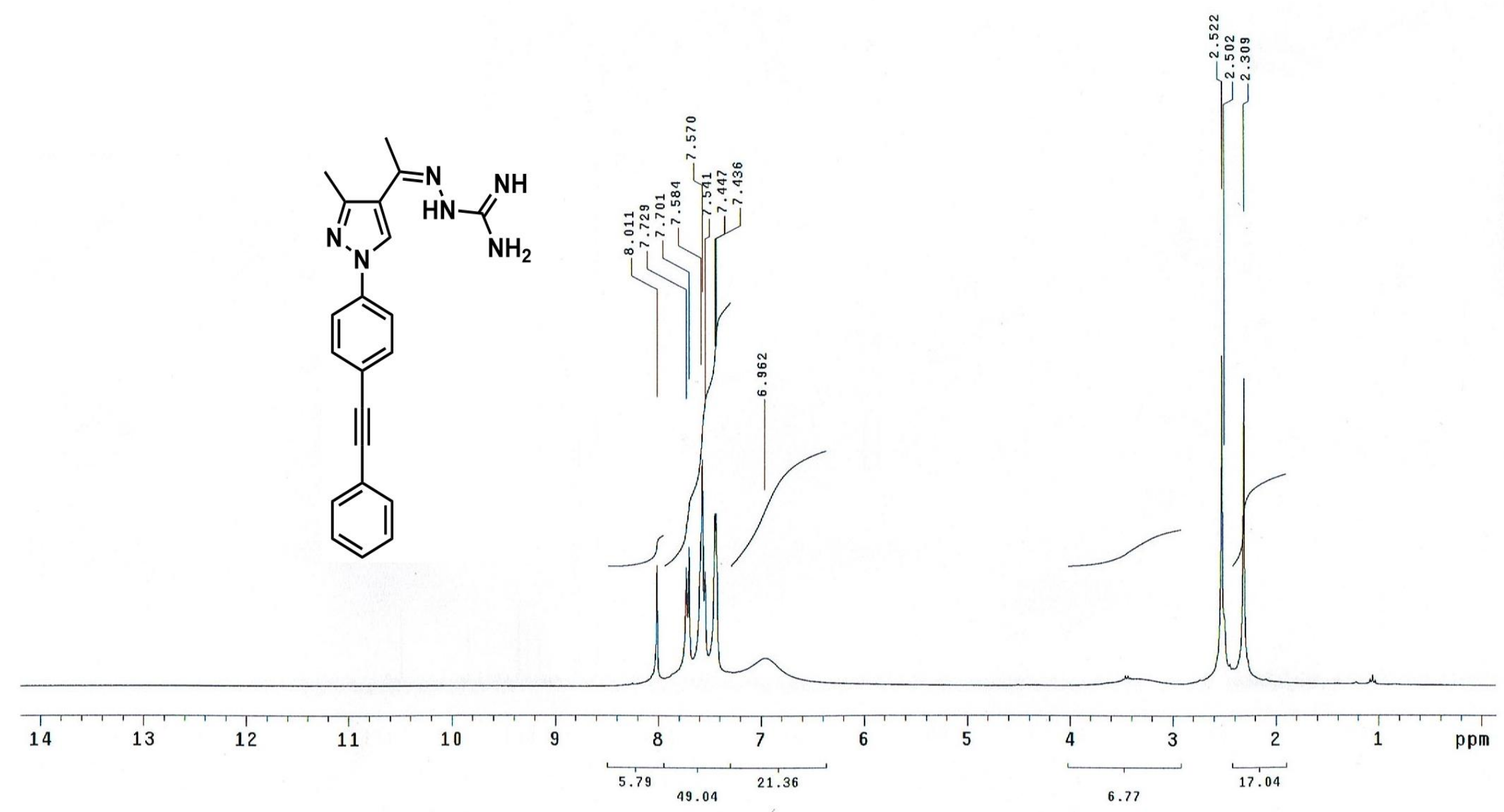

${ }^{1} \mathrm{H}$ NMR of compound 22 


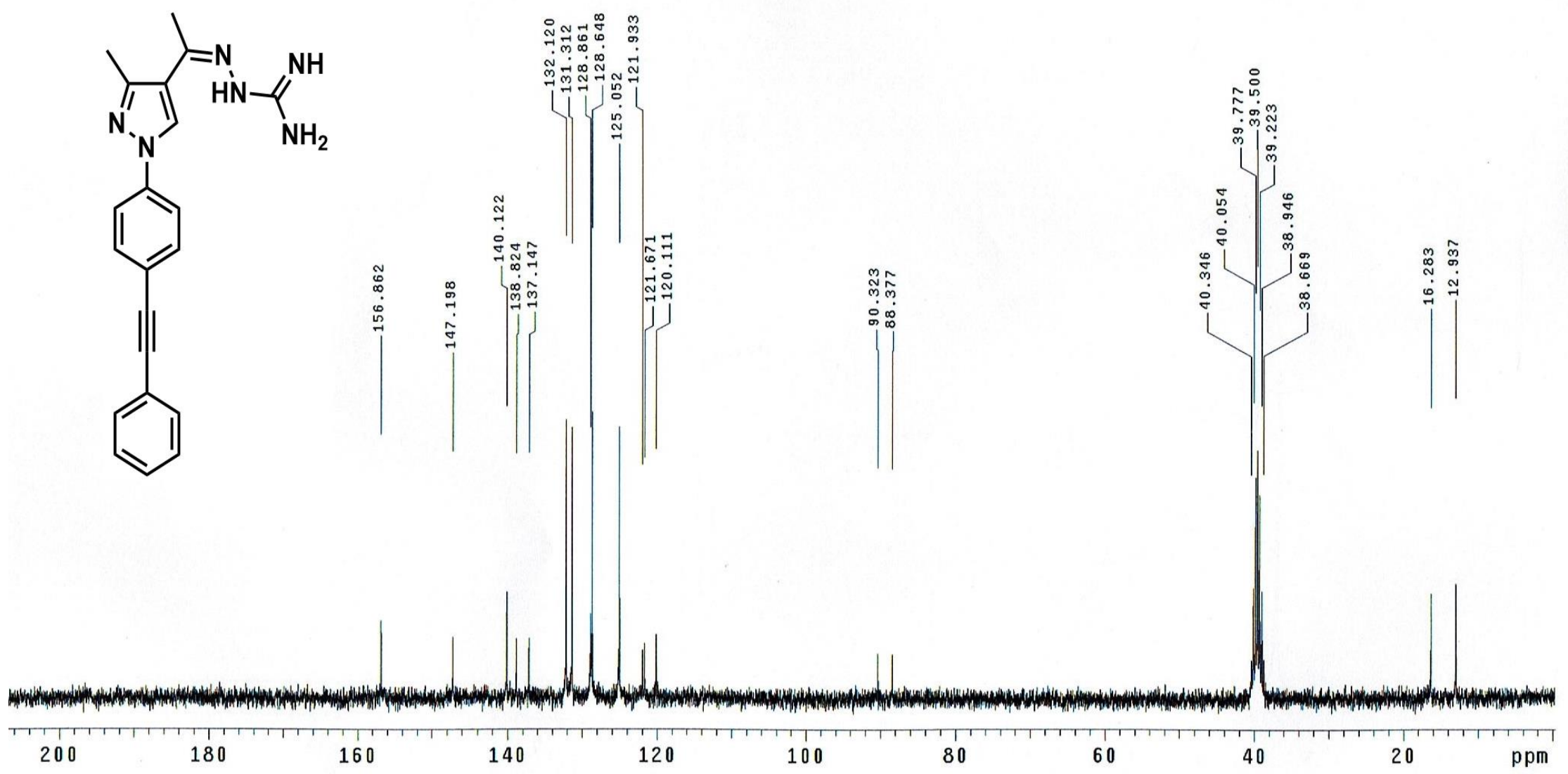

${ }^{13} \mathrm{C}$ NMR of compound 22 


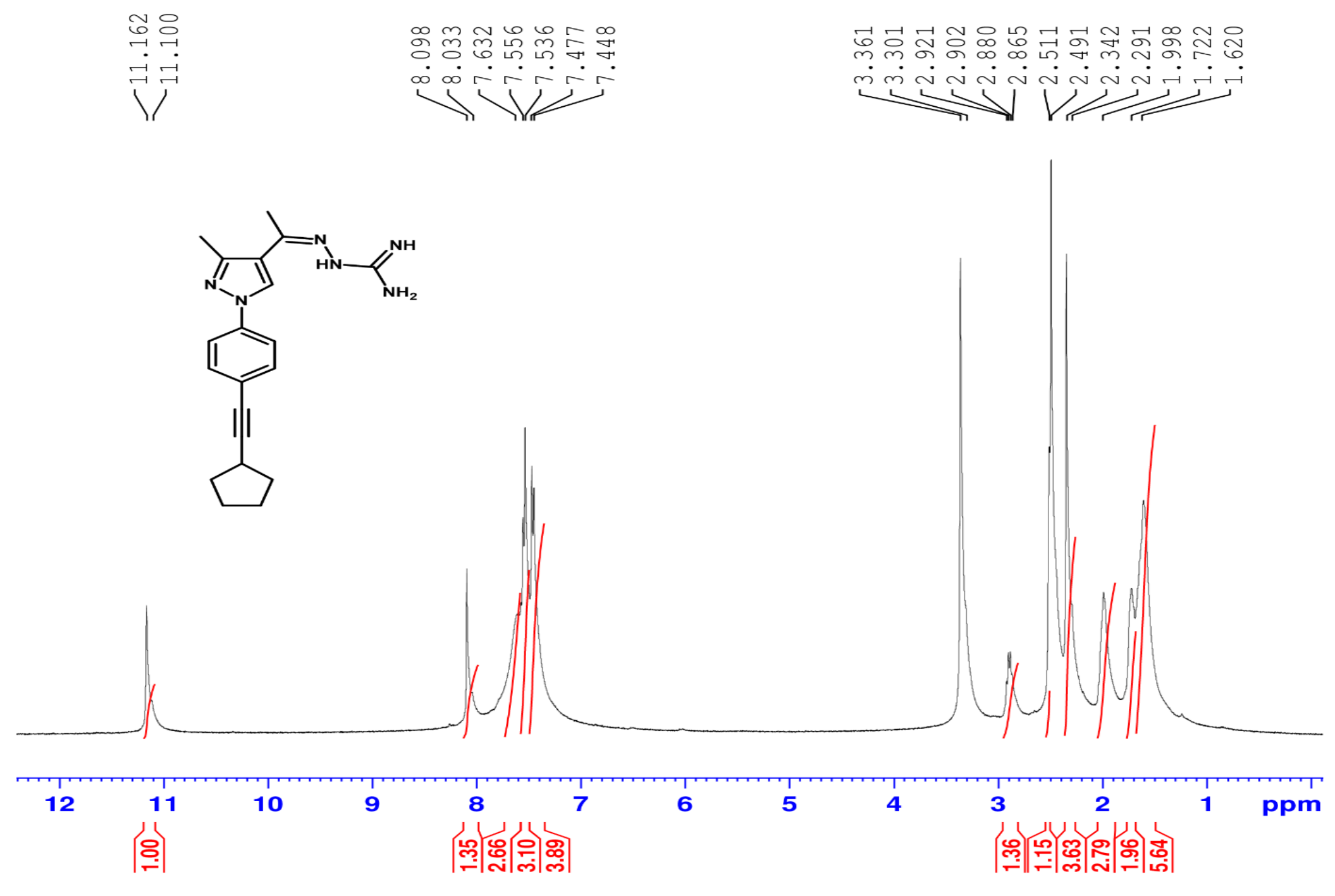

${ }^{1} \mathrm{H}$ NMR of compound 23 


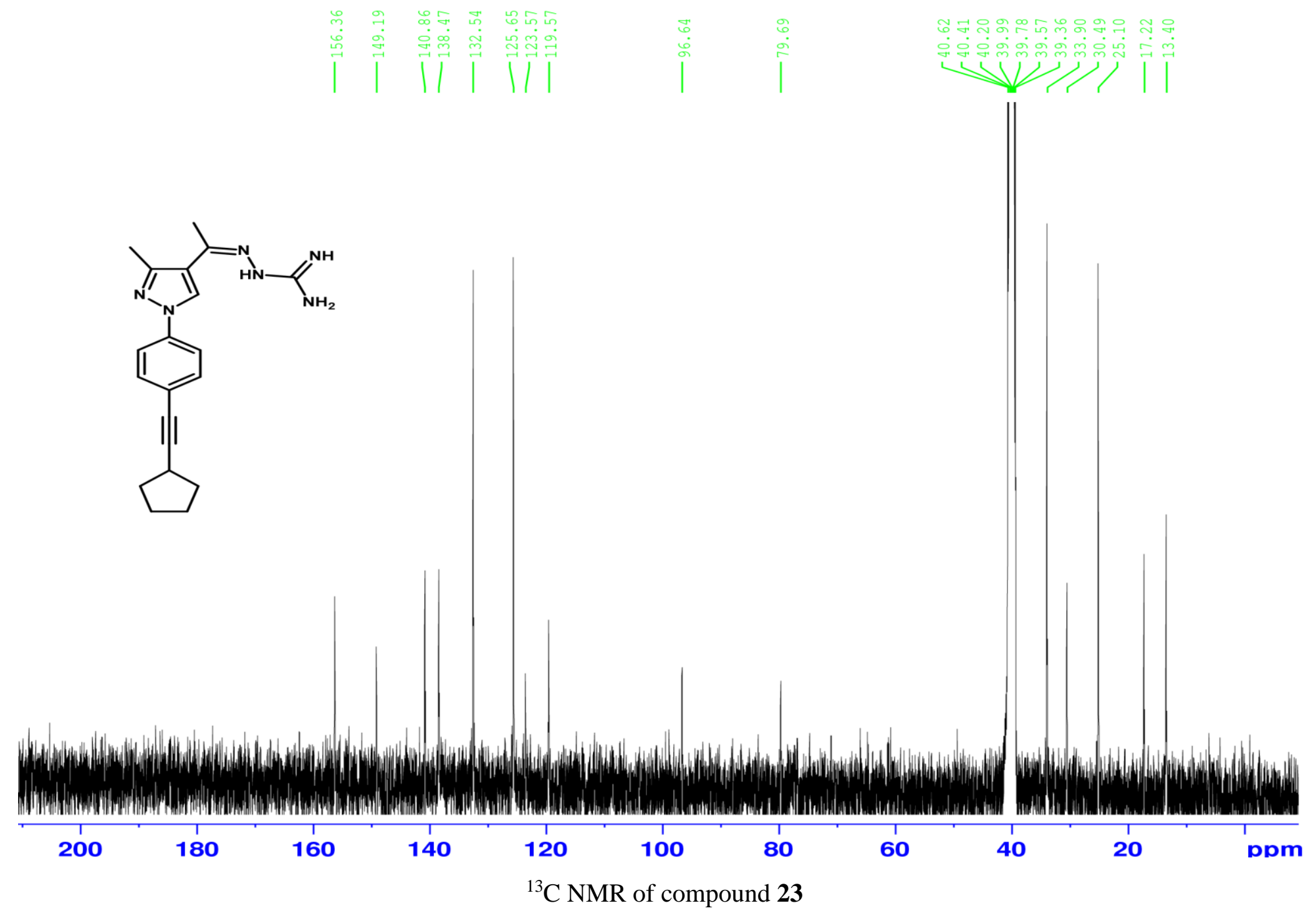




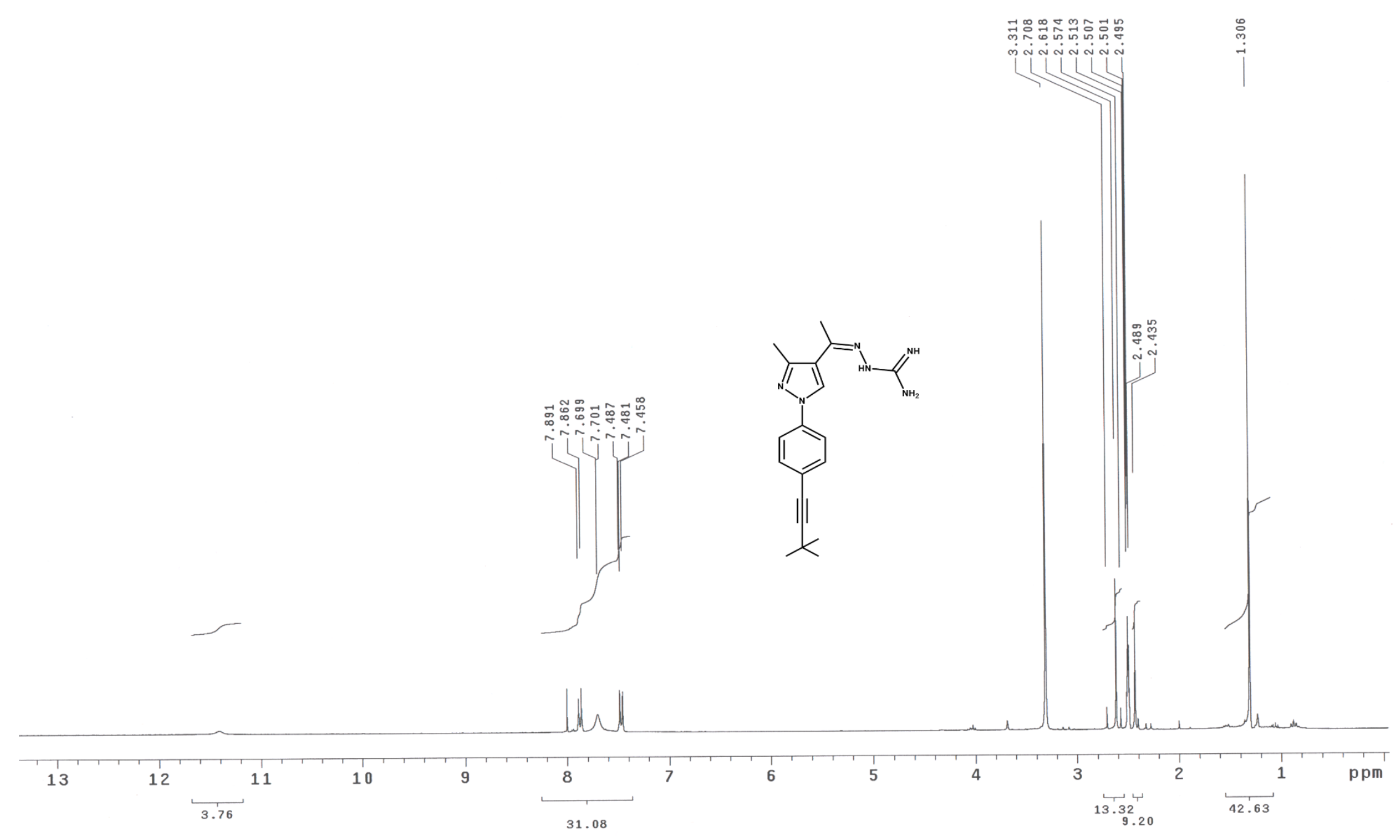

${ }^{1} \mathrm{H}$ NMR of compound 24 


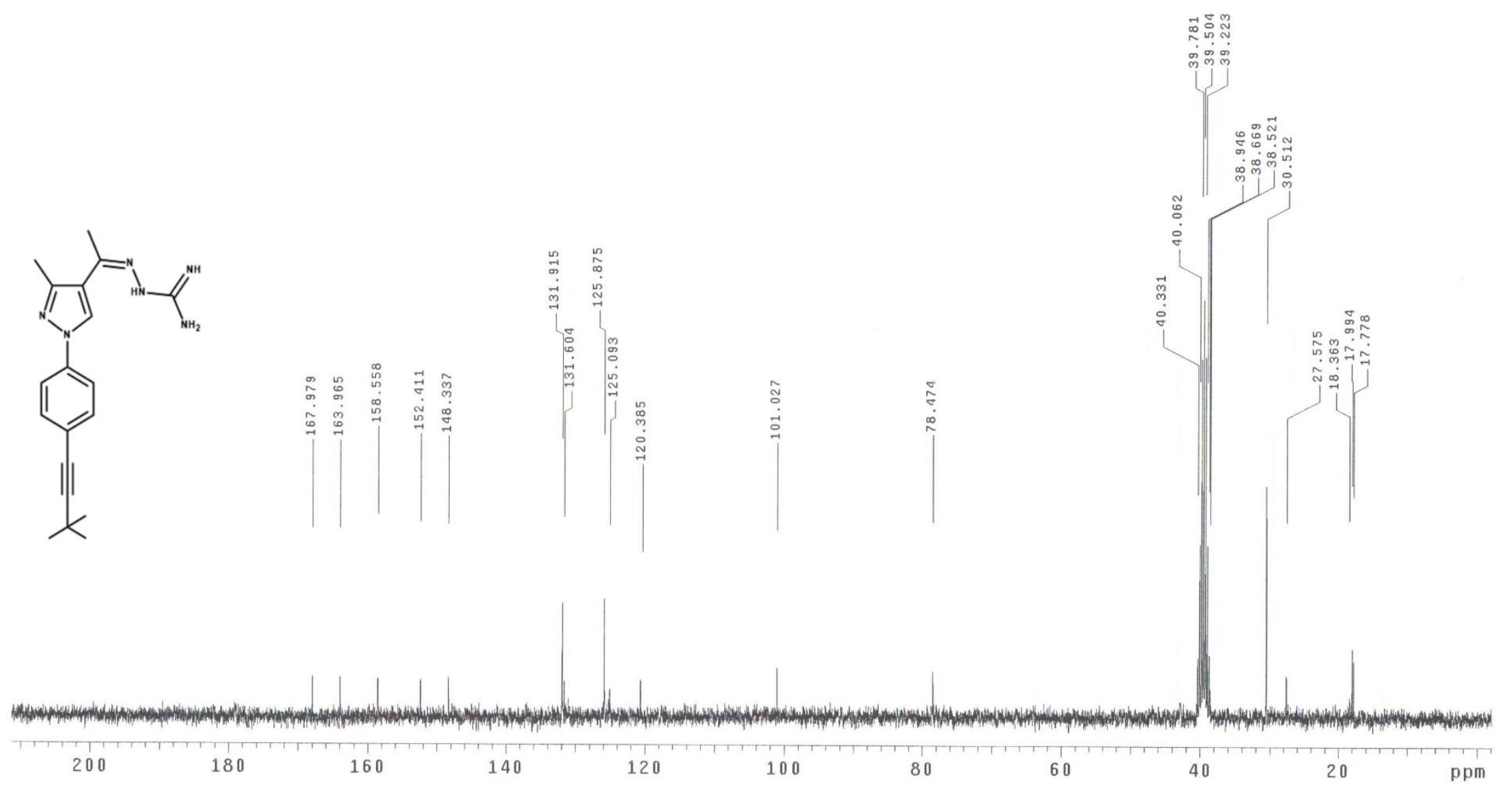

${ }^{13} \mathrm{C}$ NMR of compound 24 


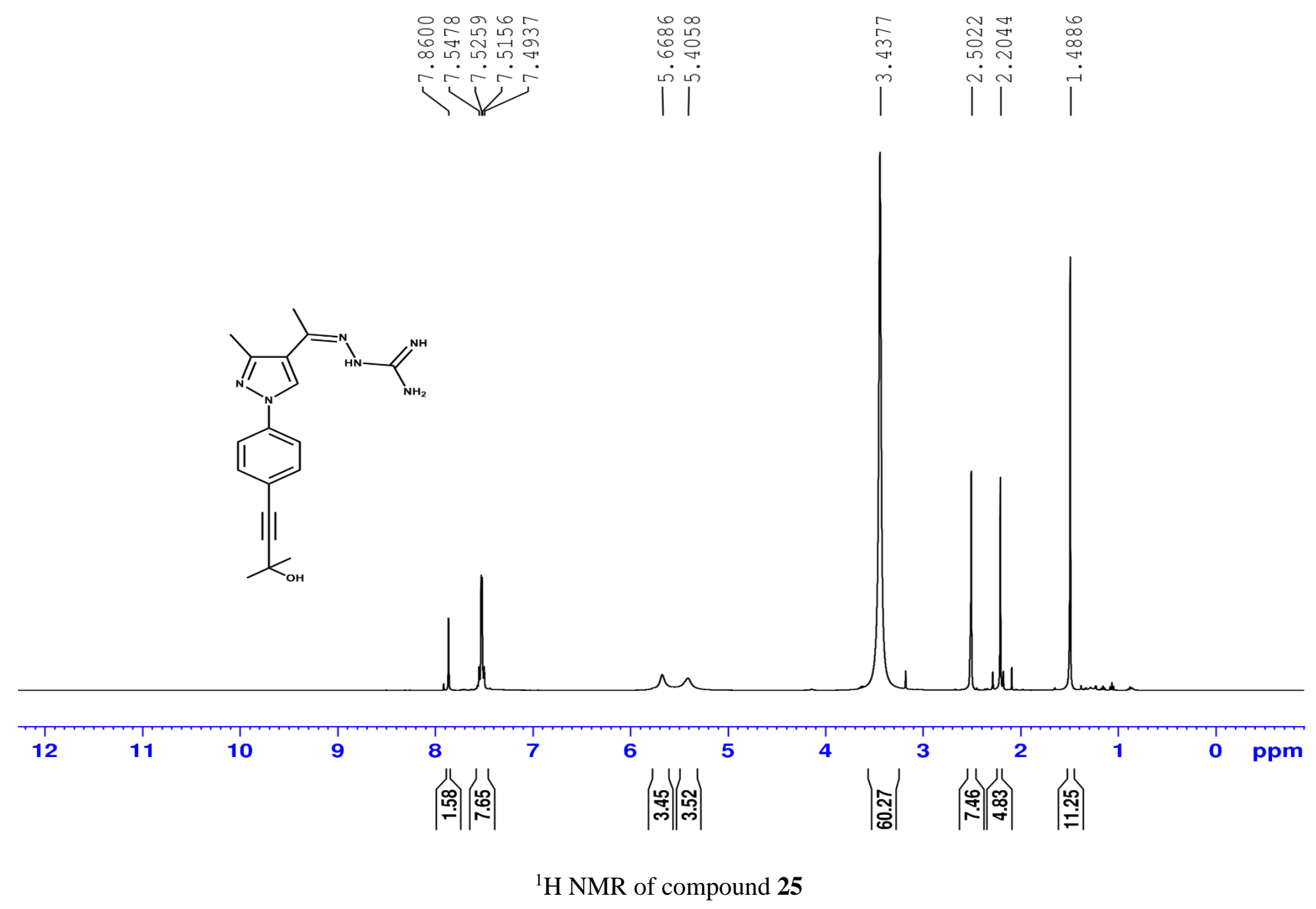




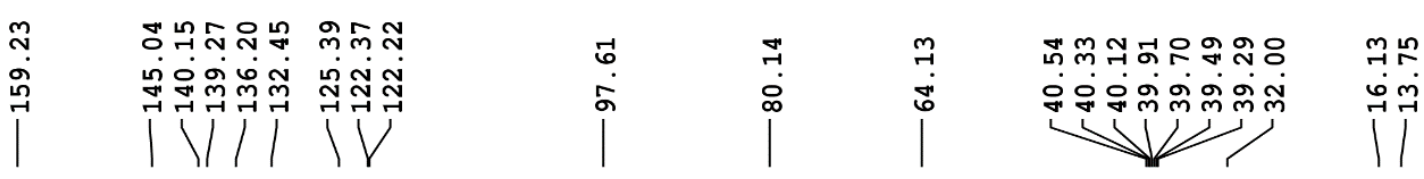
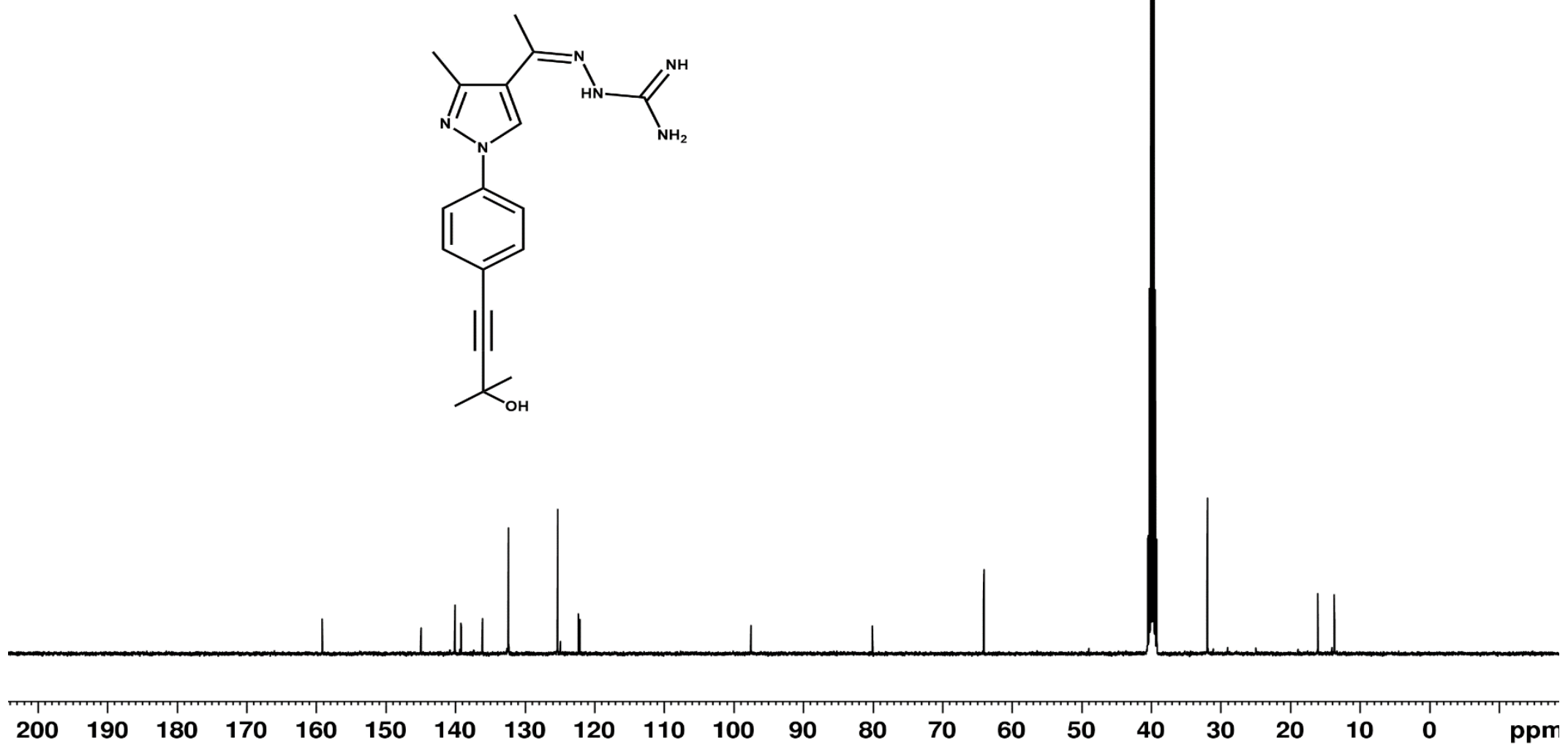

${ }^{13} \mathrm{C}$ NMR of compound 25 


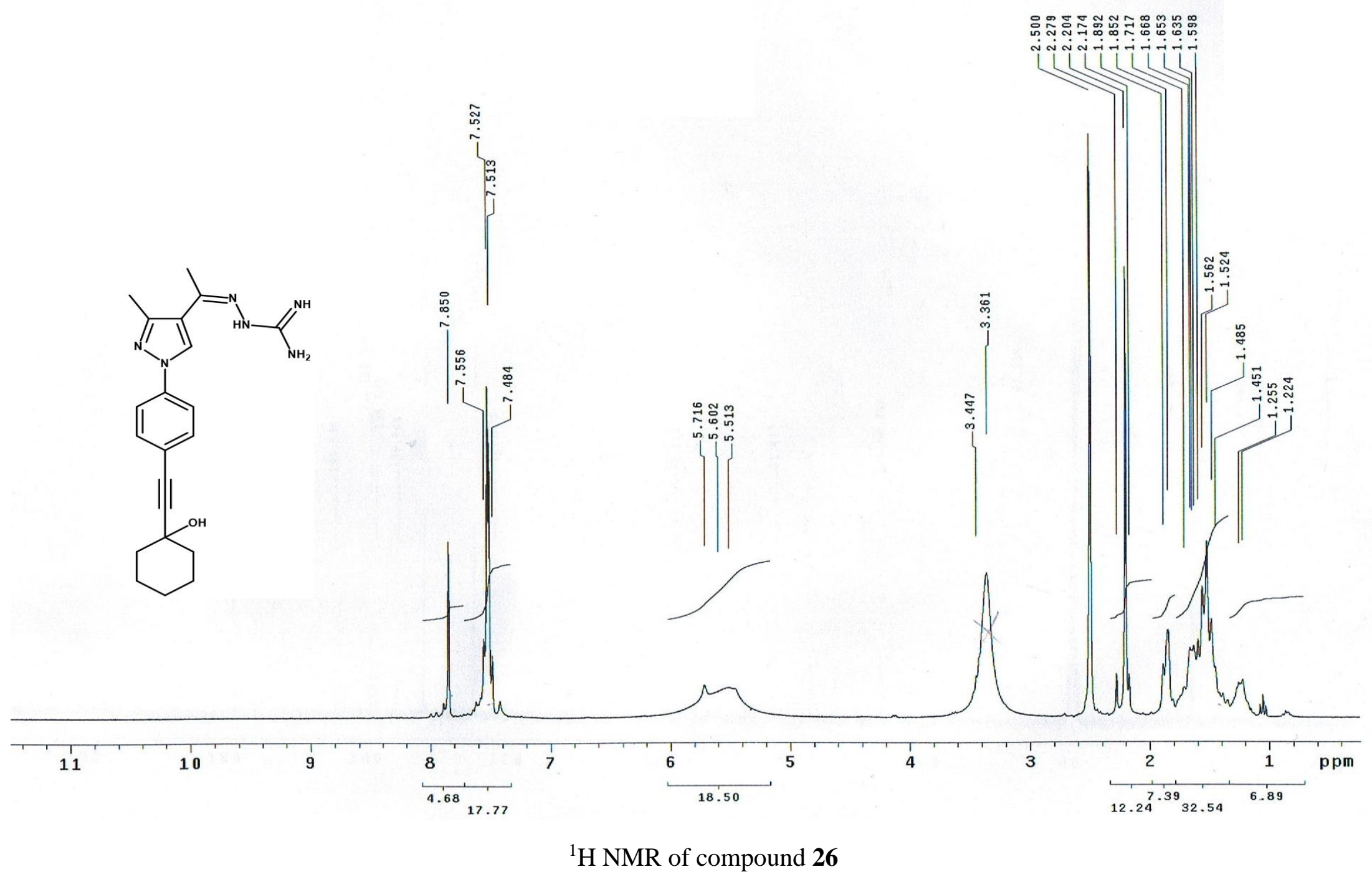




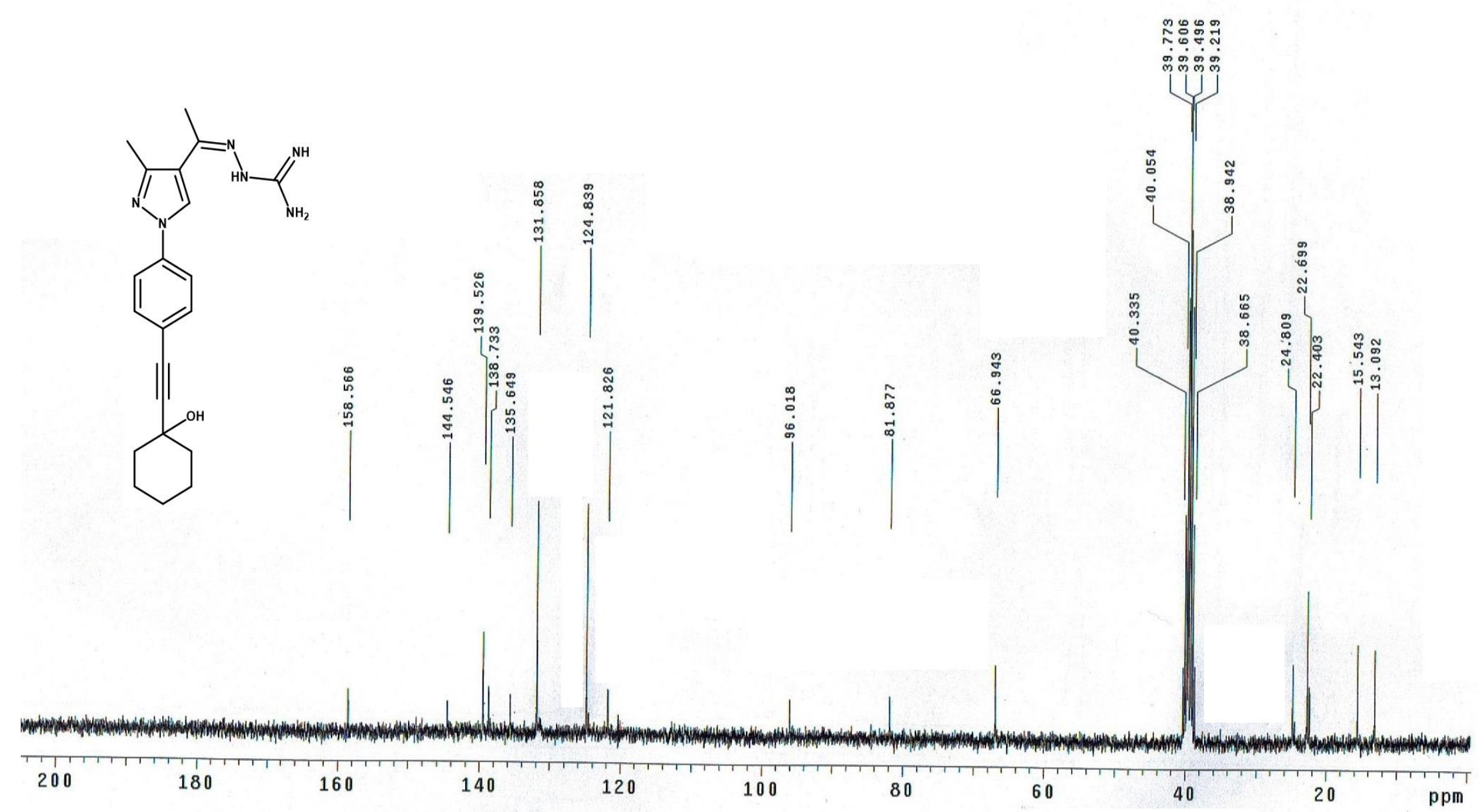

${ }^{13} \mathrm{C}$ NMR of compound 26 


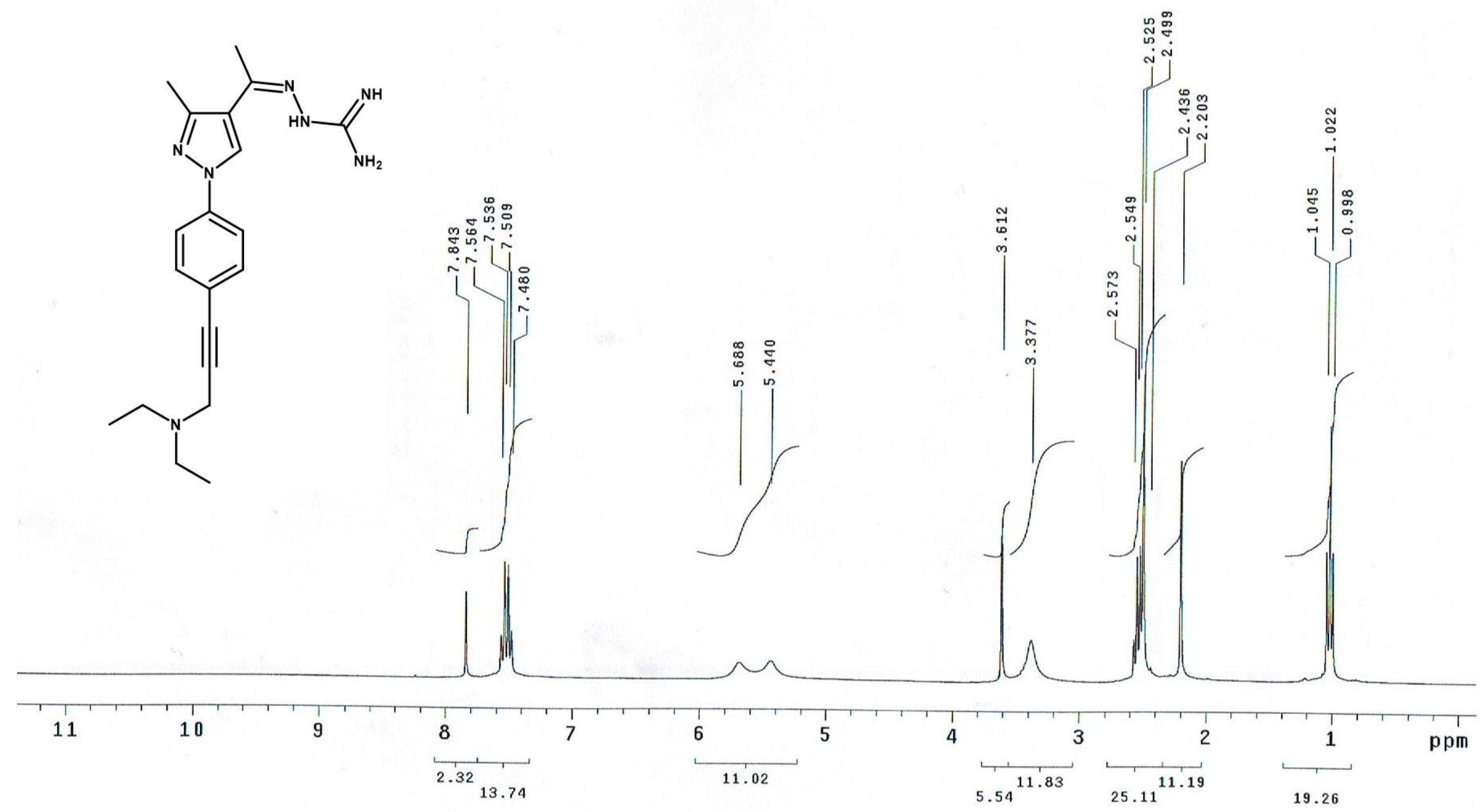

${ }^{1} \mathrm{H}$ NMR of compound 27 

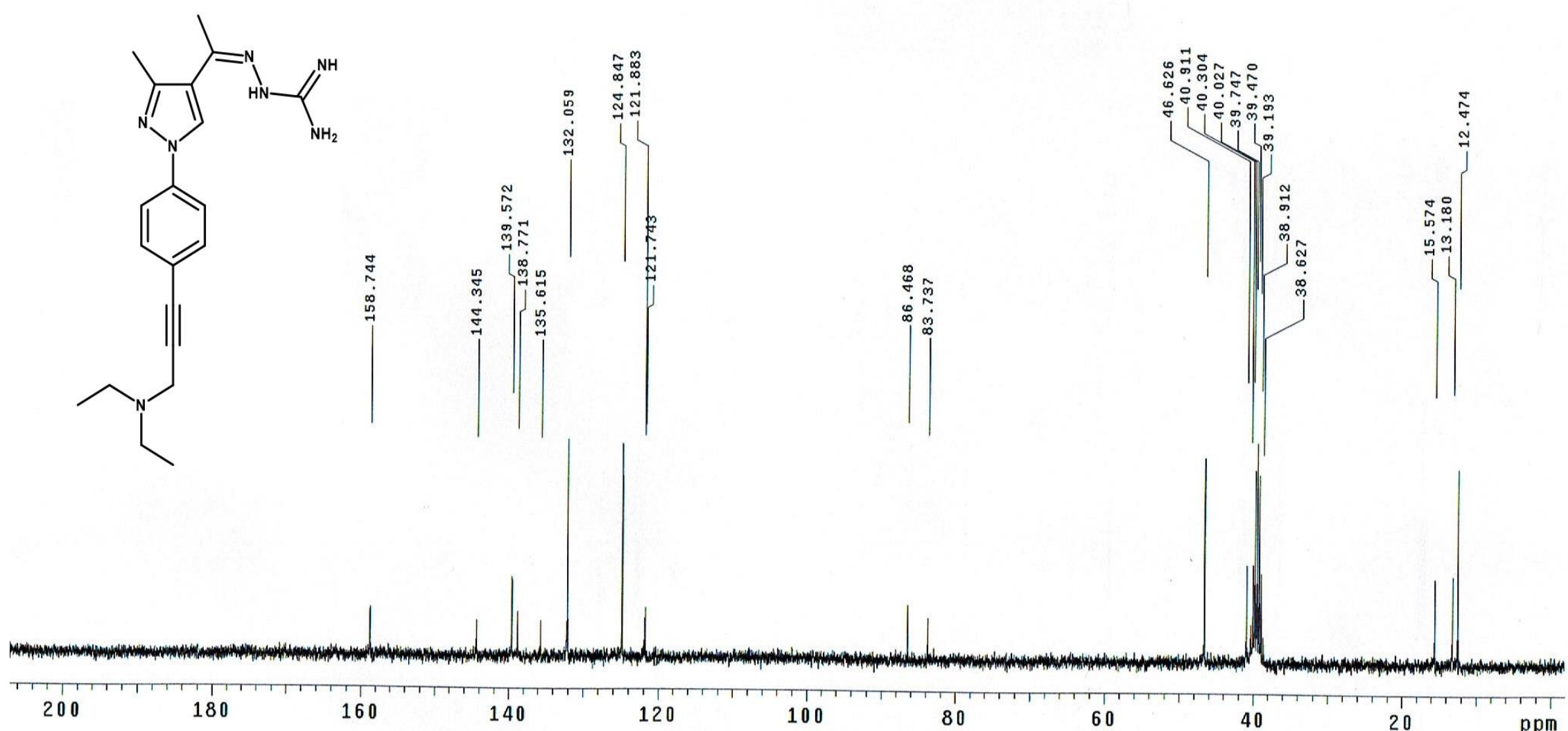

${ }^{13} \mathrm{C}$ NMR of compound 27 

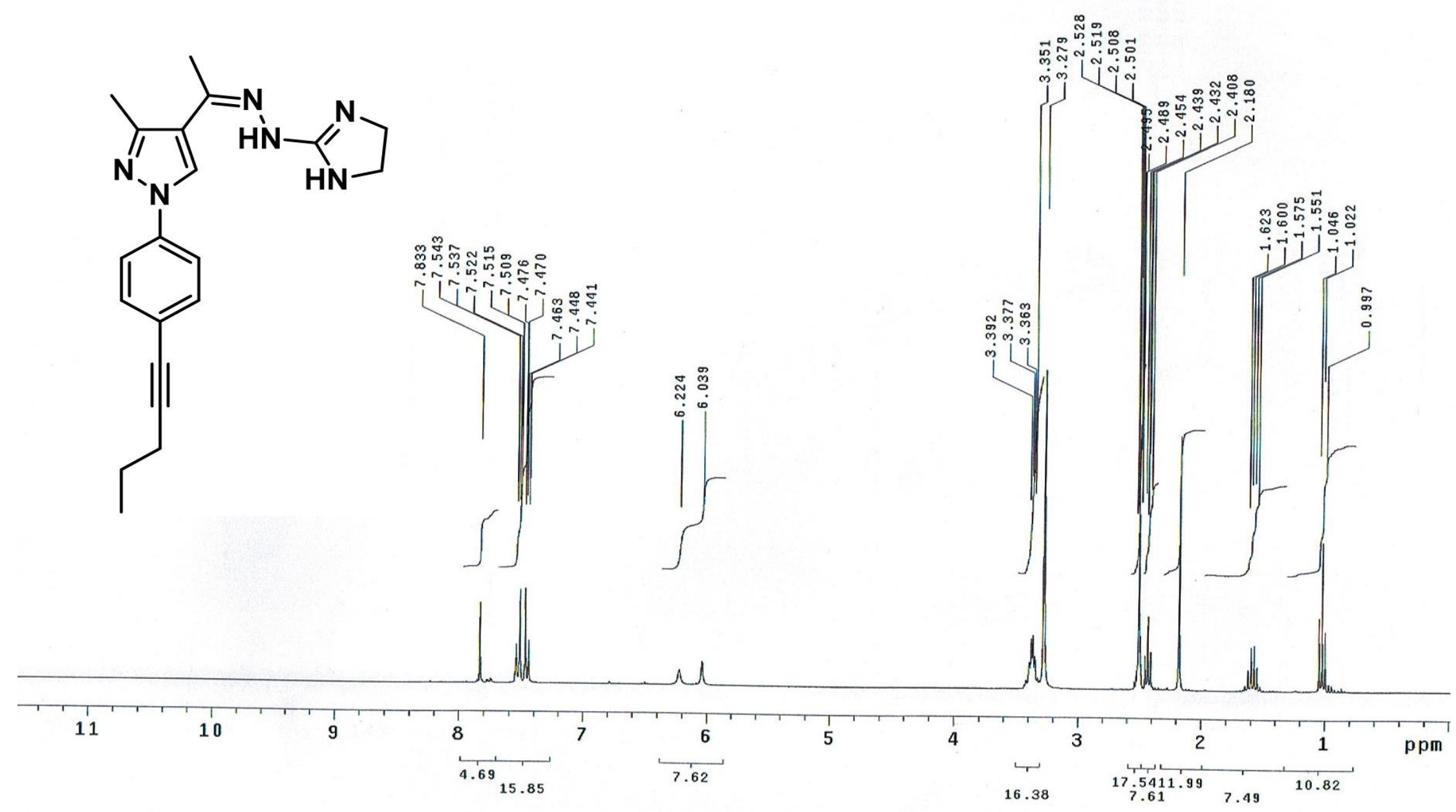

${ }^{1} \mathrm{H}$ NMR of compound 28 


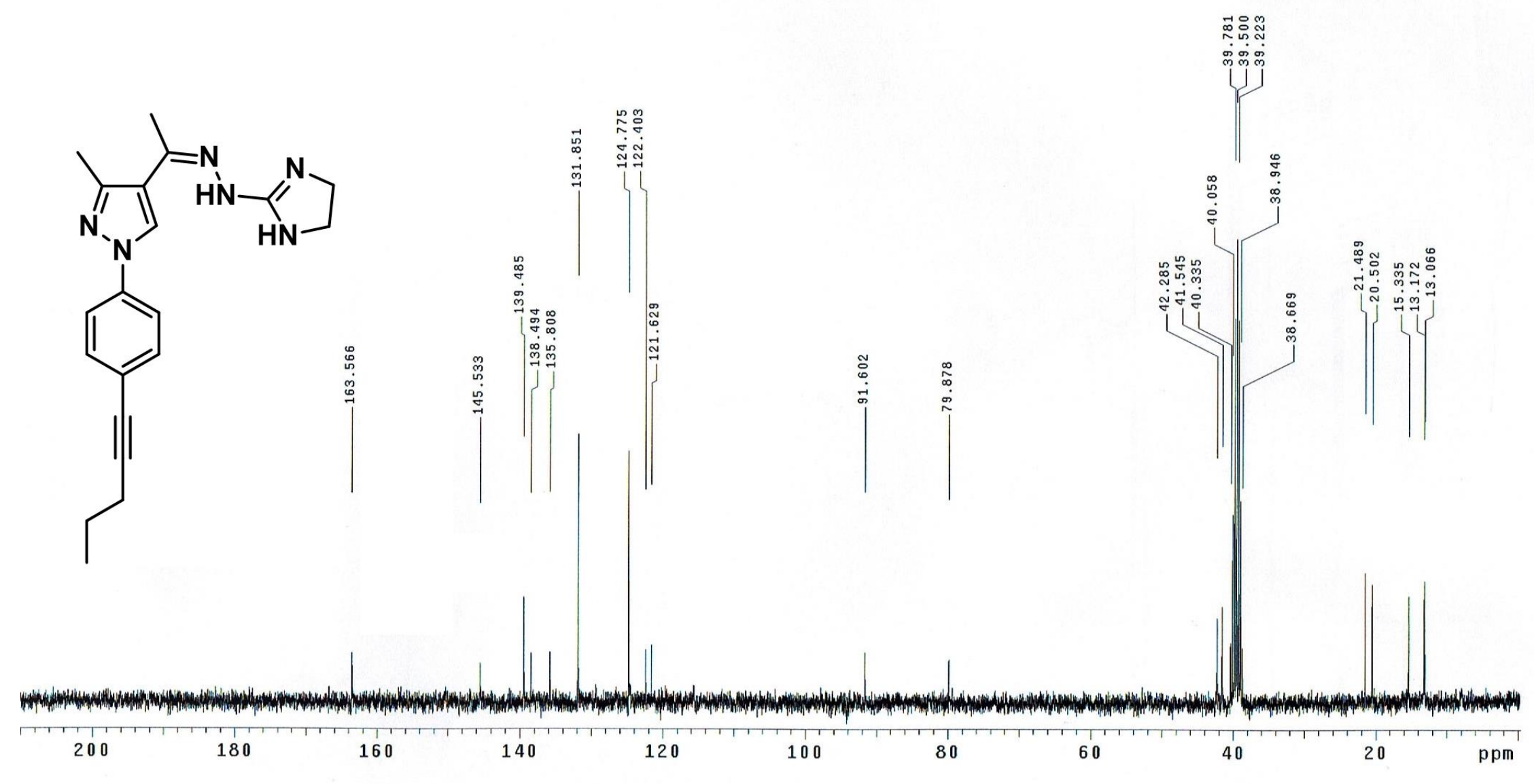

${ }^{13} \mathrm{C}$ NMR of compound 28 


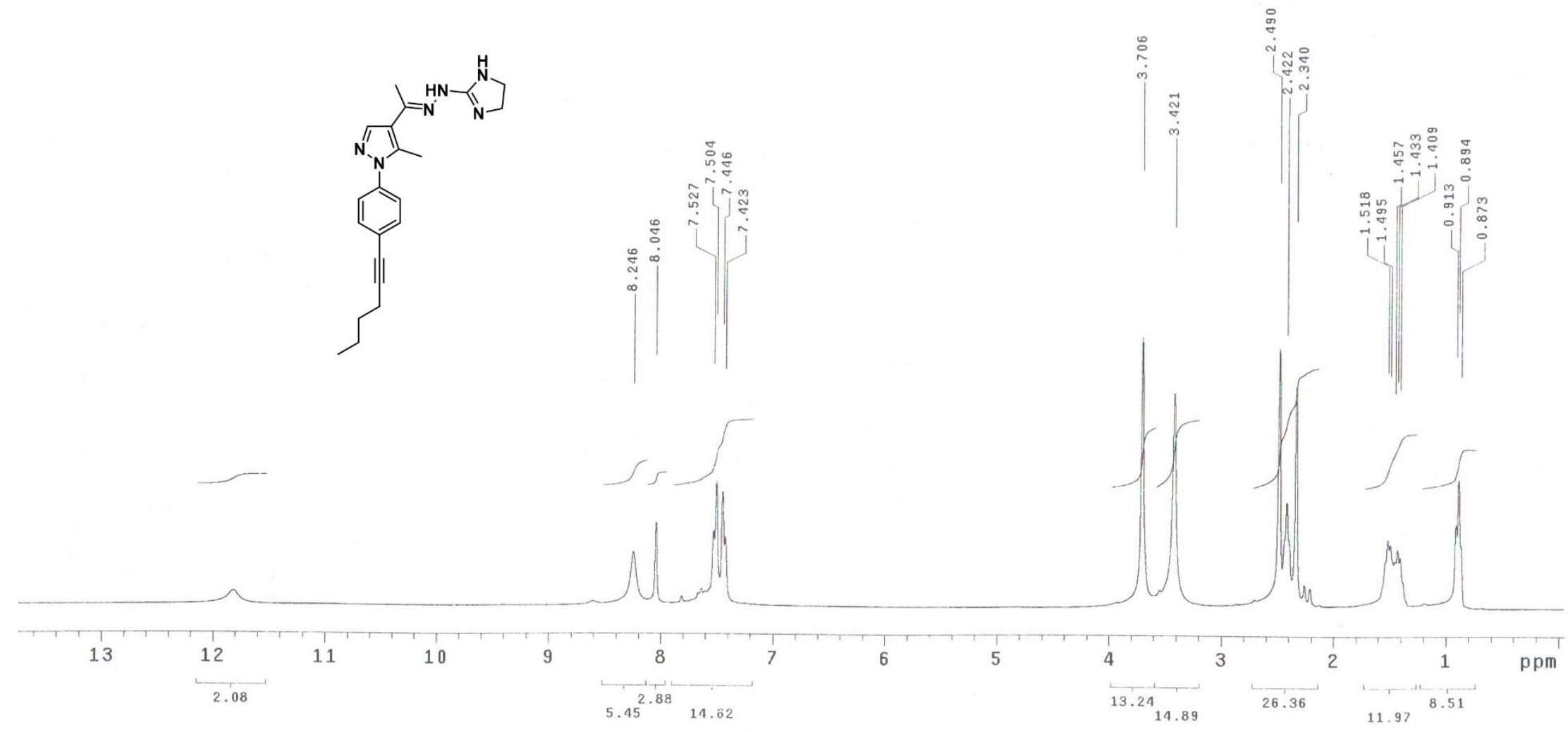

${ }^{1} \mathrm{H}$ NMR of compound 29 


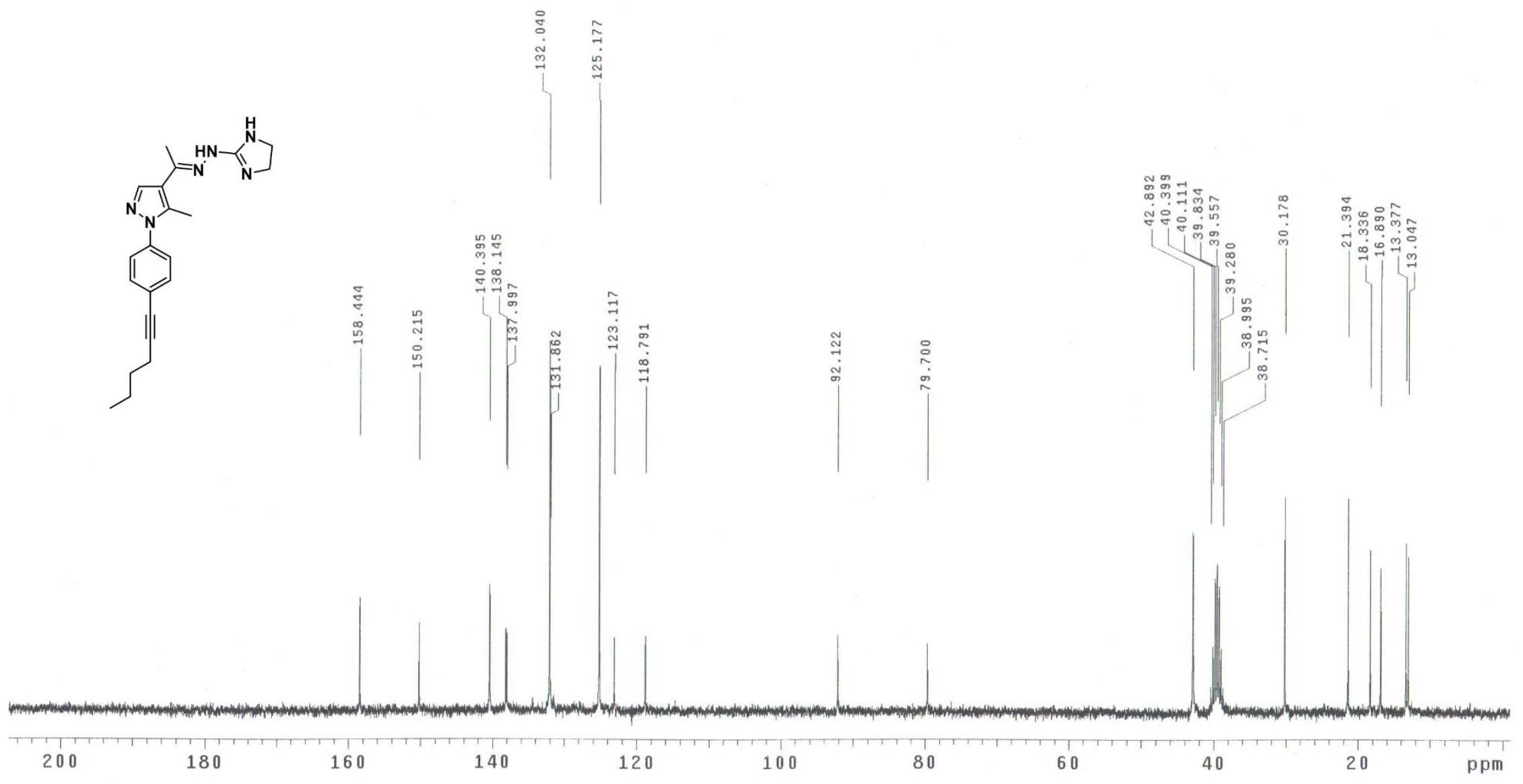

${ }^{13} \mathrm{C}$ NMR of compound 29 

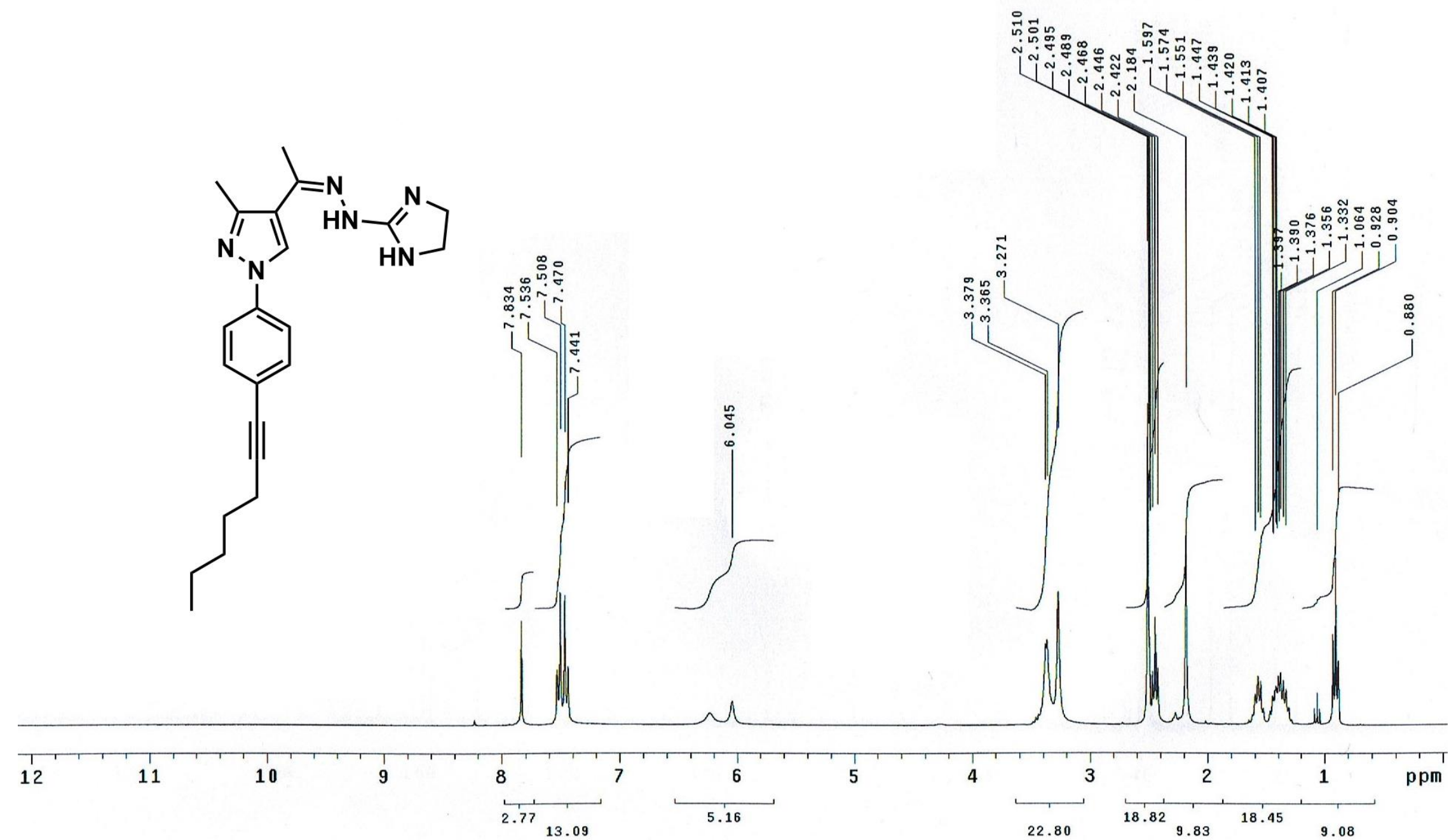

${ }^{1} \mathrm{H}$ NMR of compound 30 


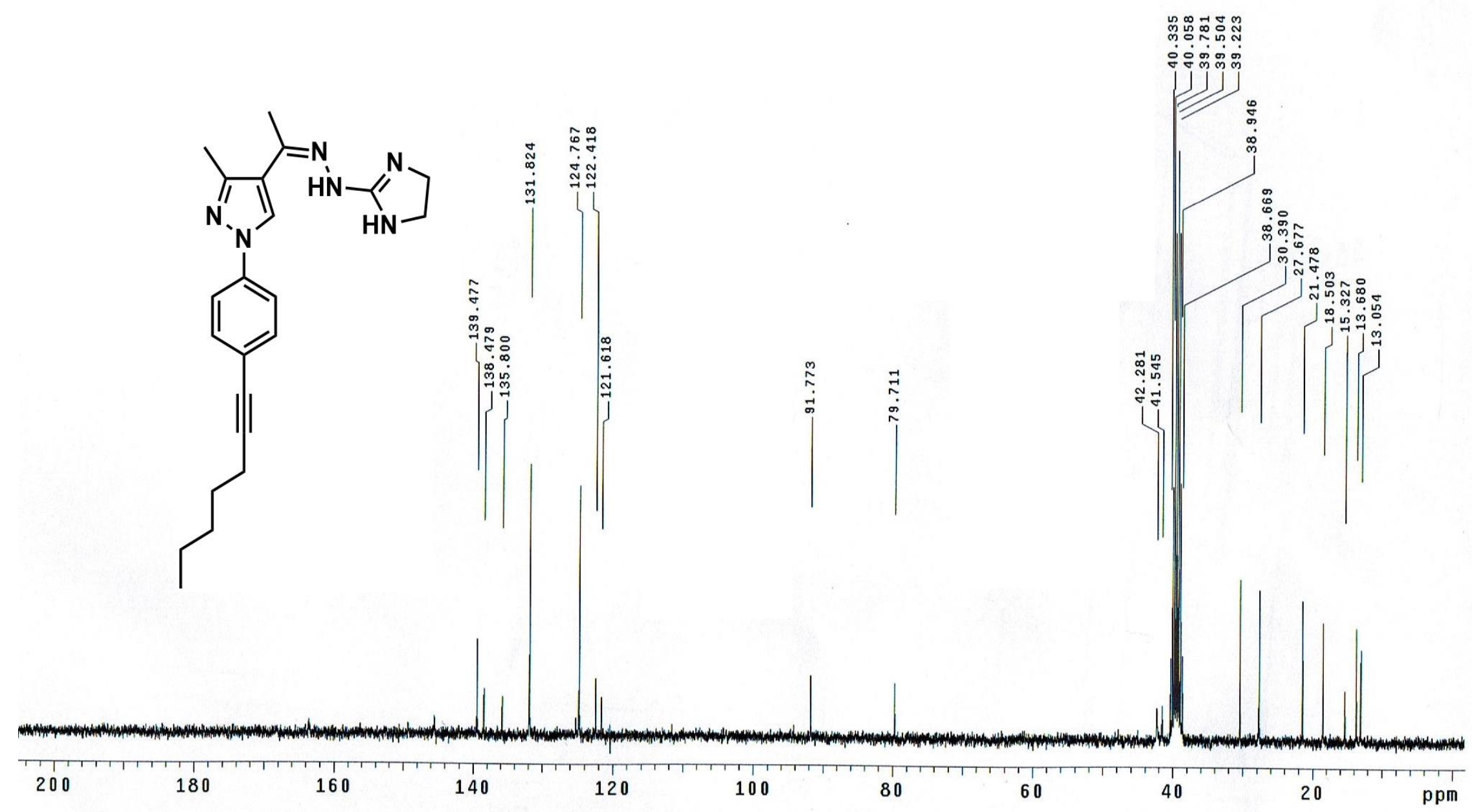

${ }^{13} \mathrm{C}$ NMR of compound 30 


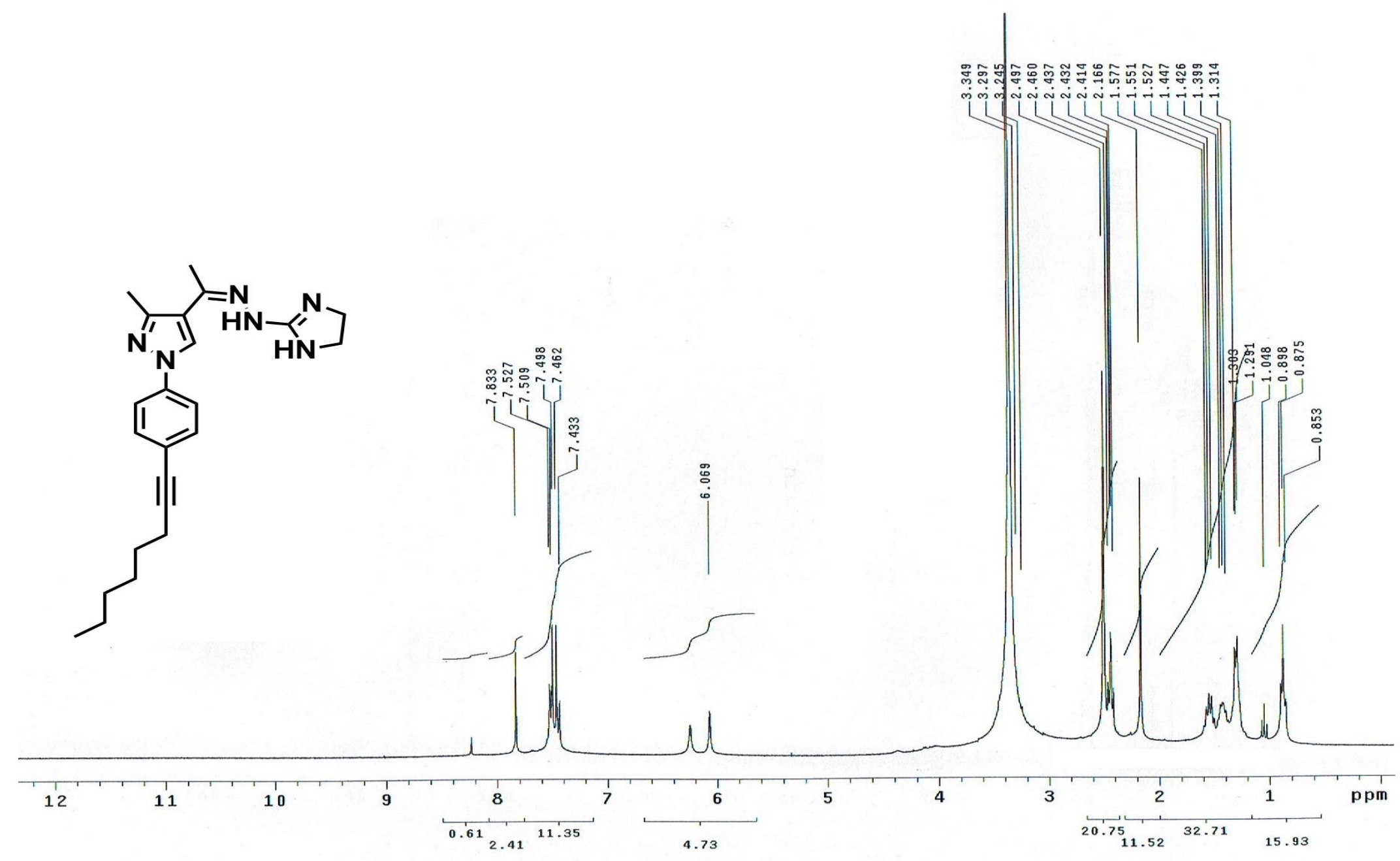

${ }^{1} \mathrm{H}$ NMR of compound 31 


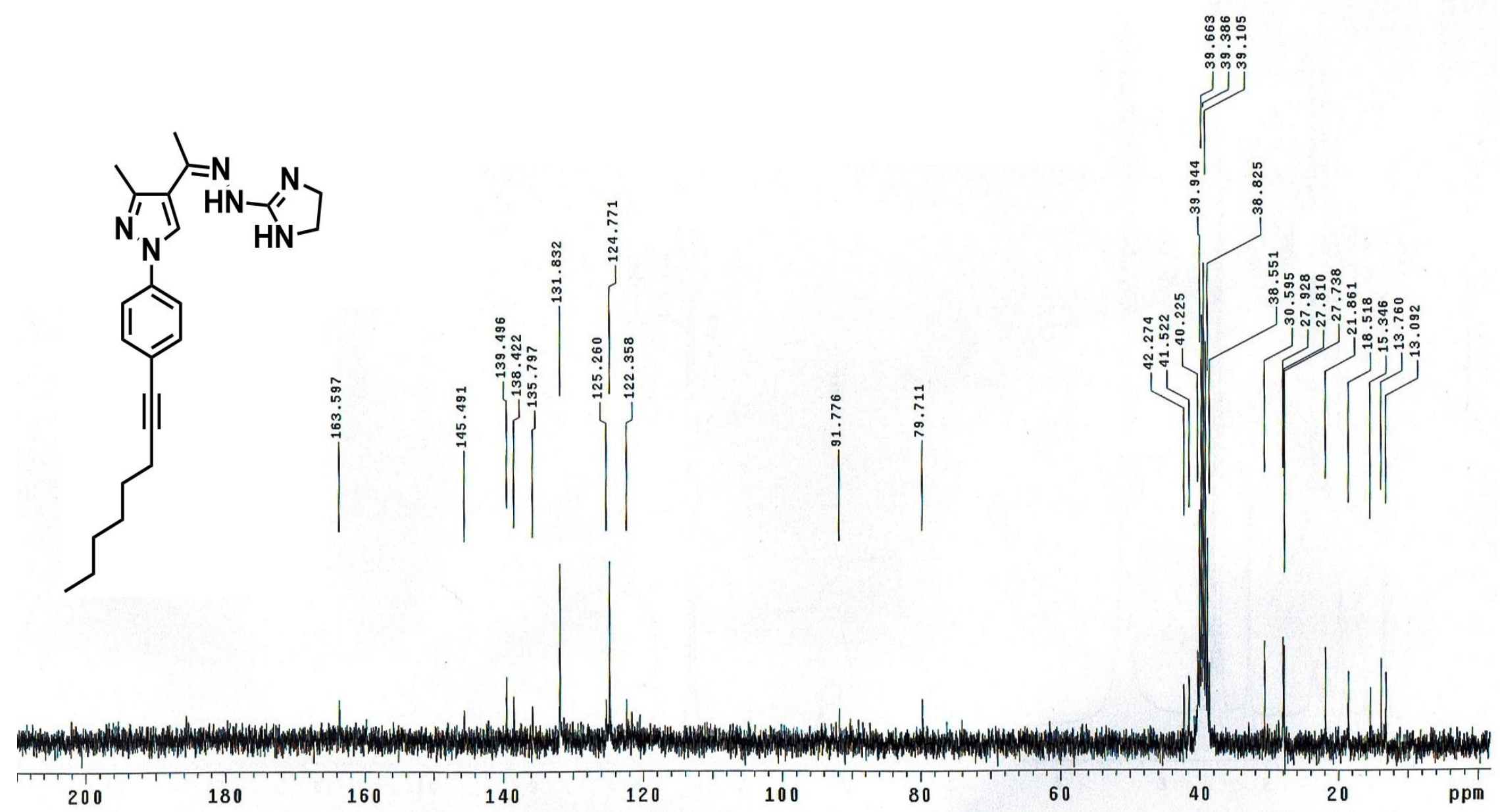

${ }^{13} \mathrm{C}$ NMR of compound 31 


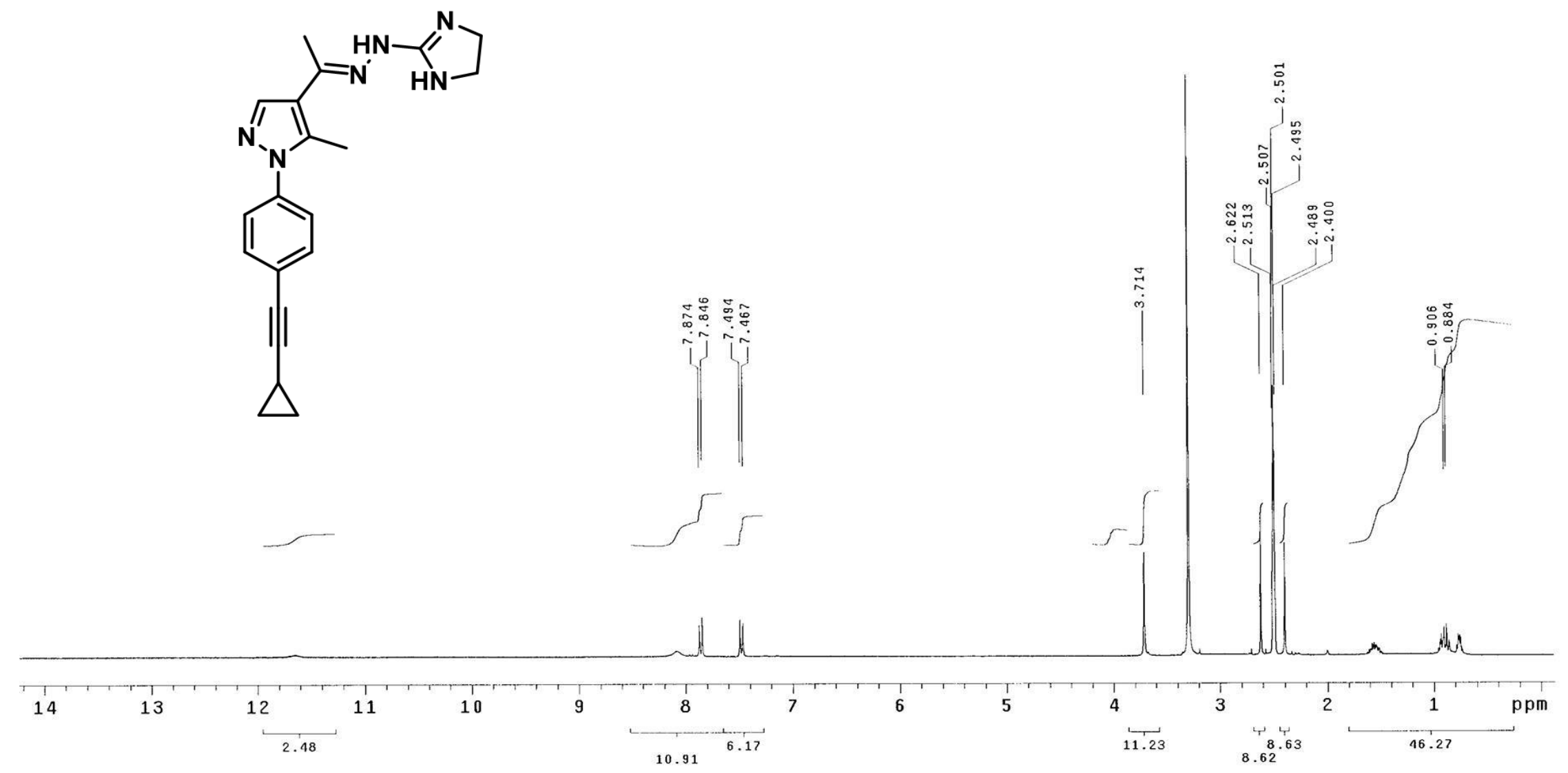

${ }^{1} \mathrm{H}$ NMR of compound 32 

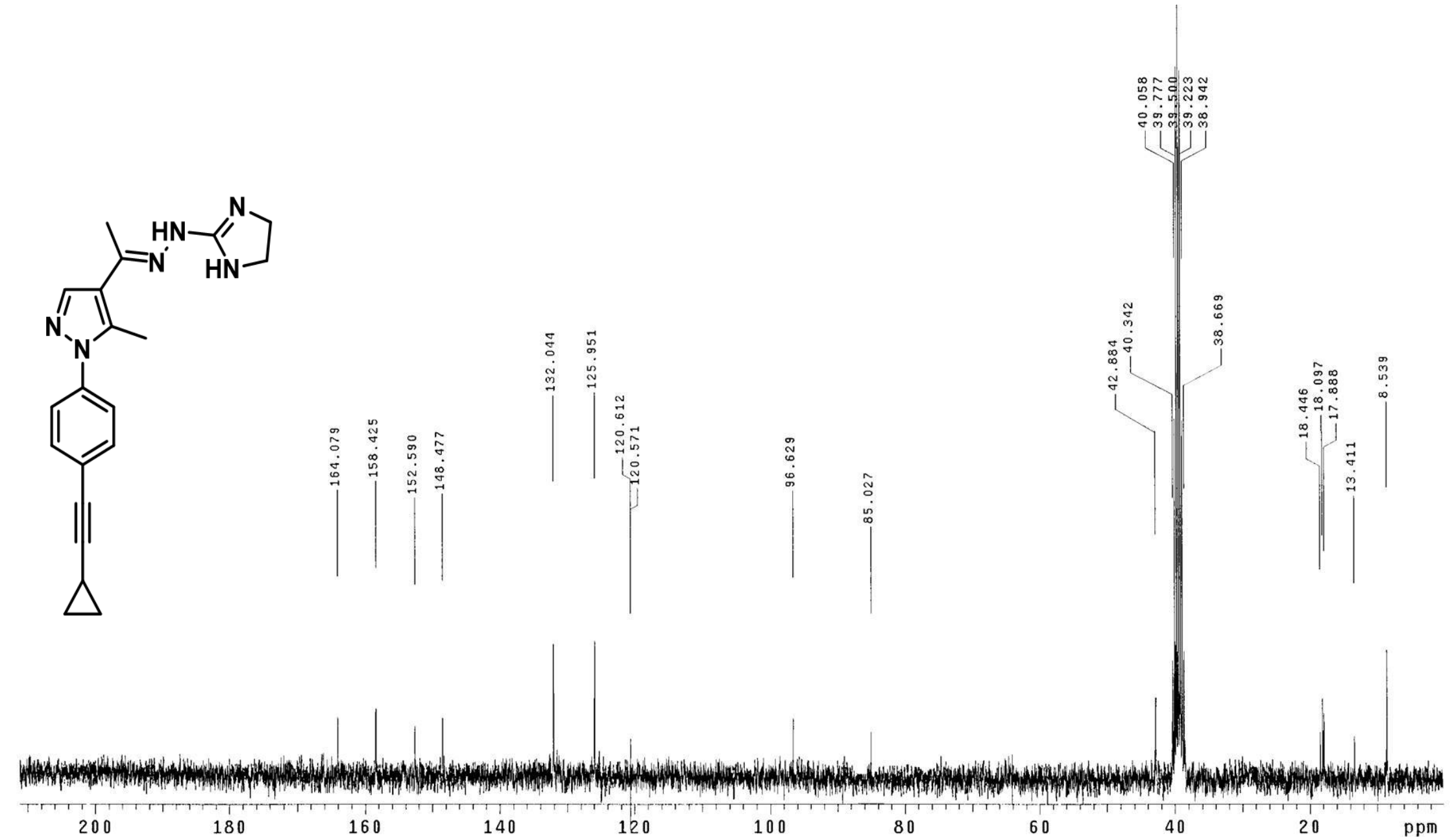

${ }^{13} \mathrm{C}$ NMR of compound 32 


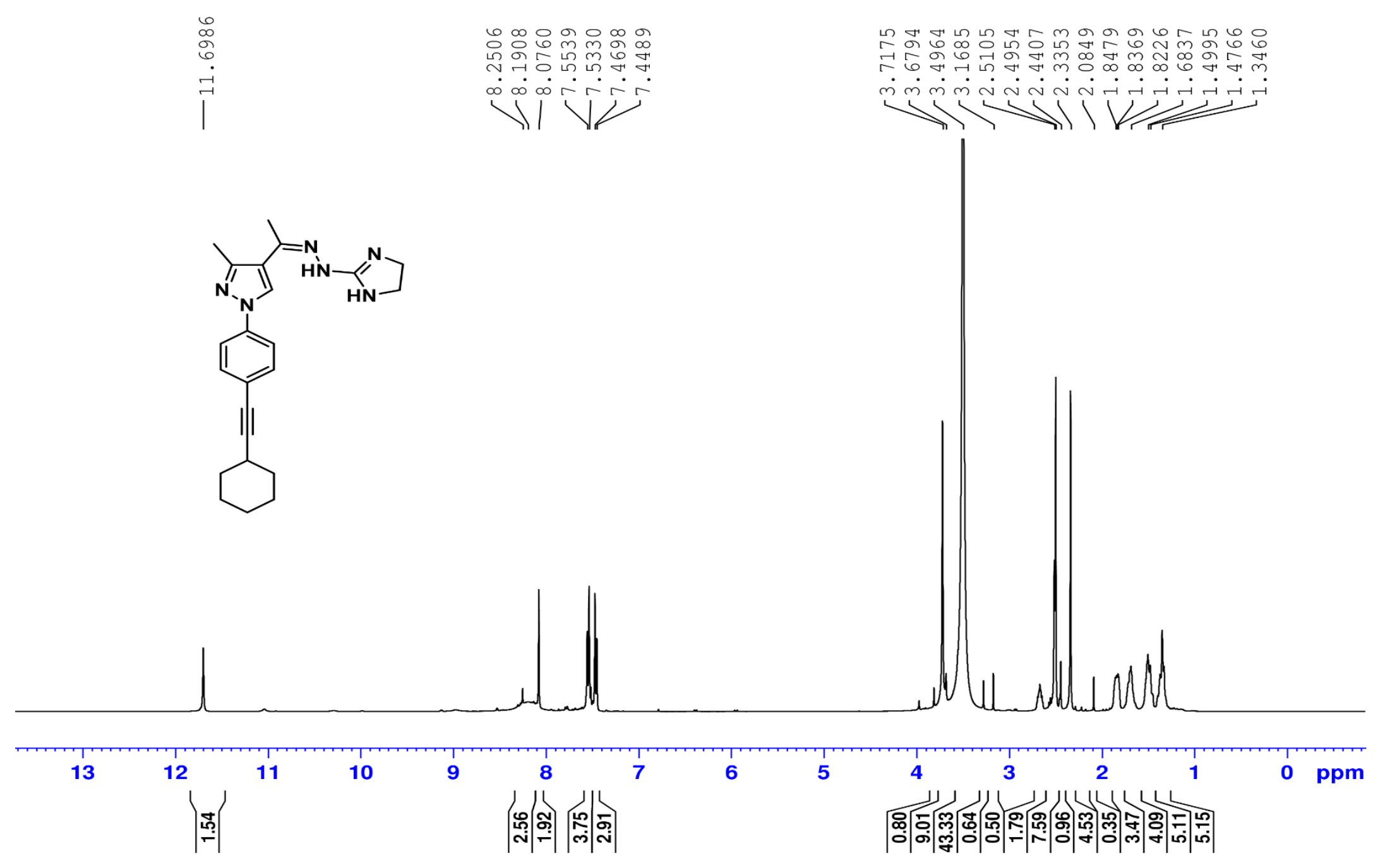

${ }^{1} \mathrm{H}$ NMR of compound $\mathbf{3 3}$ 


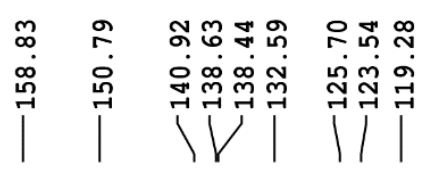

m.

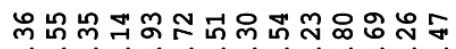

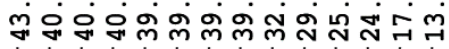
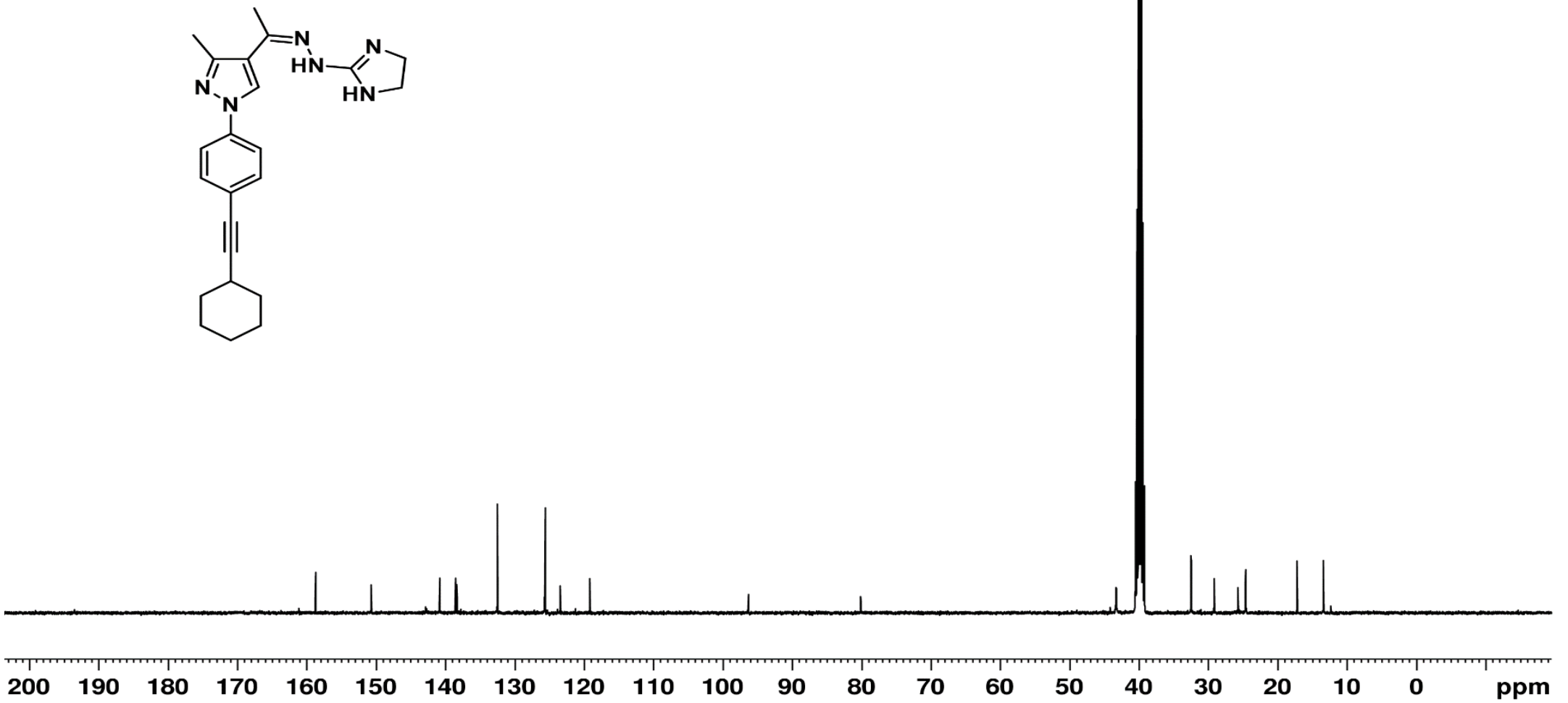

${ }^{13} \mathrm{C}$ NMR of compound $\mathbf{3 3}$ 


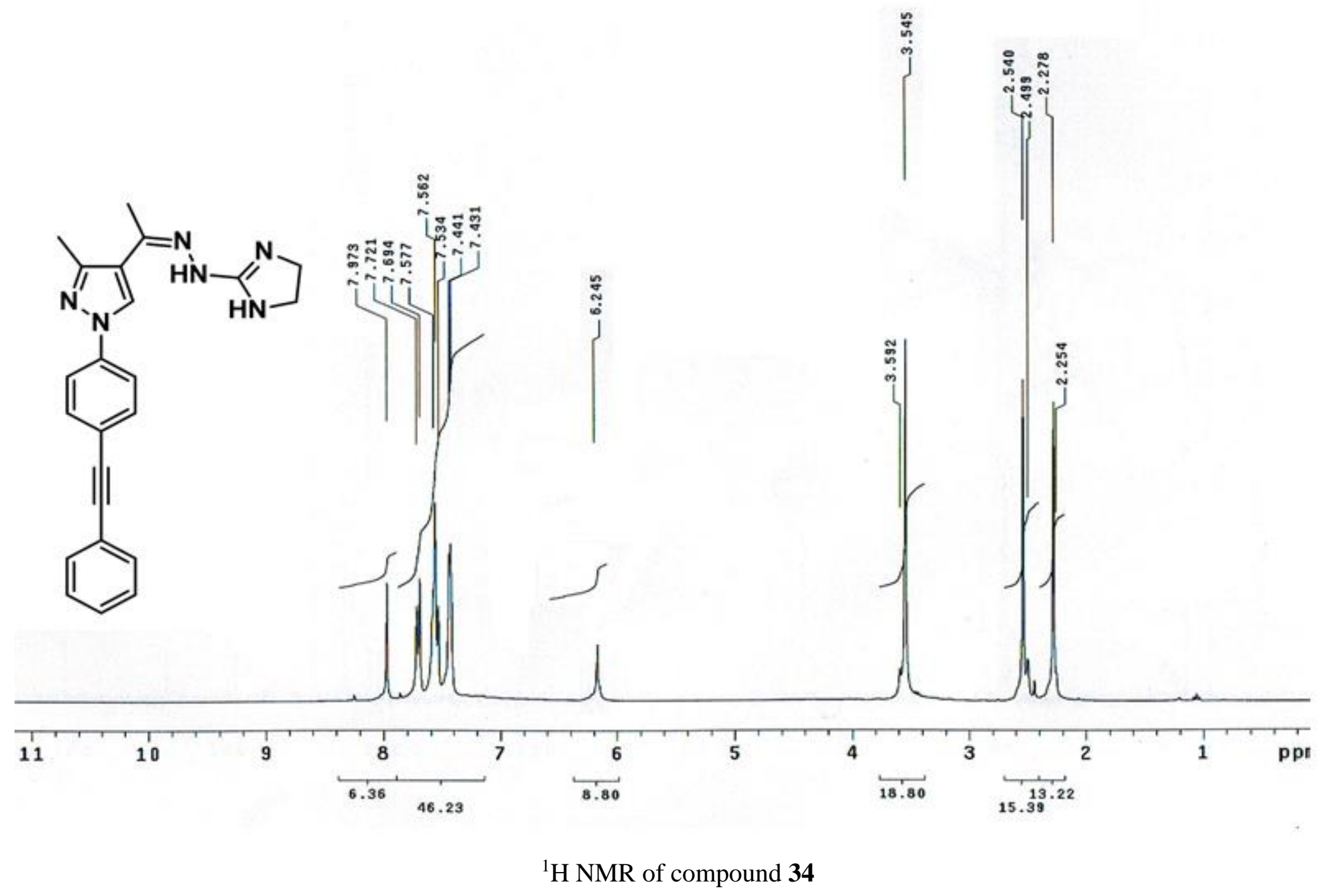




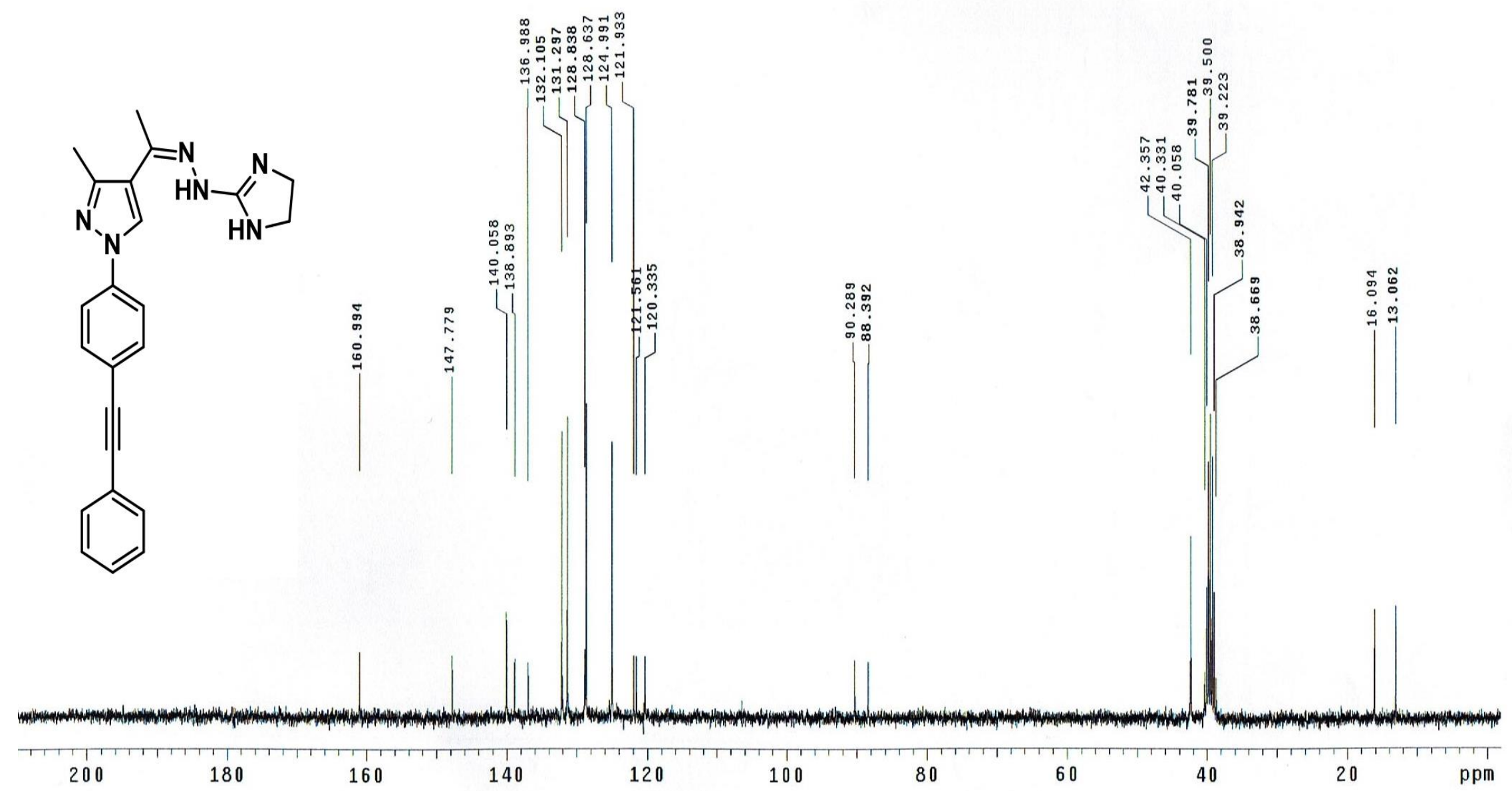

${ }^{13} \mathrm{C}$ NMR of compound 34 


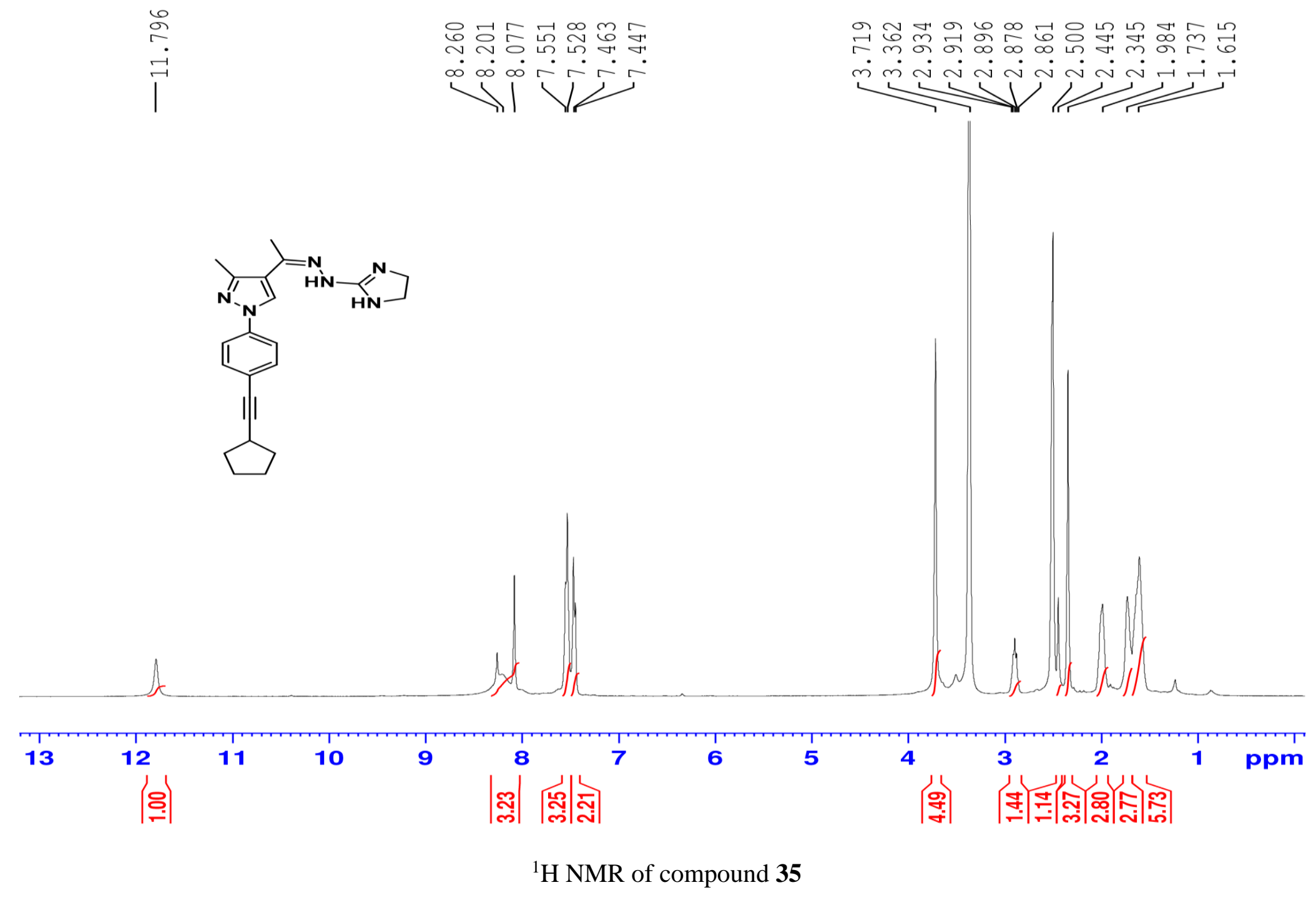




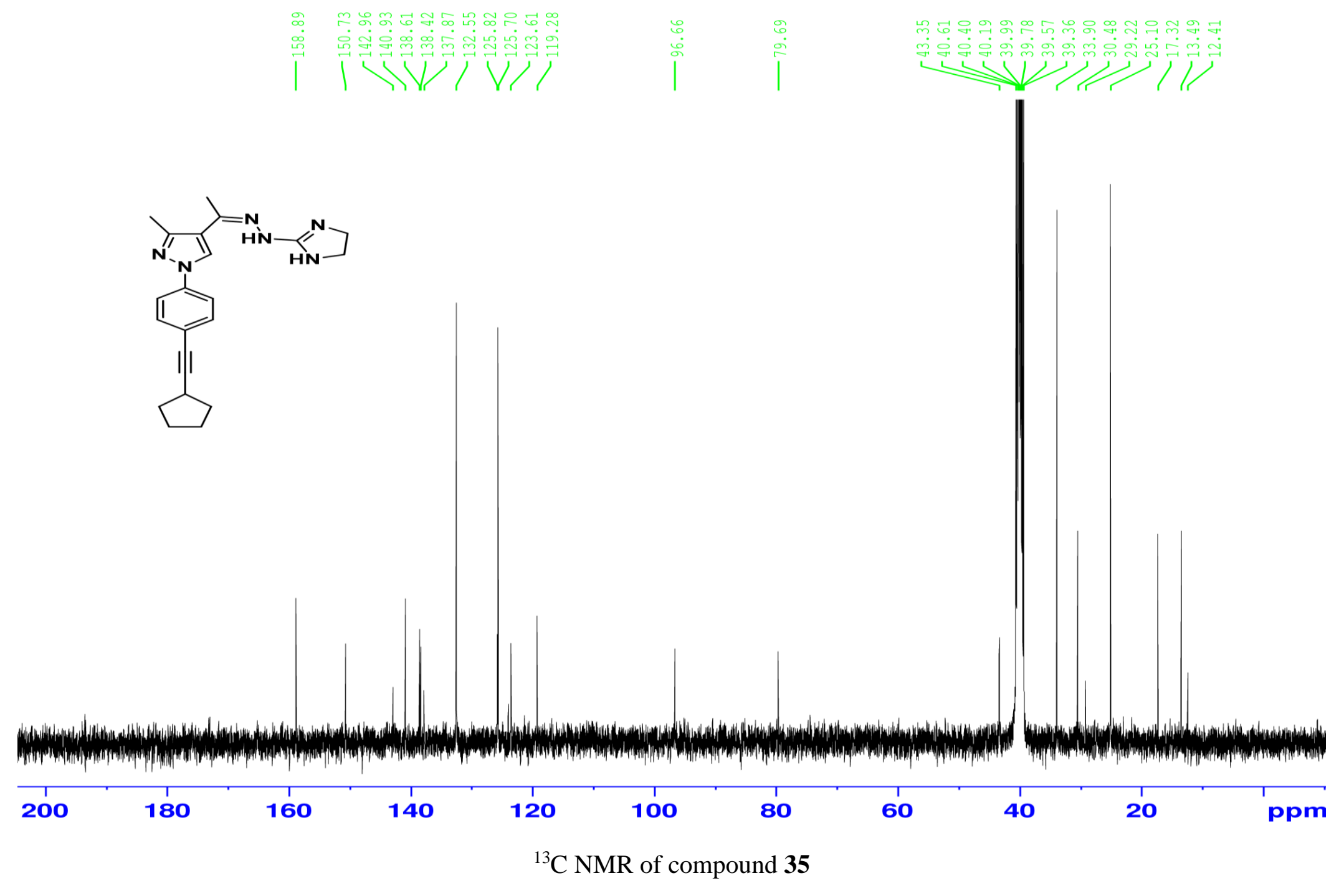




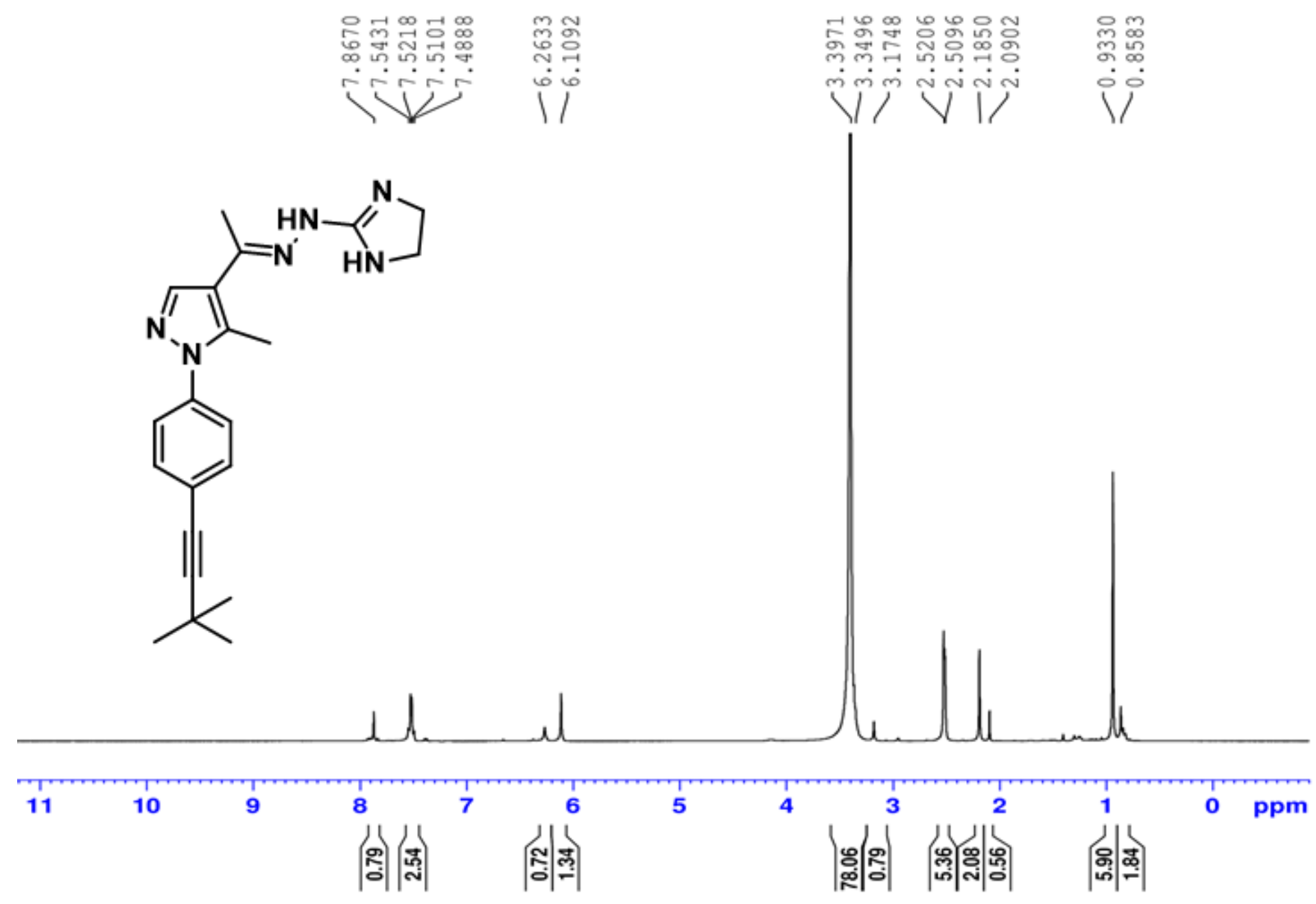

${ }^{1} \mathrm{H}$ NMR of compound 36 


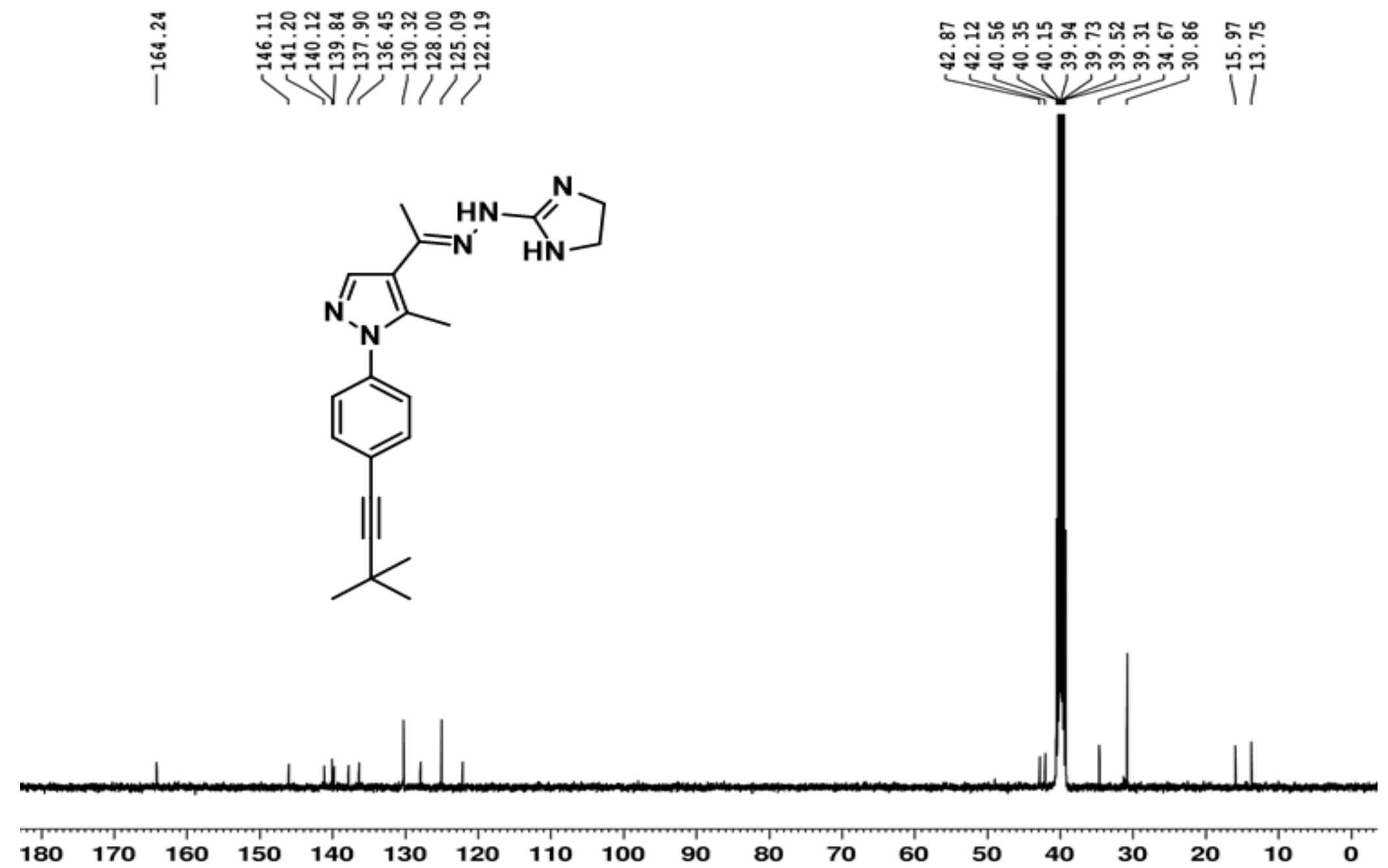

${ }^{13} \mathrm{C}$ NMR of compound 36 


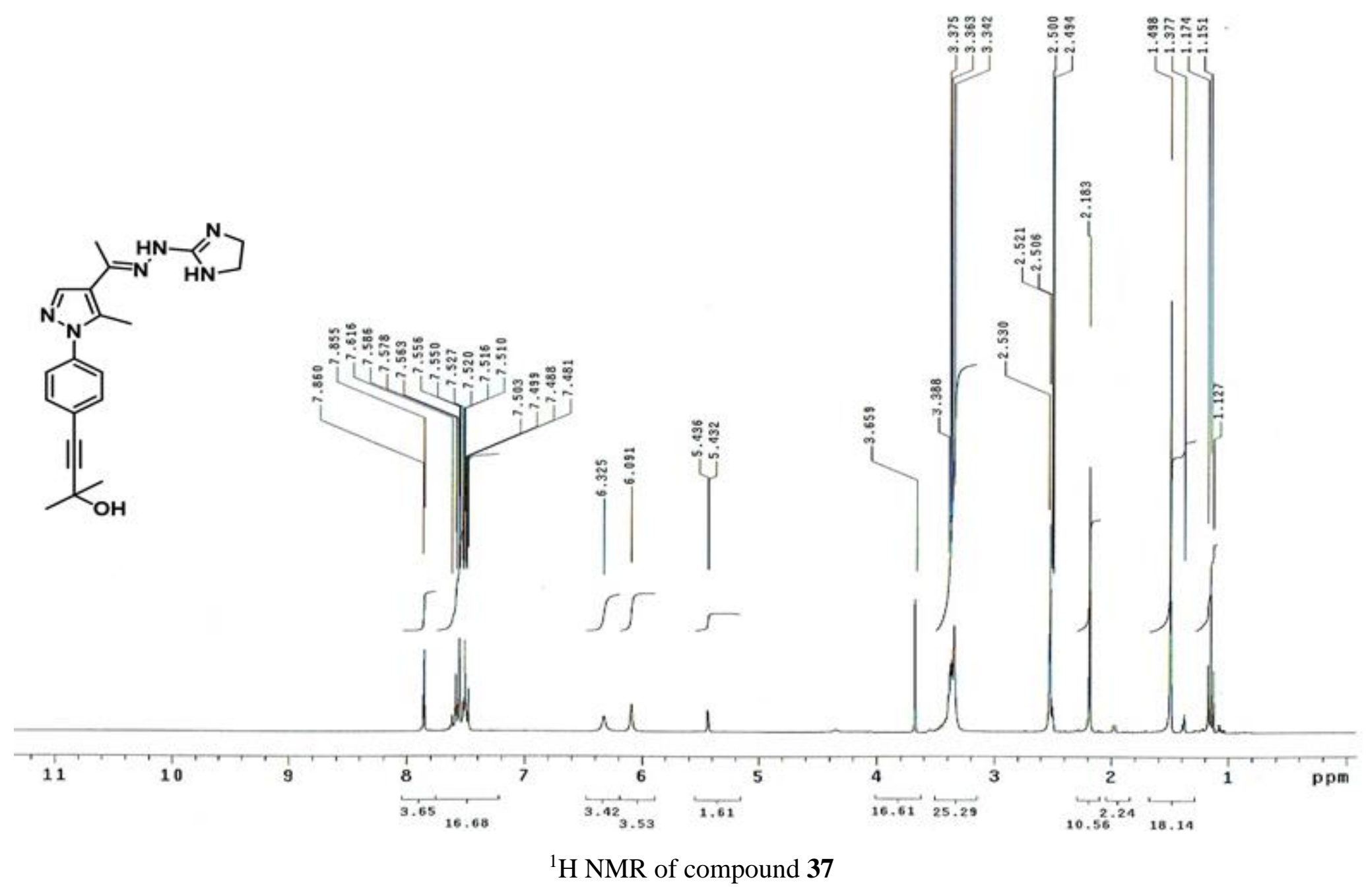




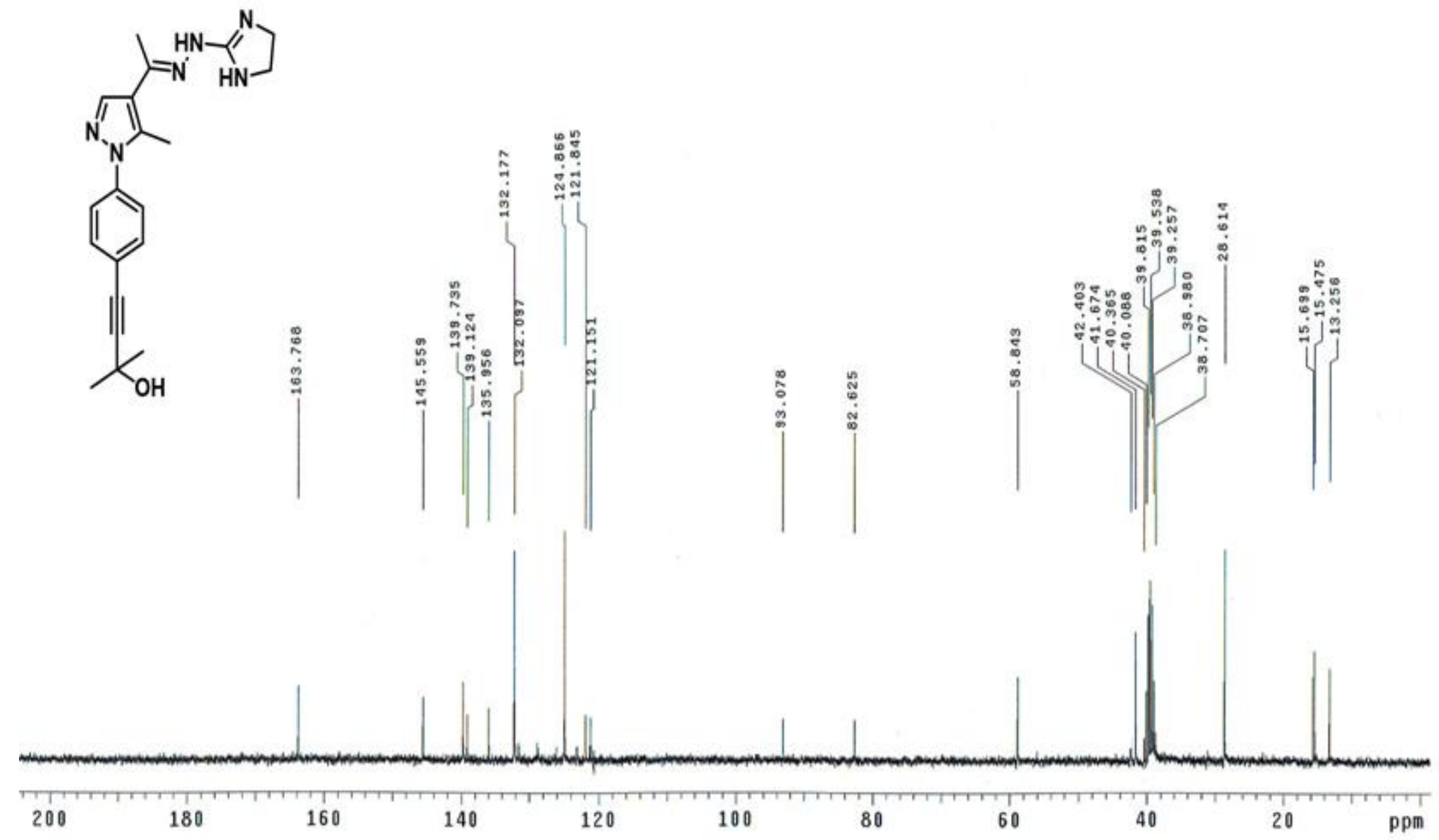

${ }^{13} \mathrm{C}$ NMR of compound $\mathbf{3 7}$ 


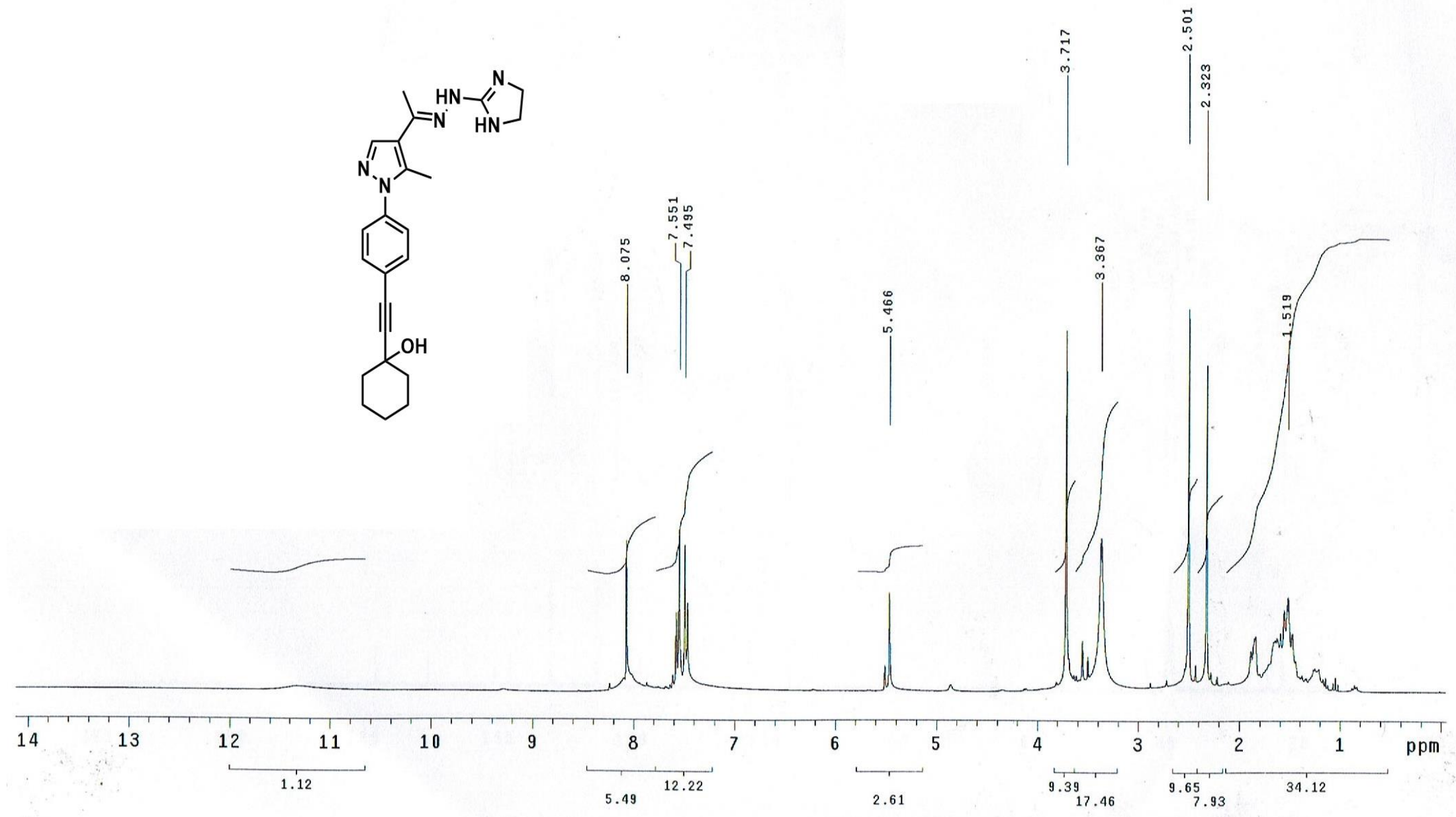

${ }^{1} \mathrm{H}$ NMR of compound 38 

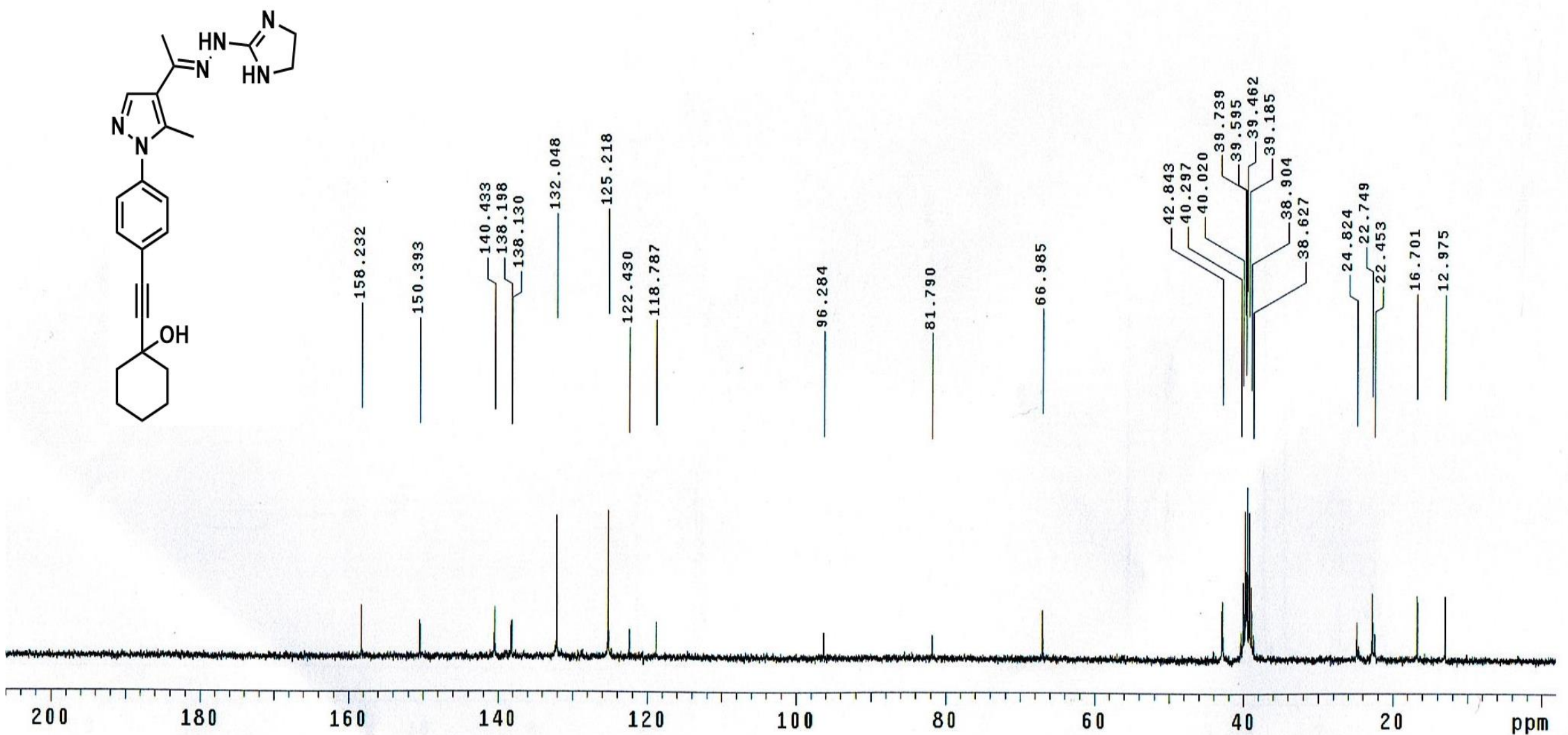

${ }^{13} \mathrm{C}$ NMR of compound 38 


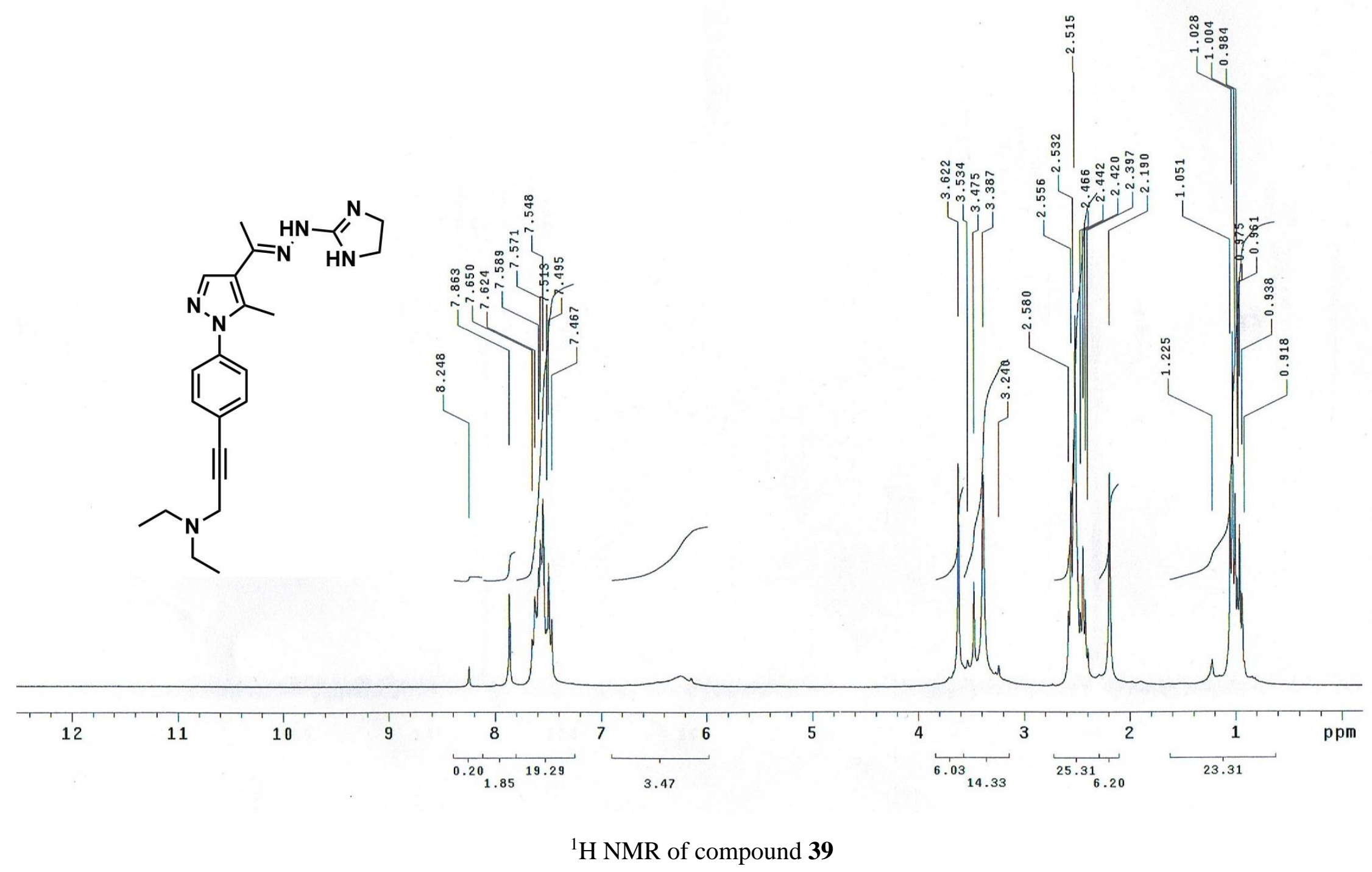



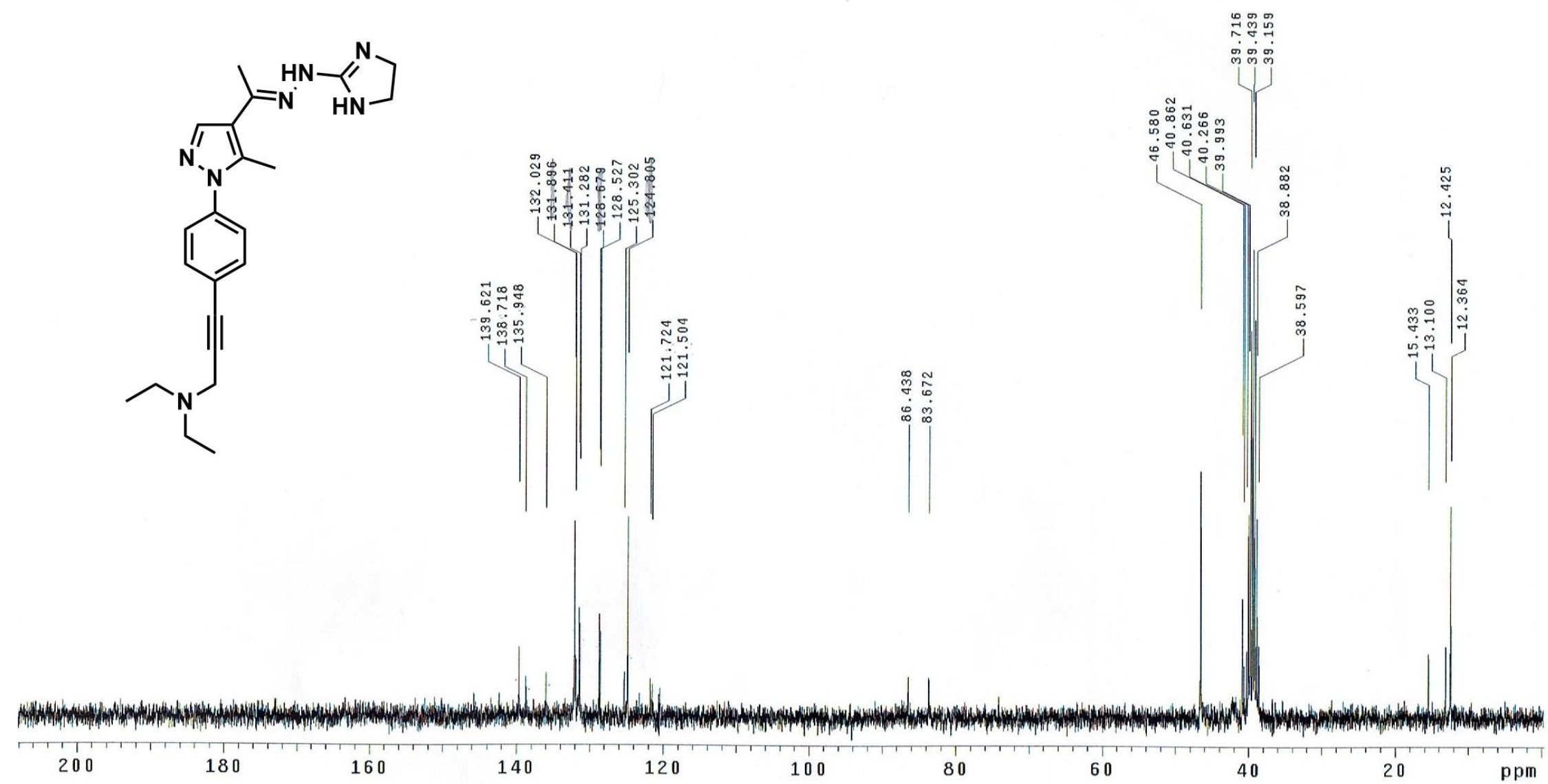

${ }^{13} \mathrm{C}$ NMR of compound 39 
HPLC analysis. The chromatographic analysis process was performed, at room temperature, using isocratic elution on BDS Hypersil C18 column ( $250 \times 4.6 \mathrm{~mm}$, $5 \mu \mathrm{m}$ particle size). The eluted mobile phase consists of acetonitrile: potassium dihydrogene phosphate, $\mathrm{pH} 7.8,(90: 10, \mathrm{v} / \mathrm{v})$. The mobile phase was degassed by a degasser then pumped at flow rate of $1.2 \mathrm{~mL} / \mathrm{min}$. UV detection was carried out at $254 \mathrm{~nm}$, and the injection volume was $20 \mu \mathrm{L}$. 


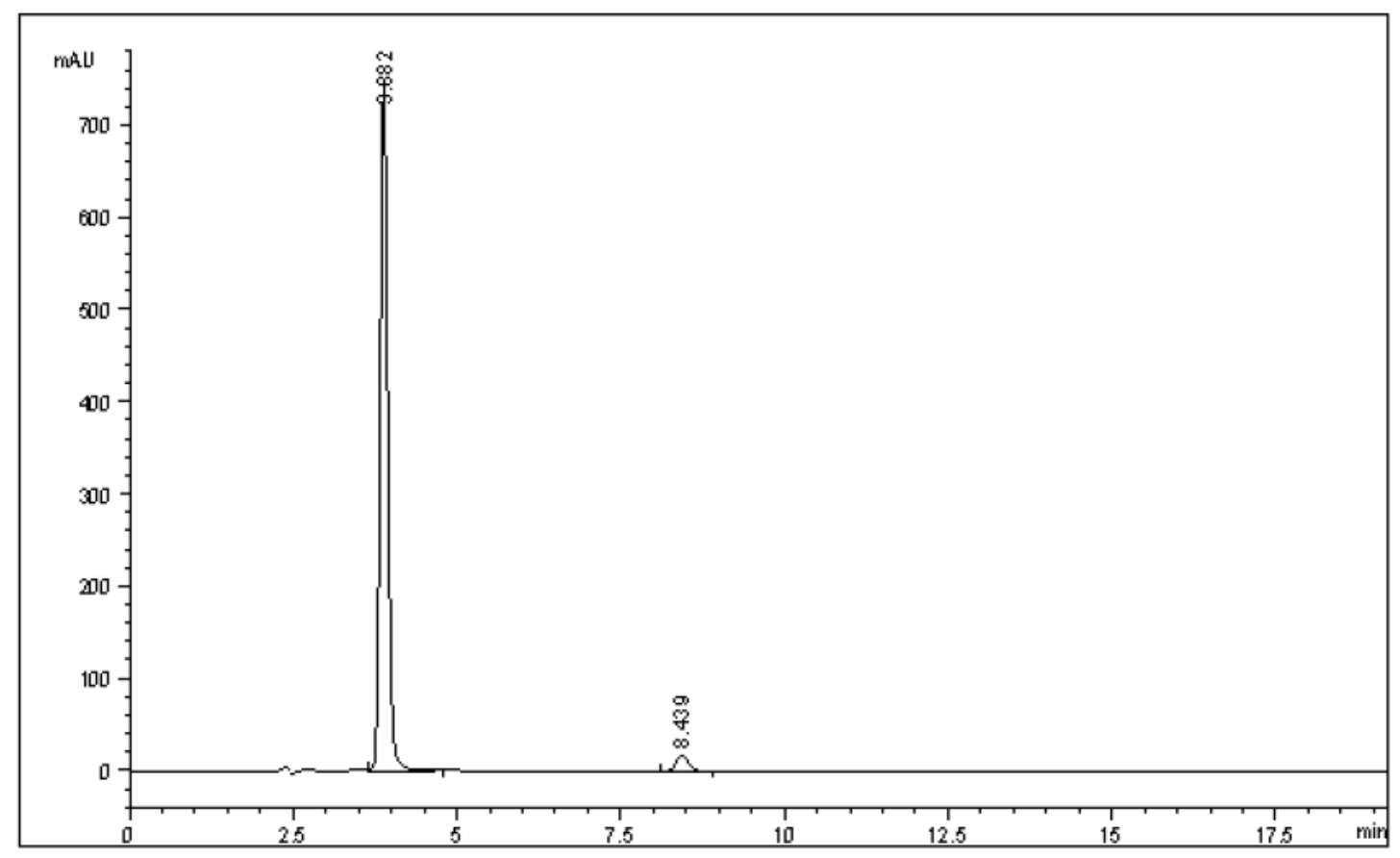

\section{Compound16}

\begin{tabular}{|c|c|c|c|c|c|}
\hline \multirow{2}{*}{$\begin{array}{c}\text { Peak } \\
\quad \#\end{array}$} & \multirow{2}{*}{$\begin{array}{l}\text { RetTime Type } \\
\text { [min] }\end{array}$} & \multirow{2}{*}{$\begin{array}{l}\text { Width } \\
\text { [min] }\end{array}$} & Area & Height & \multirow{2}{*}{$\begin{array}{l}\text { drea } \\
\text { 믐 }\end{array}$} \\
\hline & & & minU & [midJ & \\
\hline 1 & $3.882 \mathrm{VR}$ & 0.1256 & 6070.76855 & 745,44257 & 96.3435 \\
\hline 2 & $8.439 \mathrm{BB}$ & 0.2129 & 230.39958 & 16.75310 & 3.6565 \\
\hline Tota & : & & 6301.16814 & 762.19567 & \\
\hline
\end{tabular}




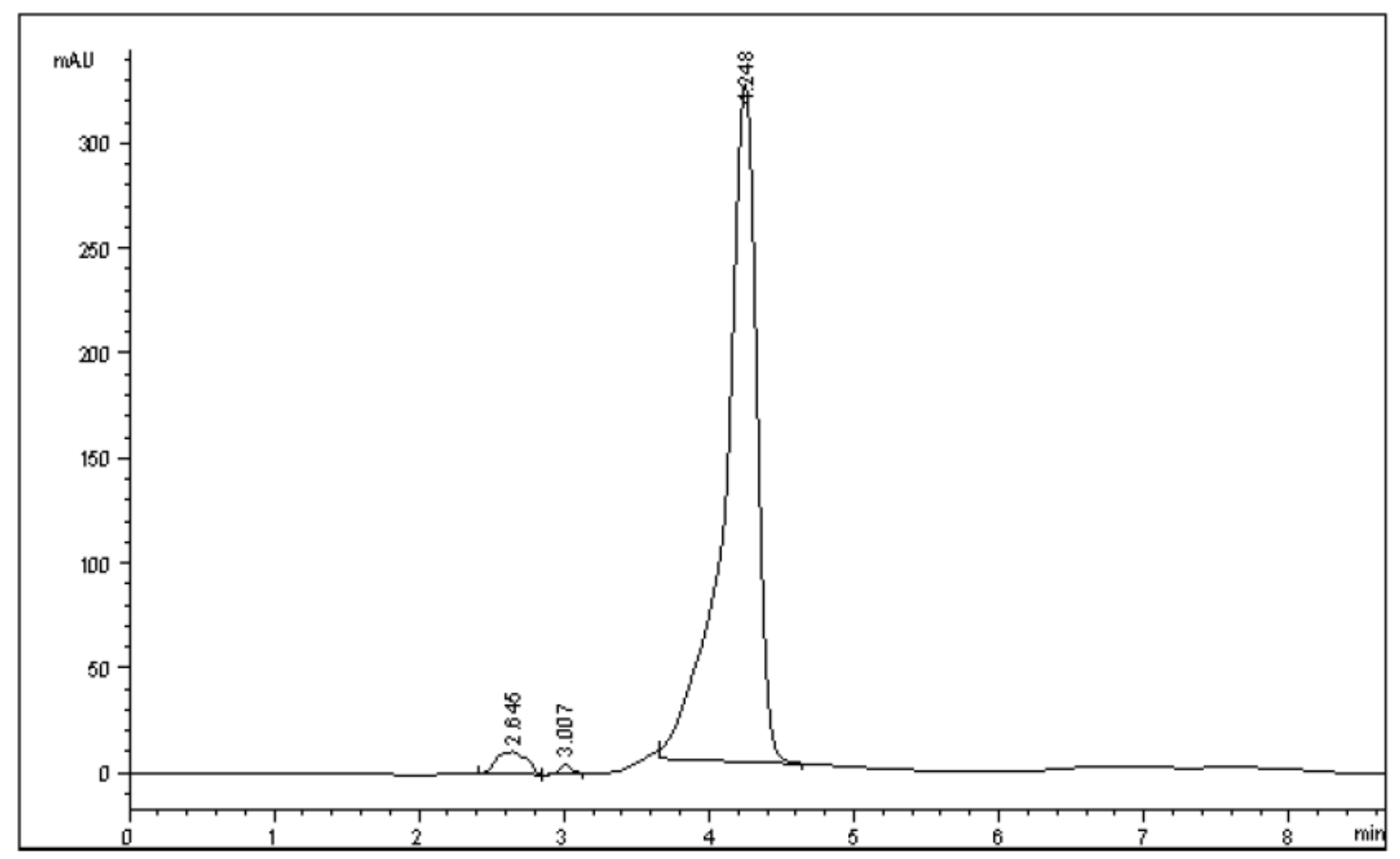

Compound 18

\begin{tabular}{|c|c|c|c|c|c|}
\hline \multirow{2}{*}{$\begin{array}{c}\text { Peal } \\
\# \\
\end{array}$} & \multirow{2}{*}{$\begin{array}{l}\text { RetTime Type } \\
\text { [min] }\end{array}$} & \multirow{2}{*}{$\begin{array}{l}\text { Width } \\
\text { [min] }\end{array}$} & Area & Height & \multirow{2}{*}{$\begin{array}{c}\text { Area } \\
\text { 믑 }\end{array}$} \\
\hline & & & $\mathrm{m}$. $\mathrm{AU}$ & [m.MU] & \\
\hline 1 & $2.645 \mathrm{BV}$ & 0.1864 & 152.19185 & 10.69512 & 2.9649 \\
\hline 2 & 3.007 VB & 0.0880 & 28.90110 & 4.77875 & 0.5630 \\
\hline 3 & $4.248 \mathrm{BB}$ & 0.2256 & 4952.05859 & 322.67239 & 96.4721 \\
\hline Total & : & & 5133.15154 & 338.14626 & \\
\hline
\end{tabular}




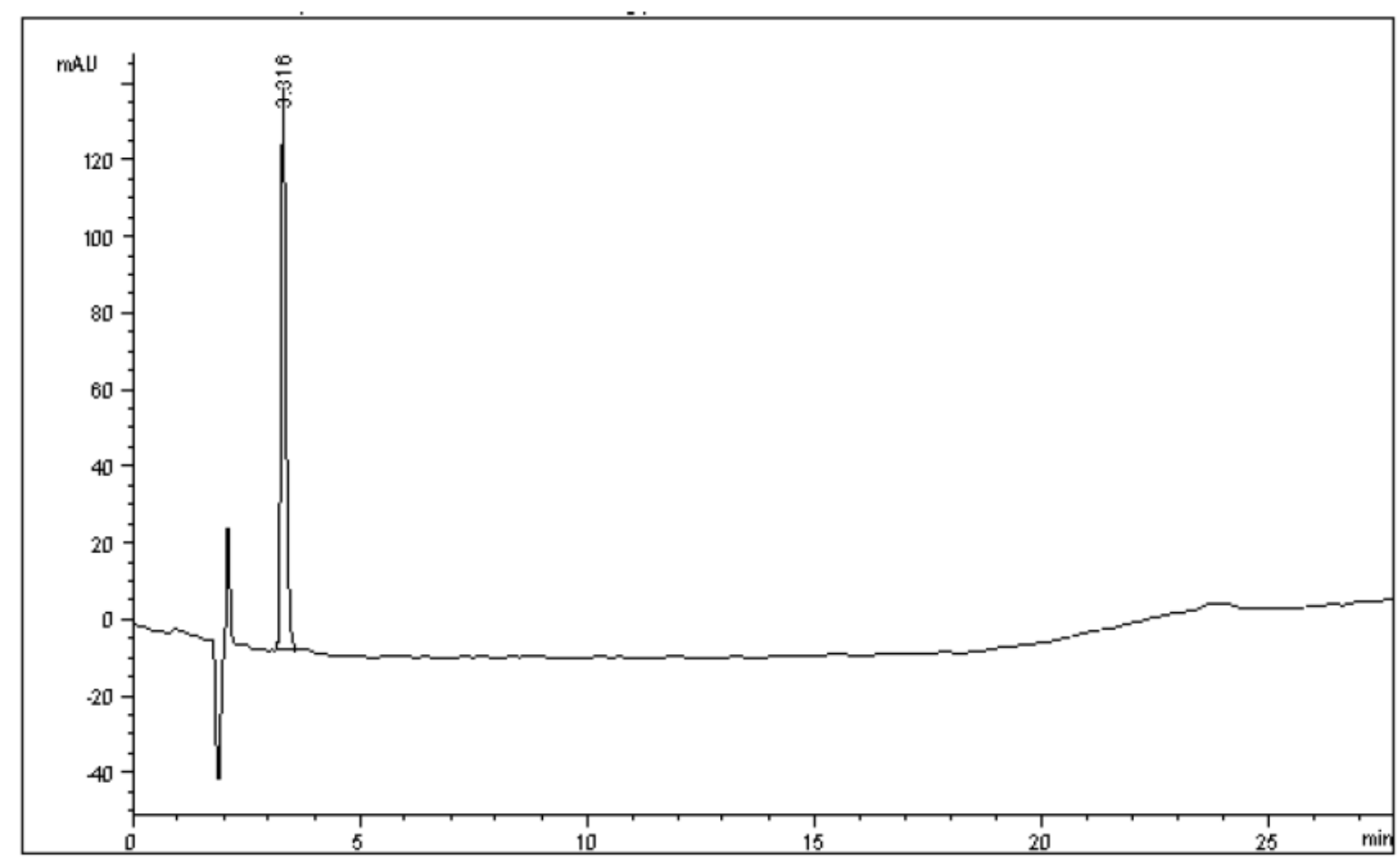

Compound 19

\begin{tabular}{|c|c|c|c|c|c|}
\hline \multirow{2}{*}{$\begin{array}{c}\text { Peaz } \\
\quad \#\end{array}$} & \multirow{2}{*}{$\begin{array}{l}\text { Ret Time Type } \\
\text { [min] }\end{array}$} & \multirow{2}{*}{$\begin{array}{l}\text { Width } \\
\text { [min] }\end{array}$} & Area & Height & \multirow{2}{*}{$\begin{array}{c}\text { Area } \\
\text { 믑 }\end{array}$} \\
\hline & & & mint & [midU & \\
\hline & 1. & ----- & |--------- & -ー-ー-ー-ー- & |-------- \\
\hline 1 & $3.316 \mathrm{BB}$ & 0.1152 & 1100.31958 & 146.62450 & 100.0000 \\
\hline Total & : & & 1100.31958 & 146.62450 & \\
\hline
\end{tabular}




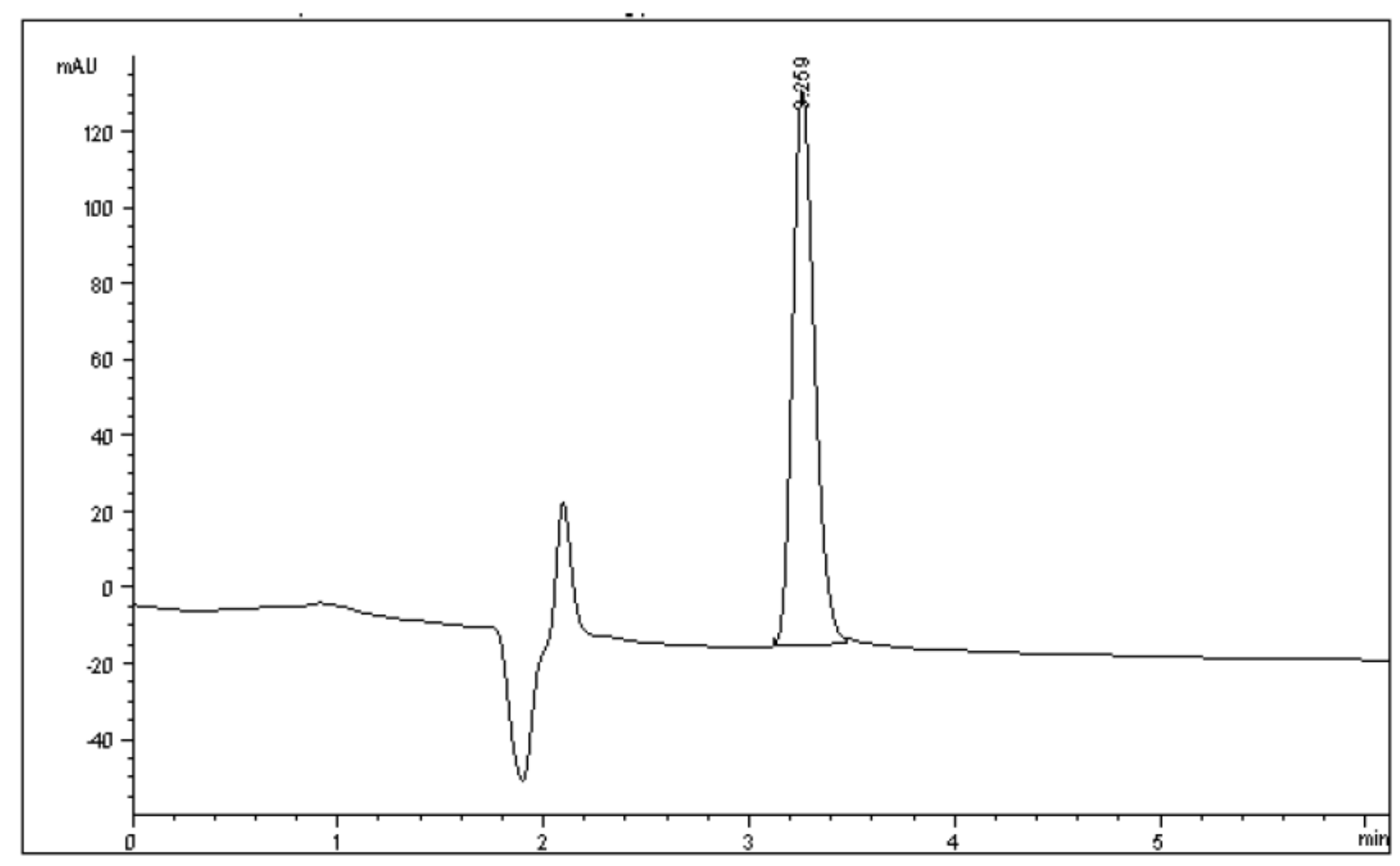

Compound 21

\begin{tabular}{|c|c|c|c|c|c|c|}
\hline \multirow{2}{*}{$\begin{array}{c}\text { Peak } \\
\#\end{array}$} & \multirow{2}{*}{$\begin{array}{l}\text { RetTime Type } \\
\text { [min] }\end{array}$} & \multirow{2}{*}{$\begin{array}{l}\text { Width } \\
\text { [min] }\end{array}$} & \multicolumn{2}{|c|}{ Area } & Height & \multirow{2}{*}{$\begin{array}{c}\text { Area } \\
\text { 믑 }\end{array}$} \\
\hline & & & misU & ${ }^{*} s$ & [m.mSJ & \\
\hline 1 & $3.259 \mathrm{BB}$ & 0.1126 & 1083 & 06824 & 146.26147 & 100.0000 \\
\hline $\cot$ & & & 1083 & 06824 & 146.26147 & \\
\hline
\end{tabular}




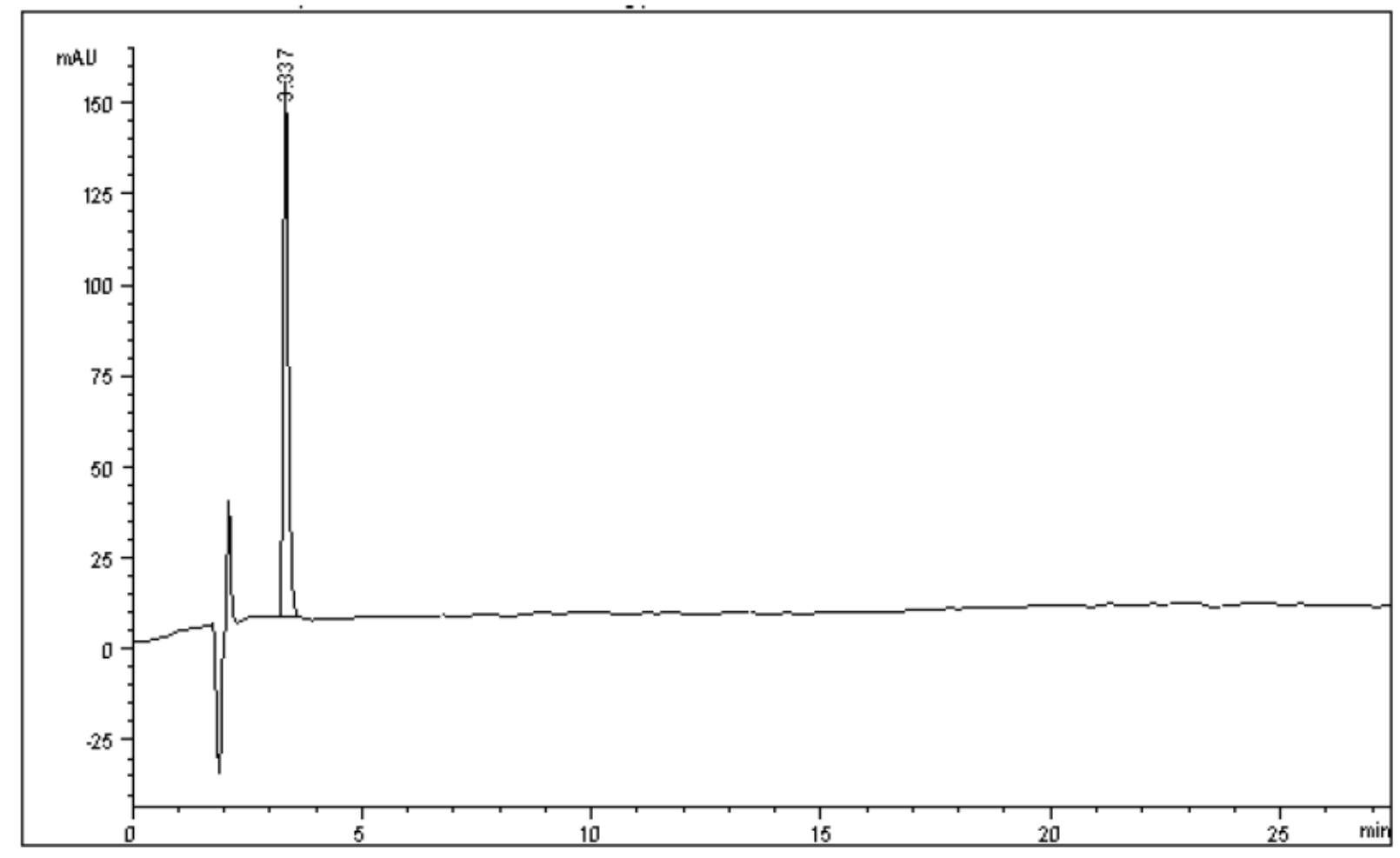

Compound 22

\begin{tabular}{|c|c|c|c|c|c|}
\hline Peak & RetTime Type & Width & Area & Height & hrea \\
\hline$\#$ & [min] & [min] & $\mathrm{m} \mathrm{mUU}$ & [m $\mathrm{m} \mathrm{EJ}$ & 몸 \\
\hline 1 & $3.337 \mathrm{BB}$ & 0.1137 & 1102.49670 & 147.05078 & 100.0000 \\
\hline Total & & & 1102.49670 & 147.05078 & \\
\hline
\end{tabular}



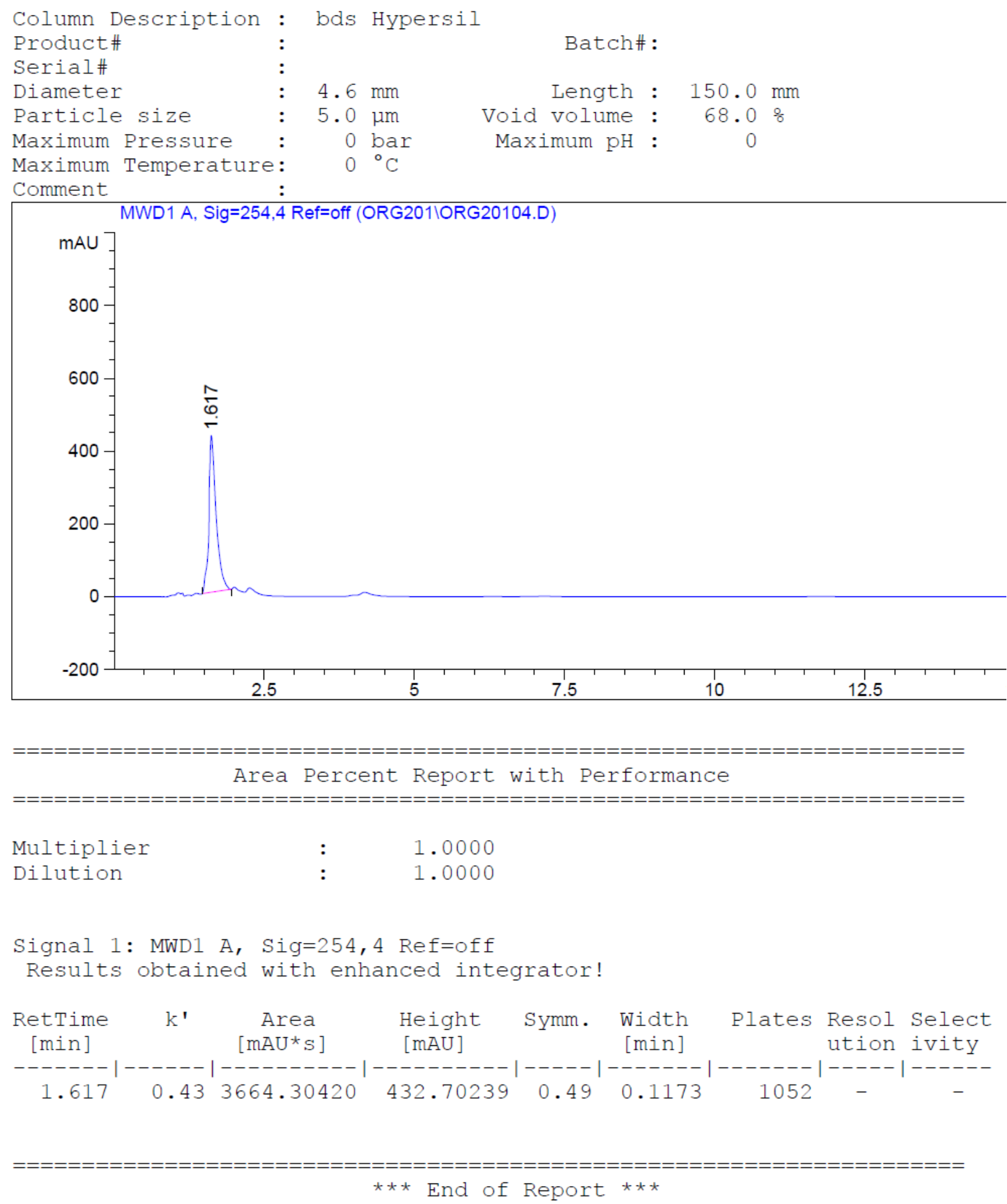

\section{Compound 23}



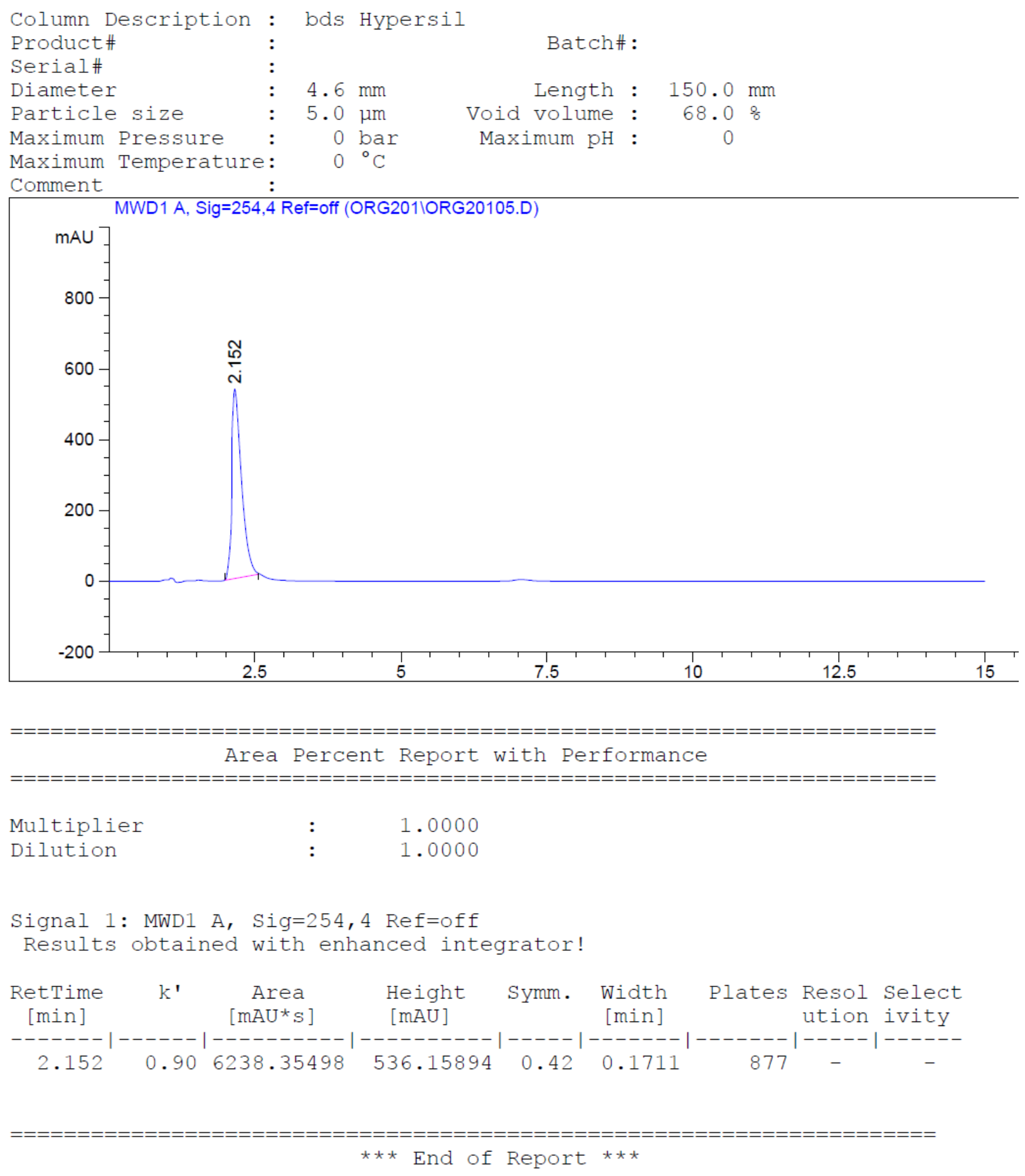

\section{Compound 24}




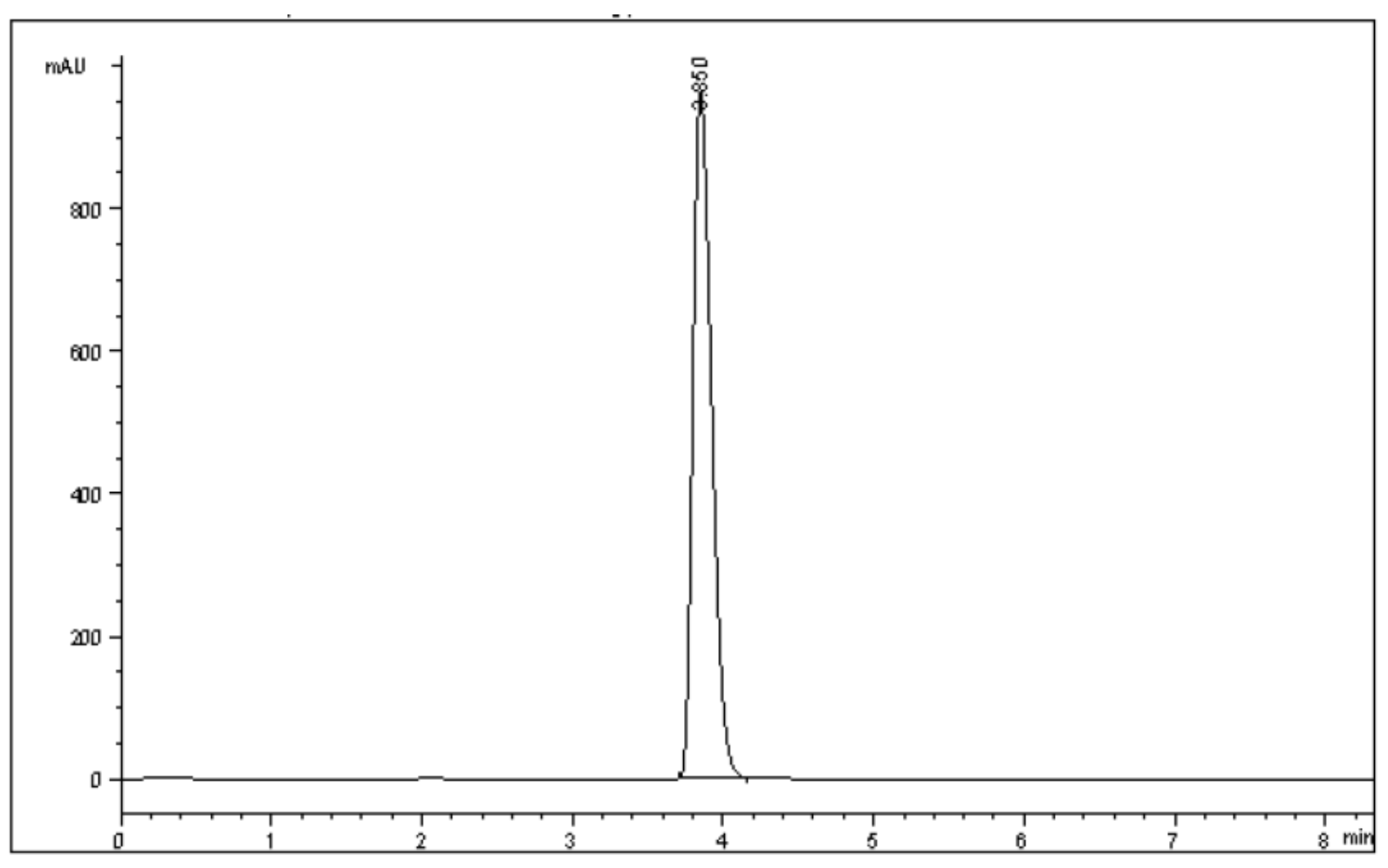

\section{Compound 25}

\begin{tabular}{|c|c|c|c|c|c|c|}
\hline \multirow{2}{*}{$\begin{array}{c}\text { Peak } \\
\#\end{array}$} & \multirow{2}{*}{$\begin{array}{l}\text { RetTime Type } \\
\text { [min] }\end{array}$} & \multirow{2}{*}{$\begin{array}{l}\text { Wiidth } \\
\text { [min] }\end{array}$} & \multicolumn{2}{|c|}{ Area } & Height & \multirow{2}{*}{$\begin{array}{c}\text { Area } \\
\text { 몹 }\end{array}$} \\
\hline & & & $\mathrm{mBU}$ & ${ }^{*} 3$ & [m.2JJ & \\
\hline 1 & $3850 \mathrm{BR}$ & 0.1360 & 8358. & 92090 & 965.17297 & 100, 10000 \\
\hline Tot & : & & 8358. & 92090 & 965.17297 & \\
\hline
\end{tabular}




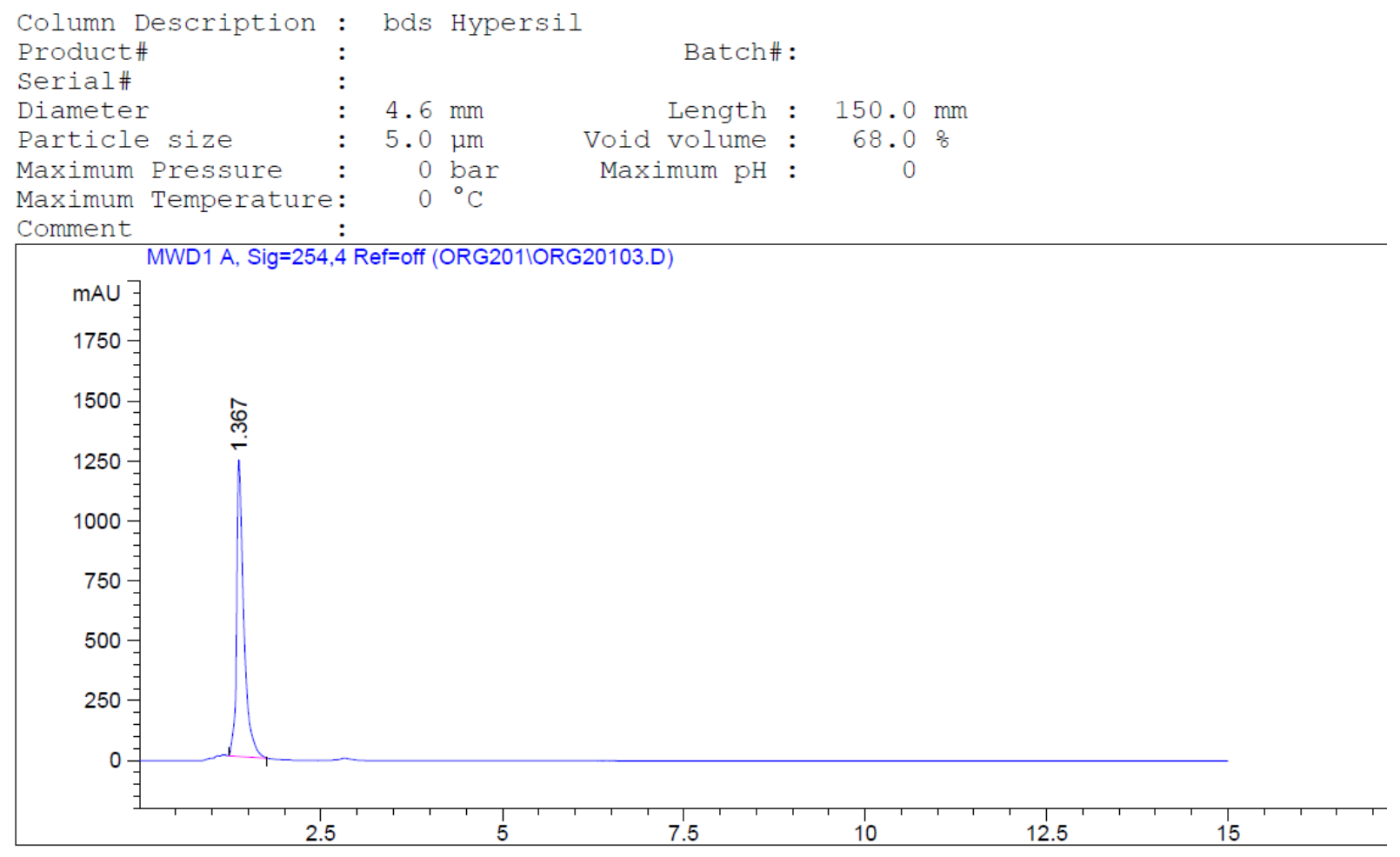

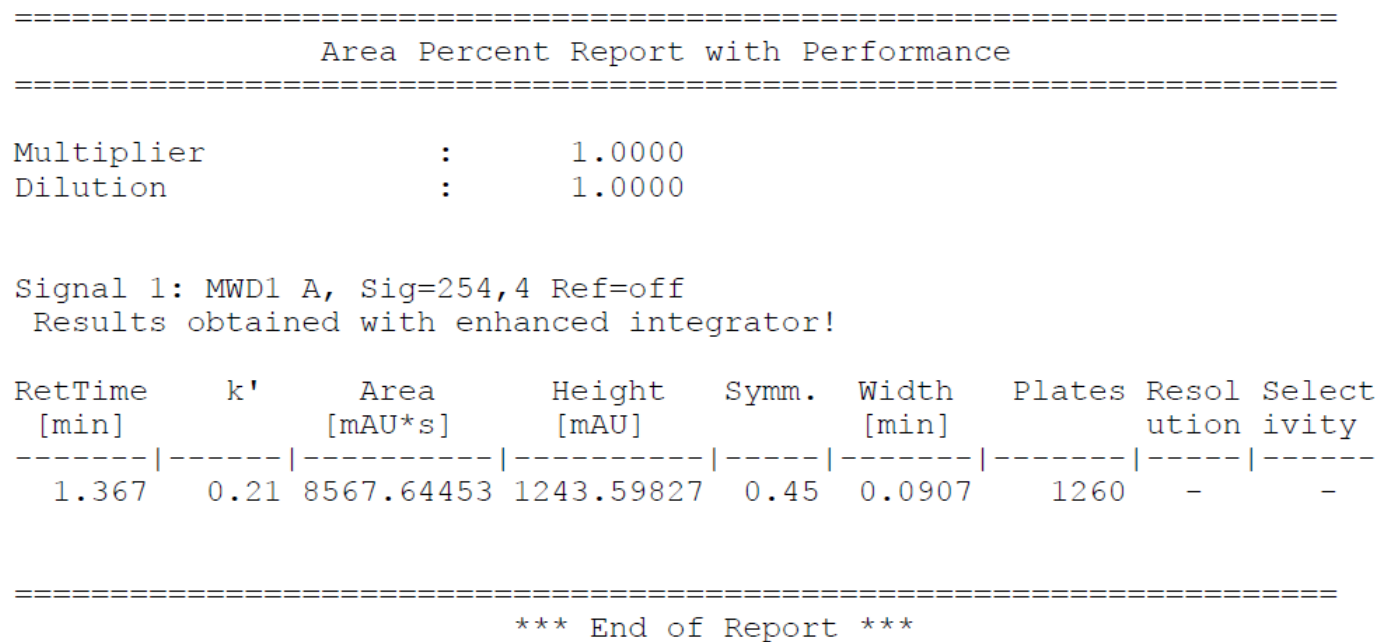

\section{Compound 26}



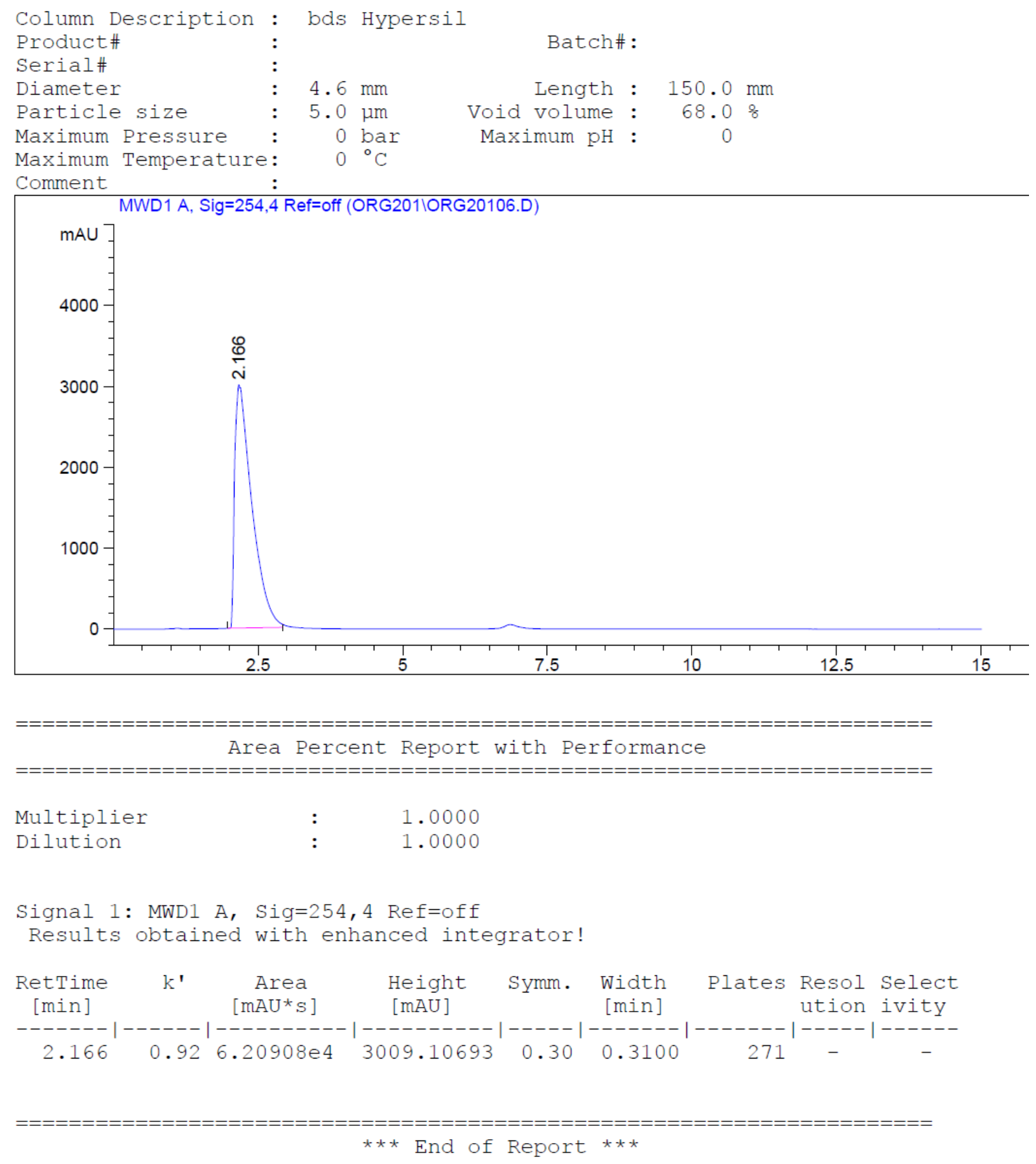

\section{Compound 29}




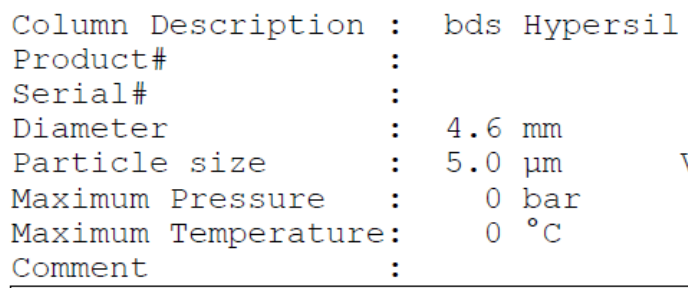




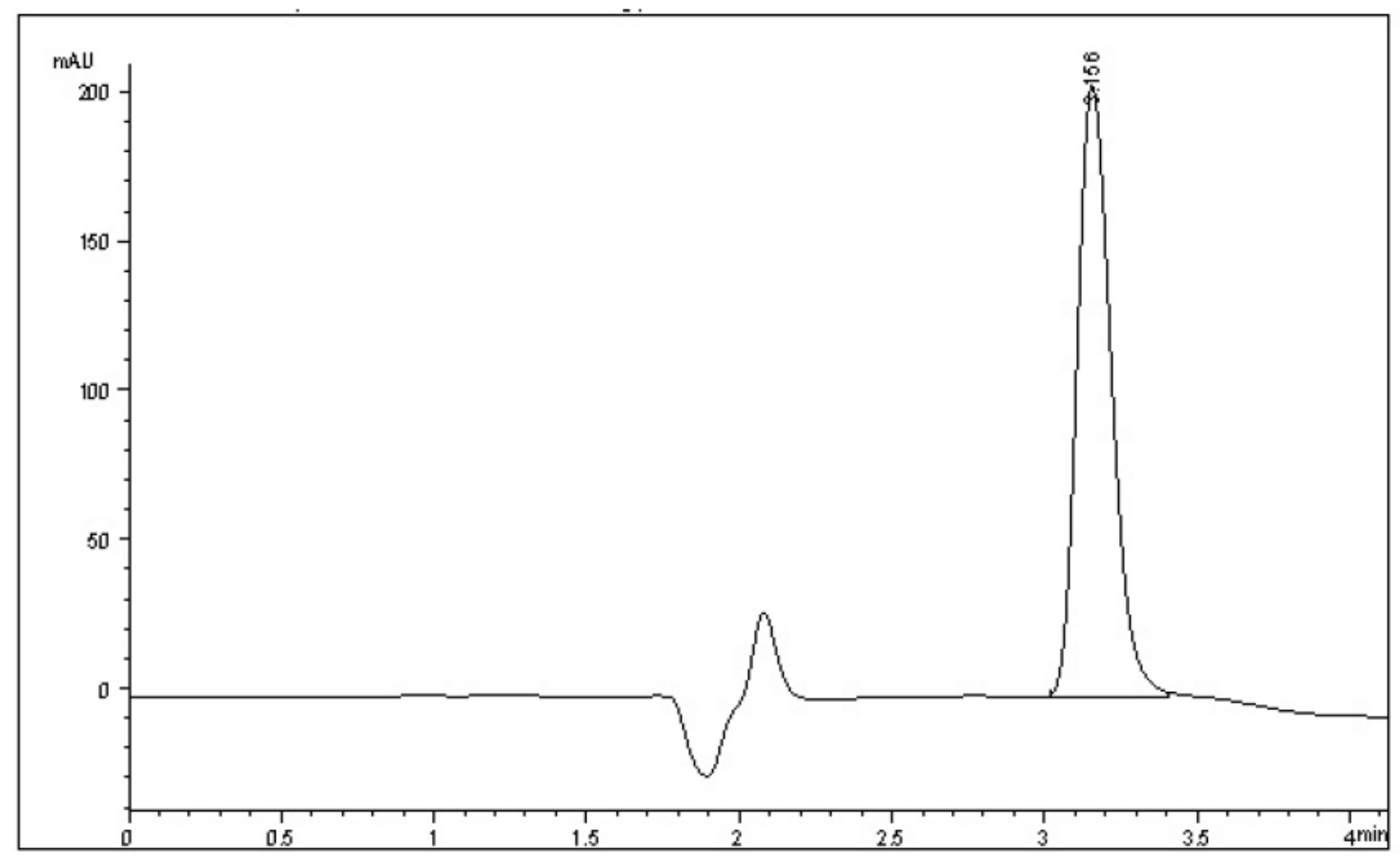

Compound 31

\begin{tabular}{|c|c|c|c|c|c|c|}
\hline Peak & Ret Time Type & Width & Ar & ea & Height & Area \\
\hline$\#$ & [min] & [min] & midU & ${ }^{*} \mathrm{~S}$ & [maSJ & 믑 \\
\hline 1 & $3.156 \mathrm{BB}$ & 0.1213 & 1595. & 57776 & 205.14331 & 100.0000 \\
\hline Total & & & 1595. & 57776 & 205.14331 & \\
\hline
\end{tabular}




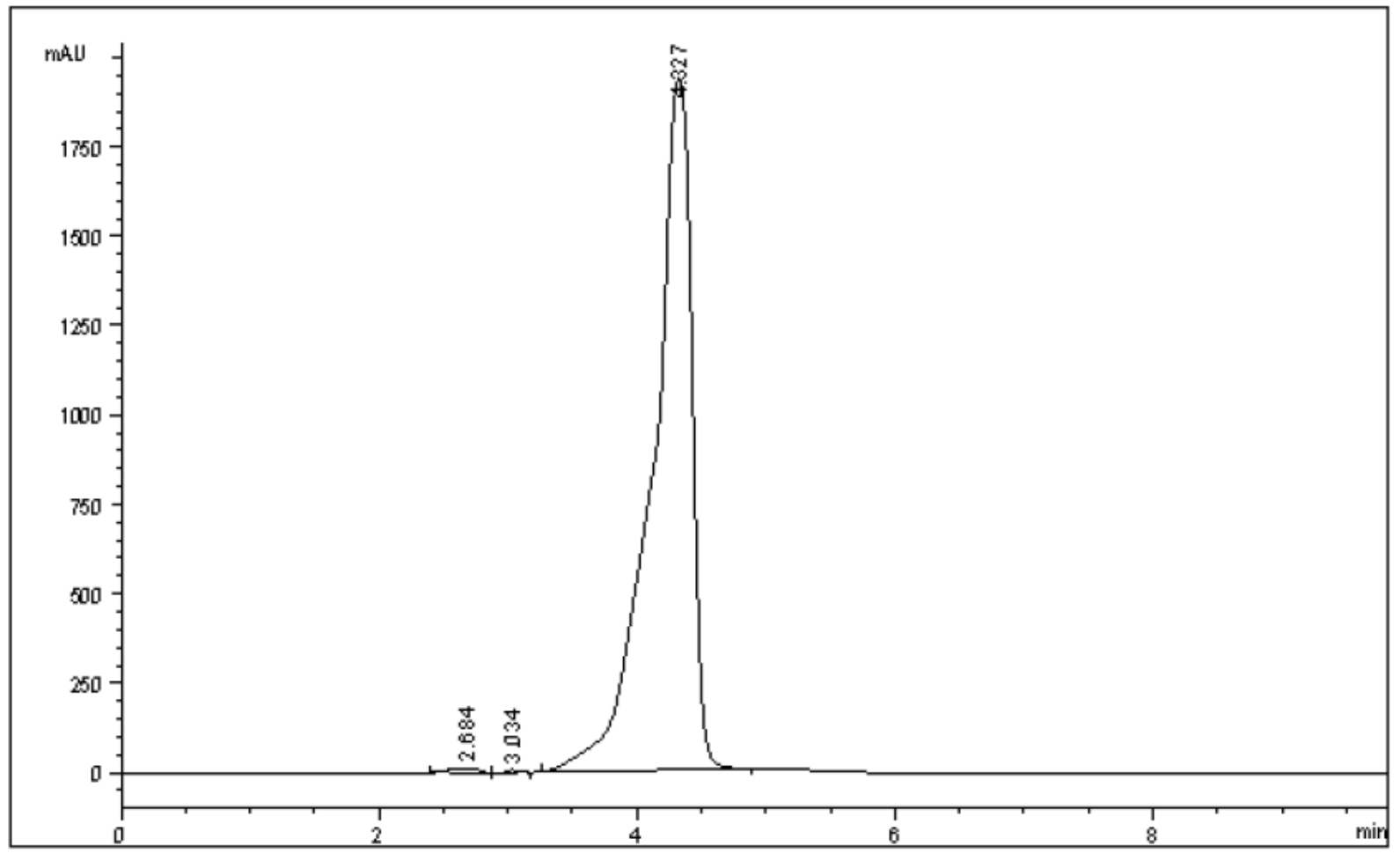

Compound 32

\begin{tabular}{|c|c|c|c|c|c|}
\hline \multirow{3}{*}{$\begin{array}{c}\text { Peak } \\
\#\end{array}$} & \multirow{2}{*}{$\begin{array}{l}\text { Ret Time Type } \\
\text { [min] }\end{array}$} & \multirow{2}{*}{$\begin{array}{l}\text { Width } \\
\text { [min] }\end{array}$} & Area & Height & \multirow{2}{*}{$\begin{array}{l}\text { Area } \\
\text { 몹 }\end{array}$} \\
\hline & & & $\mathrm{m} \mathrm{mU}$ & [miJJ & \\
\hline & . & 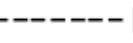 & -- & |--- & - \\
\hline 1 & $2.684 \mathrm{BV}$ & 0.2057 & 190.24394 & 11.79320 & 0.4629 \\
\hline 2 & $3.034 \mathrm{VB}$ & 0.0833 & 42.83502 & 7.75782 & 0.1042 \\
\hline 3 & $4.327 \mathrm{BB}$ & 0.3076 & $4.08665 \mathrm{e} 4$ & 1934.97852 & 99.4329 \\
\hline Tot & : & & $4.10995 \mathrm{e} 4$ & 1954.52954 & \\
\hline
\end{tabular}




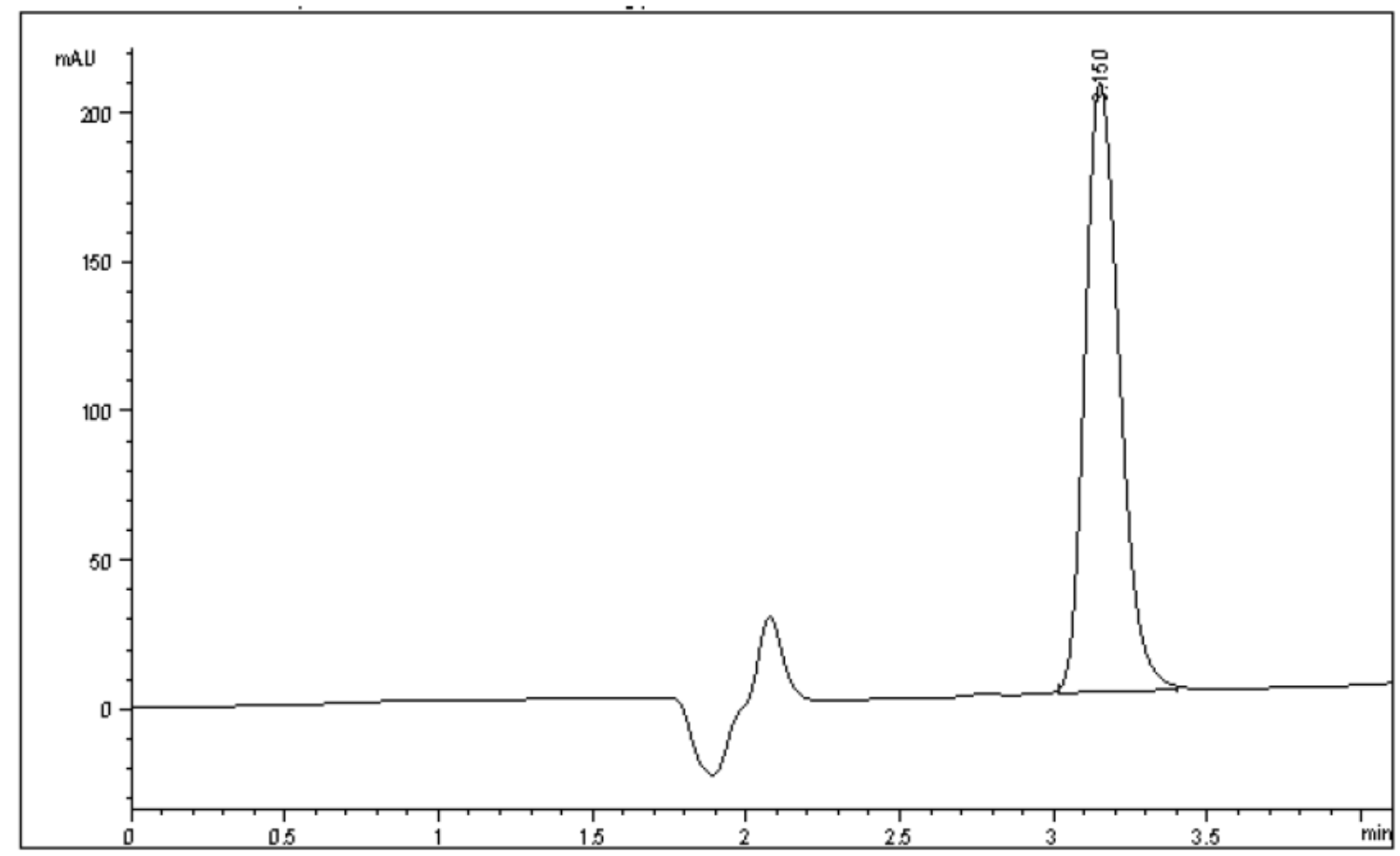

Compound 34

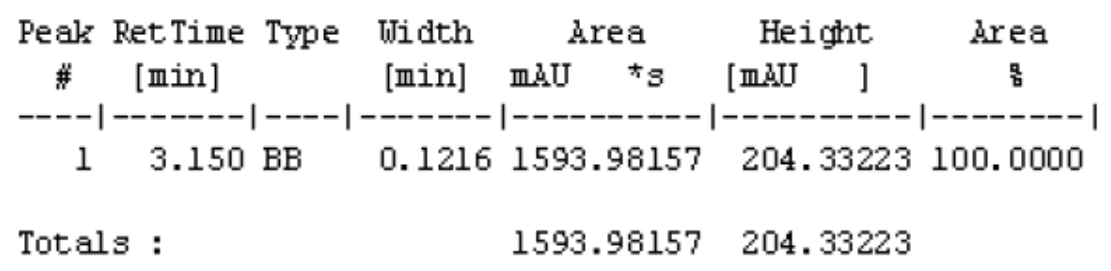

\section{References}

1. Hagras, M.; Abutaleb, N. S.; Ali, A. O.; Abdel-Aleem, J. A.; Elsebaei, M. M.; Seleem, M.

N.; Mayhoub, A. S. Naphthylthiazoles: Targeting Multidrug-Resistant and Intracellular Staphylococcus Aureus with Biofilm Disruption Activity. ACS Infect Dis 2018, 4, 1679-1691.

2. Mohammad, H.; Younis, W.; Chen, L.; Peters, C. E.; Pogliano, J.; Pogliano, K.; Cooper, B.; Zhang, J.; Mayhoub, A.; Oldfield, E.; Cushman, M.; Seleem, M. N. Phenylthiazole Antibacterial Agents Targeting Cell Wall Synthesis Exhibit Potent Activity in Vitro and in Vivo against Vancomycin-Resistant Enterococci. J Med Chem 2017, 60, 2425-2438. 
3. Thangamani, S.; Younis, W.; Seleem, M. N. Repurposing Celecoxib as a Topical Antimicrobial Agent. Frontiers in microbiology 2015, 6, 750.

4. Kotb, A.; Abutaleb, N. S.; Seleem, M. A.; Hagras, M.; Mohammad, H.; Bayoumi, A.; Ghiaty, A.; Seleem, M. N.; Mayhoub, A. S. Phenylthiazoles with Tert-Butyl Side Chain: Metabolically Stable with Anti-Biofilm Activity. Eur J Med Chem 2018, 151, 110-120.

5. Desai, J.; Wang, Y. D.; Wang, K. D.; Malwal, S. R. D.; Oldfield, E. Isoprenoid Biosynthesis Inhibitors Targeting Bacterial Cell Growth. ChemMedChem 2016, 11, 2205-2215. 